\title{
COMPÓSITO DE COLÁGENO COM SILICATO E HIDROXIAPATITA COMO MATERIAL PARA ENDODONTIA.
}

\author{
Dissertação apresentada ao Programa de Pós- \\ Graduação Interunidades em Bioengenharia - \\ Escola de Engenharia de São Carlos / Faculdade de \\ Medicina de Ribeirão Preto / Instituto de Química \\ de São Carlos da Universidade de São Paulo, como \\ parte dos requisitos para obtenção do título de \\ mestre em Bioengenharia.
}

\section{Orientador: Prof ${ }^{\circ}$. Dr. Gilberto Goissis}

\section{São Carlos}




\section{DEDICATÓRIAS}

Em primeiro lugar a Deus que me deu força, perseverança, saúde e sabedoria para acreditar que tudo é possível... Basta pedir, acreditar e agir para sua glória, por intermédio de Nossa Senhora...

Aos meus pais Miguel e Maria pelo dom da vida e pelo apoio e orientação nos momentos difíceis. Sacrificaram-se muitas vezes por minha causa e deixando os seus sonhos para mais tarde dando "tempo ao tempo".

À minha querida filha Monique que muitas vezes é amada a distância... Por eu estar ocupado com o trabalho e o estudo...

À minha ex-esposa Vânia pela amizade...

À Lúcia pela força espiritual e carinho...

Ao meu irmão José Carlos (Zezinho) e Aux. pelo incentivo e companheirismo Aos meus sobrinhos Mariana e Marquinho...

Aos meus amigos verdadeiros... 


\section{AGRADECIMENTOS}

Ao Profo. Dr. Gilberto Goissis, pela orientação, oportunidade, confiança e conhecimentos profissionais compartilhados.

À secretária Janete pelo companheirismo e dedicação ao trabalho.

Ao José Milton, Caio e Raquel pela amizade - São Carlos SP

À Virgínia, Ézer e Glauco pelos serviços, favores, ensinamentos e companheirismos durante os trabalhos no laboratório.

Aos funcionários e amigos do departamento de Química

Aos Funcionários da Biblioteca do IQSC, IFSC e EESC.

Ao Professores da Bioengenharia João Manuel Domingos de Almeida Rollo, José Carlos Pereira, Luiz Romariz Duarte, José Marcos Alves, Orivaldo Lopes da Silva e Ana Maria de Guzzi Plépis pela transmissão de conhecimentos.

Aos Professores da UNESP de Araraquara Profa. Elisabeth Loshchagin Pizzolitto e esposo Prof ${ }^{o}$ Pizzolitto, pelos conhecimentos transmitidos.

Aos funcionários Nelson e Mário, aos alunos e amigos da Bioengenharia, pelo companheirismo e amizade.

Aos muitos amigos de São Carlos SP, Araraquara SP e Campo Grande MS que muitas vezes distantes continuam incentivando meus trabalhos e conquistas...

Aos amigos da ABO/MS e CRO/MS

Aos amigos da Igreja de $N^{a} S^{a}$ Aparecida em Campo Grande MS

Ao Pe. Luciano e Pe. Pedro

Aos amigos da Igreja São João Batista da Coophasul

Aos Freis da MFMT

Aos amigos da UNIDERP

Aos amigos do SIOMS

Aos amigos da ABENO/MS

Aos amigos cirurgiões dentistas e protéticos...

Aos amigos músicos e cantores...

Aos meus pacientes por confiarem nos meus conhecimentos para a concretização deste trabalho e crescimento profissional. 
"Nada te perturbe.

Nada te espante.

Tudo passa.

Só Deus não muda.

A paciência tudo alcança.

Quem Deus tem, nada lhe falta!

Só Deus basta!”

(Santa Therezinha) 


\section{RESUMO}

E’GUES, M. A. M. Compósito de Colágeno com silicato e hidroxiapatita como material para Endodontia, 2005. Dissertação (Mestrado) - Programa de Pós Graduação Interunidades em Bioengenharia; Escola de Engenharia de São Carlos, Faculdade de Medicina de Ribeirão Preto, Instituto de Química de São Carlos, USP.

Este trabalho teve como objetivo preparar e caracterizar um compósito de colágeno com silicato e hidroxiapatita a ser possivelmente utilizado para capeamento pulpar direto e em pulpotomia como material endodôntico em prevenção ao tratamento radical de canais radiculares que em virtude de suas anatomias dificultam a utilização de biomateriais no interior dos mesmos. Embora materiais para este fim estejam disponíveis no mercado, na maioria dos casos não são isentos de agressão na zona do reparo. O colágeno utilizado foi do tipo I na forma aniônica que foi misturado com silicato (cimento Portland branco) e hidroxiapatita em proporções variadas. Os materiais obtidos foram caracterizados por técnicas de calorimetria exploratória diferencial (DSC), termogravimetria (TG), microscopia eletrônica de varredura (MEV), espectrometria de dispersão de energia de Raios-X (EDX) e espectroscopia na região do infravermelho (FTIR). A presença de colágeno no compósito foi demonstrada por transições térmicas típicas daquelas encontradas para o colágeno do tipo I $\left(\approx 48^{\circ} \mathrm{C}\right)$, independentemente da proporção utilizada, e também por $\mathrm{MEV}$, onde as fibras colagênicas também puderam ser observadas interligando as partículas de silicato. Em função das quantidades de colágeno utilizadas, a composição química dos compósitos foi praticamente aquela descrita para o silicato inicial utilizado. Estes resultados mostraram que a estrutura da matriz colagênica nos compósitos estudados não foi alterada, uma característica importante para a utilização dos materiais propostos na endodontia objetivando uma reparação dos tecidos envolvidos de uma forma "mais natural”.

Palavras - chave: Compósito de colágeno - Hidroxiapatita - Endodontia 


\section{ABSTRACT}

EGUES, M. A. M. Collagen composite with silicate and hydroxyapatite as material for Endodontic applications, 2005 Dissertation (Master’s) - Programa de Pós Graduação Interunidades em Bioengenharia; Escola de Engenharia de São Carlos, Faculdade de Medicina de Ribeirão Preto, Instituto de Química de São Carlos, USP.

In this work was prepared and characterized collagen composites with silicate and hydroxyapatite for pulp capping; post pulpotomy usage, as endodontic material. Even though materials for this purpose are available, in most case they suffer degradation in the repair zone when. Was used type I collagen in the form anionic mixed with silicate (White Portland cement) and hydroxyapatite in various proportions. The materials were characterized by standard differential scanning calorimetry (DSC), thermogravimetry (TG), scanning electronic microscopy (SEM) and infrared spectroscopy (FTIR), Energy Dispersion X-Ray (EDX). The presence of the collagen in the composite was checked via the thermal transitions typical for collagen type I $(\approx$ $48^{\circ} \mathrm{C}$ ), independently of the proportion used and also via $\mathrm{MEV}$, in which the collagenic fibers could also be seen interconnecting the silicate particles. For the amounts of collagen used, we find the chemical composition of the composites is essentially the same as that of the silicate we started with. This results showed that the structure of the collagenic matrix in the composite studied is not altered - an important feature for the use of the proposed materials in endodontic applications aiming at repairing the relevant tissues in a "more natural way".

Keywords: Collagen composite - hydroxiapatite - Endodontic 


\section{LISTA DE FIGURAS}

FIGURA 1. Desenho esquemático de um dente humano com suas estruturas internas e adjacentes

FIGURA 2. Relação entre tamanho de microrganismos e túbulos dentinários .......... 21

FIGURA 3. Alvéolos dentais de maxila ……....................................................... 23

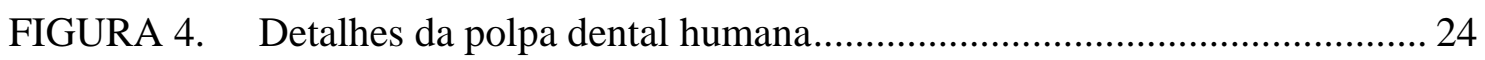

FIGURA 5. Variedade de condutos radiculares ..................................................... 25

FIGURA 6. Corte transversal de raiz de molar evidenciando o Istmo ....................... 26

FIGURA 7. Corte transversal de raízes de molar evidenciando a furca e o forame do canal acessório, indicado pela seta (aumento 20x).

FIGURA 8. O forame visto em A, aumentado 1.000x. O canal mede 35 micra, abrindo-se para 60 micra na superfície ................................................ 27

FIGURA 9. Técnica de capeamento pulpar direto.................................................... 29

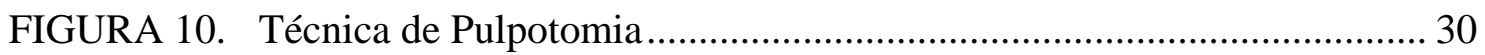

FIGURA 11. Representação esquemática das estruturas de colágeno......................... 38

FIGURA 12. Organização estrutural das moléculas de tropocolágeno de acordo com o modelo de Smith, para a formação da microfibrila: a) modela quarto alternado pentafibrilar; b) periodicidade da microfibrila.

FIGURA 13. Esquema representativo da parte experimental

FIGURA 14. (a) sistema de moldagem dos cimentos $\left(\mathrm{A}_{1}\right.$ e $\mathrm{A}_{2}=$ placas lisas inferior e superior, respectivamente; $\mathrm{B}=$ placa perfurada; $\mathrm{C}=$ pino removedor; (b) corpos de prova obtidos

FIGURA 15. Esquema representativo da hidrólise alcalina dos grupos carboxiamidas

FIGURA 16. Espectroscopia na região do infravermelho para o colágeno 24horas.

FIGURA 17. Curva de Calorimetria Exploratória Diferencial obtida da amostra de Colágeno porcino (24 horas).

FIGURA 18. Curva Termogravimétrica da amostra de Cimento Portland Branco, obtido comercialmente

FIGURA 19. Espectroscopia na região do infravermelho para o cimento Portland branco obtido comercialmente.... 
FIGURA 20. Curva Termogravimétrica da amostra de Hidroxiapatita sintetizada..... 59

FIGURA 21. Micrografia eletrônica de varredura da amostra da amostra (Cimento Portland Branco + Água) em aumento de $500 \mathrm{x}$

FIGURA 22. Micrografia eletrônica de varredura da amostra da amostra (Cimento Portland Branco + Água) em aumento de $2000 \mathrm{x}$

FIGURA 23. Micrografia eletrônica de varredura da amostra da amostra (Cimento Portland Branco + Água) em aumento de $5000 \mathrm{x}$

FIGURA 24. (a) Curva de Espectroscopia de Dispersão de Energia de Raios-X e

(b) Micrografia eletrônica de varredura da amostra (Cimento Portland Branco + Água) em aumento de 2000x

FIGURA 25. (a) Curva de Espectroscopia de Dispersão de Energia de Raios-X e

(b) Micrografia eletrônica de varredura da amostra (Cimento Portland Branco + Água) em aumento de 2000x

FIGURA 26. (a) Curva de Espectroscopia de Dispersão de Energia de Raios-X e

(b) Micrografia eletrônica de varredura da amostra (Cimento Portland Branco + Água) em aumento de 2000x

FIGURA 27. (a) Curva de Espectroscopia de Dispersão de Energia de Raios-X e (b) Micrografia eletrônica de varredura da amostra (Cimento Portland Branco + Água) em aumento de 2000x

FIGURA 28. (a) Curva de Espectroscopia de Dispersão de Energia de Raios-X e (b) Micrografia eletrônica de varredura da amostra (Cimento Portland Branco + Água) em aumento de 7000x

FIGURA 29. Micrografia eletrônica de varredura da amostra (Cimento Portland Branco + Hidroxiapatita +Água) em aumento de 500x

FIGURA 30. Micrografia eletrônica de varredura da amostra (Cimento Portland Branco + Hidroxiapatita +Água) em aumento de 2000x

FIGURA 31. Micrografia eletrônica de varredura da amostra (Cimento Portland Branco + Hidroxiapatita +Água) em aumento de 5000x

FIGURA 32. Micrografia eletrônica de varredura da amostra (Cimento Portland Branco + Hidroxiapatita +Água) em aumento de 2000x

FIGURA 33. (a) Curva de Espectroscopia de Dispersão de Energia de Raios-X e (b) Micrografia eletrônica de varredura da amostra (Cimento Portland Branco + Hidroxiapatita + Água) em aumento de 2000x.

FIGURA 34. (a) Curva de Espectroscopia de Dispersão de Energia de Raios-X e (b) Micrografia eletrônica de varredura da amostra (Cimento Portland Branco + Hidroxiapatita + Água) em aumento de 2000x.

FIGURA 35. Curva de Calorimetria Exploratória Diferencial da amostra do Compósito (Cimento Portland Branco + Hidroxiapatita + Colágeno 
FIGURA 36. Curvas Termogravimétricas das matérias-primas e do Compósito (Cimento Portland Branco + Hidroxiapatita + Colágeno

FIGURA 37. Espectros de infravermelho obtidos para:- Hidroxiapatita, Cimento Portland Branco, - Colágeno 24horas, Compósito(Cimento Portland Branco + Hidroxiapatita +

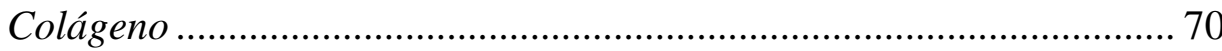

FIGURA 38. Micrografia eletrônica de varredura da amostra do Compósito (Cimento Portland Branco + Hidroxiapatita + Colágeno 24h) em aumento de $300 \mathrm{x}$.

FIGURA 39. Micrografia eletrônica de varredura da amostra do Compósito (Cimento Portland Branco + Hidroxiapatita + Colágeno 24h) em aumento de 500x

FIGURA 40. Micrografia eletrônica de varredura da amostra do Compósito (Cimento Portland Branco + Hidroxiapatita + Colágeno 24h) em aumento de $1000 \mathrm{x}$

FIGURA 41. Micrografia eletrônica de varredura da amostra do Compósito (Cimento Portland Branco + Hidroxiapatita + Colágeno 24h) em aumento de 2000x

FIGURA 42. Porcentagem dos elementos das amostras dos grupos 1,2 e 3.

FIGURA 43. (a) Curva de Espectroscopia de Dispersão de Energia de Raios-X e (b) Micrografia eletrônica de varredura da amostra do Compósito (Cimento Portland Branco + Hidroxiapatita + Colágeno 24h) em aumento de $2000 \mathrm{x}$

FIGURA 44. (a) Curva de Espectroscopia de Dispersão de Energia de Raios-X e (b) Micrografia eletrônica de varredura da amostra do Compósito (Cimento Portland Branco + Hidroxiapatita + Colágeno 24h) em aumento de $2000 \mathrm{x}$

FIGURA 45. (a) Raio-X periapical de um dente com Compósito( Cimento Portland + Hidroxiapatita + Colágeno 24h) na câmara pulpar ao lado do cilindro da amostra; (b) Dente com Compósito no interior da câmara pulpar; (c) Dente preparado para Pulpotomia. 


\section{LISTA DE TABELAS}

TABELA 1. - Principais Biomateriais utilizados em implantes ............................... 16

TABELA 2. - Formas das Hidroxiapatitas usadas em medicina e odontologia......... 43

TABELA 3. - Perda de massa das preparações obtidas das respectivas curvas

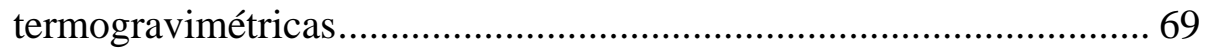

TABELA 4. - Resultados de Espectroscopia de Dispersão de Energia de Raios$\mathrm{X}$ para as amostras dos grupos 1, 2 e 3, conforme a preparação citadas nos itens III.1.4, III.3.A.1 e III.3.B.1, respectivamente ......... 74 


\title{
LISTA DE ABREVIATURAS E SIGLAS
}

\author{
ADA - American Dental Association \\ Asn - Asparagina \\ BMP - Proteína Osteomorfogenética \\ CPB - Cimento Portland Branco
}

Col 24 - Colágeno Tipo1 Serosa Porcina (24 h)

CPBHAC - Cimento Portland Branco + Hidroxiapatita Sintética (JARCHO) + Colágeno I

CPBHAW - Cimento Portland + Hidroxiapatita (JARCHO) + Água

CPBW - Cimento Portland Branco + Água

DSC - Calorimetria Exploratória Diferencial

EDX - Espectroscopia de dispersão de Energia de Raios-X

EDTA - Etilenodiaminotetracético

FDA - US Food and Drug Administration

FTIR - Espectroscopia na região do infravermelho

Gly - Glicina

Gln - Glutamina

HA - Hidroxiapatita Sintética (JARCHO)

Hyp - Hidroxiprolina

IRM - Material restaurador Intermediário

ISO - International Standards Organization

MTA - Agregado Trióxido Mineral

MEV - Microscopia Eletrônica de varredura

NBR - Norma Brasileira

OZE - Óxido de Zinco e Eugenol

OP - Proteína Osteogênica

Pro - Prolina

TG - Análise Térmogravimétrica

$\beta$ - TCP - Beta fosfato tricálcio 


\section{SUMÁRIO}

\section{LISTA DE FIGURAS}

LISTA DE TABELAS

LISTA DE ABREVIATURAS E SIGLAS

RESUMO

ABSTRACT

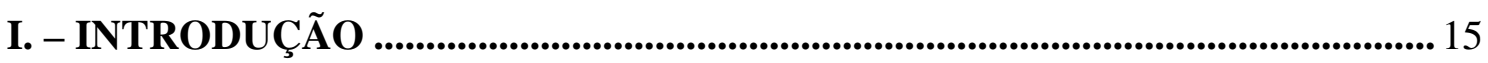

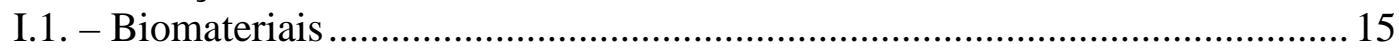

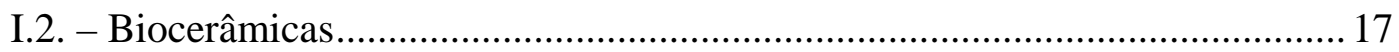

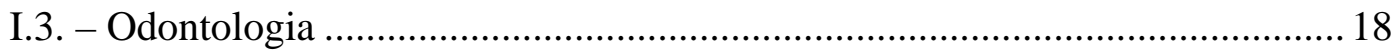

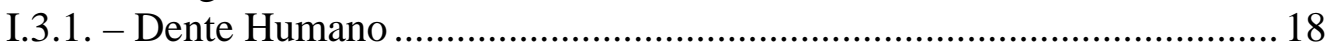

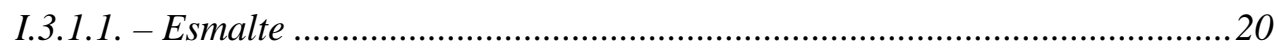

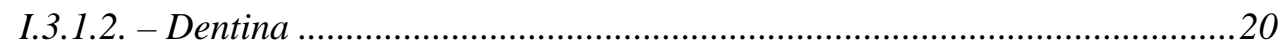

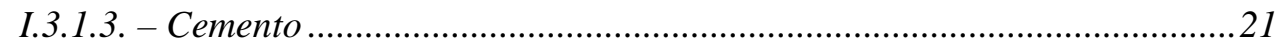

I.3.1.4. - Ligamento Periodontal ou Desmodonto ................................................22

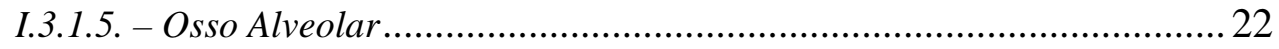

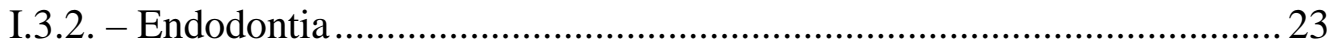

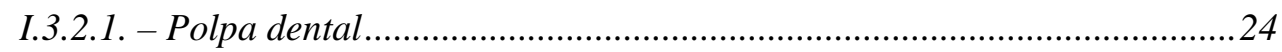

I.3.2.2. - Canais Acessórios...................................................................................25

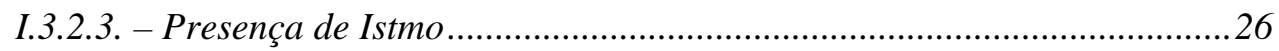

I.3.2.4. - Presença de Foraminas ......................................................................2

I.4. - Materiais utilizados em Capeamento Pulpar Direto e Pulpotomia ................ 28

I.4.1. - Hidróxido de Cálcio ................................................................................ 33

I.4.2. - Óxido de Zinco e Eugenol (OZE)...................................................... 33

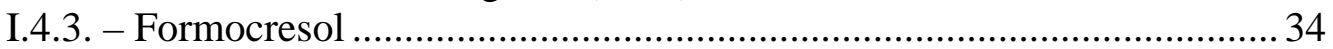

I.4.4. - Proteína Osteogênica ou Osteomorfogenética..................................... 34

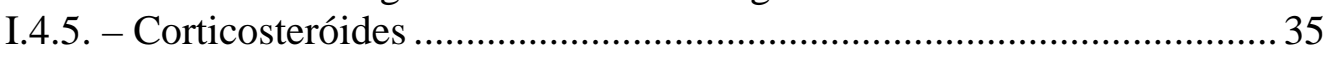

I.4.6. - Agregado de Trióxido Mineral (MTA).............................................. 36

I.5. - As Bases para Desenvolvimento do Compósito de colágeno com silicato e

hidroxiapatita como material para Endodontia ............................................ 37

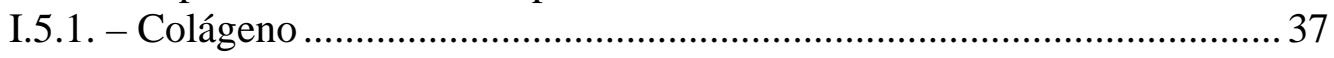

I.5.2. - Cimento Portland Branco ................................................................. 41

I.5.3. - Hidroxiapatita ...................................................................................... 42

I.6. - Estudo da influência do Mercúrio $(\mathrm{Hg})$ e do Chumbo $(\mathrm{Pb})$ frente à obtenção de um biomaterial......................................................................................... 44

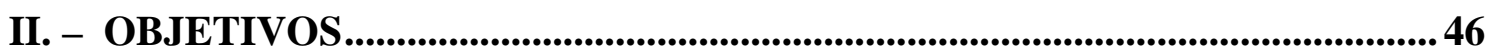

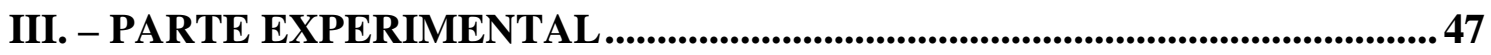

III.1. - Preparação dos materiais................................................................. 47

III.1.1. - Colágeno Aniônico.......................................................................... 47

III.1.2. - Cimento Portland Branco (CPB) - (NBR 12989) .............................. 48

III.1.3. - Hidroxiapatita ( HA) ....................................................................... 48

III.1.3.1. - Síntese e resumo da técnica................................................. 48

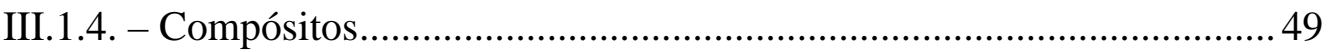

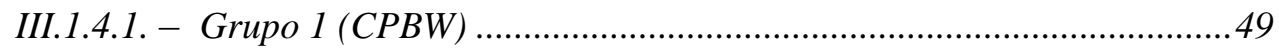

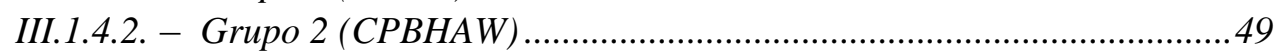

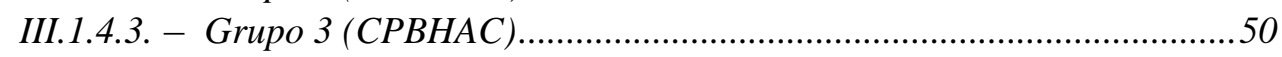

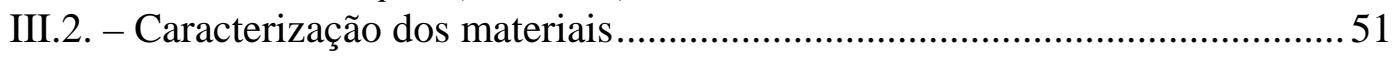




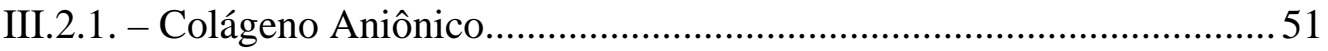

III.2.1.1. - Preparação das membranas................................................................51

III.2.1.2. - Calorimetria Exploratória Diferencial (DSC)....................................51

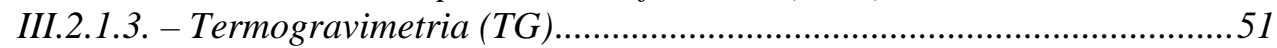

III.2.1.4. - Espectroscopia na região do Infravermelho (FTIR) ................. 51

III.2.2. - Cimento Portland Branco (CPB)................................................... 52

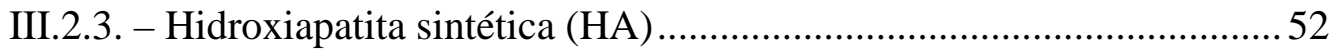

III.2.4. - Compósitos Grupos 2 e 3 ….......................................................... 52

III.2.4.1. - Microscopia Eletrônica de Varredura (MEV)........................... 52

III.2.4.2. - Espectroscopia de Dispersão de Energia de Raios-X (EDX) .. 53

III.2.4.3. - Medidas de $\mathrm{pH}$........................................................................... 53

III.2.4.4. - Verificação da Radiopacidade do Compósito em Relação ao Dente Humano com Raios-X ..................................................... 53

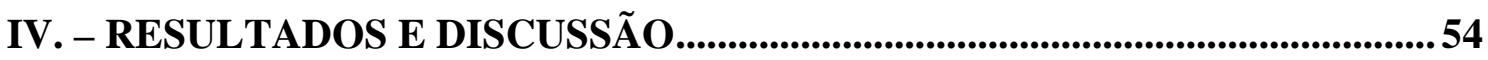

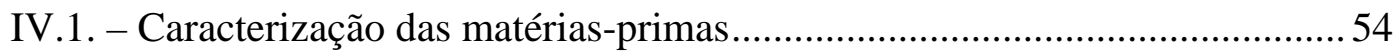

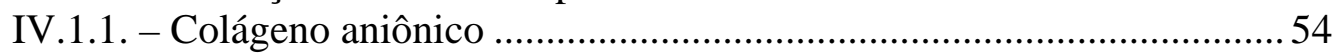

IV.1.2. - Cimento Portland Branco (CPB) .....................................................5 5

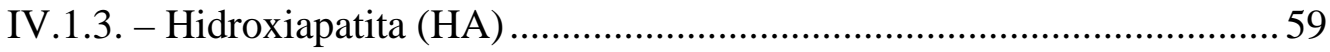

IV.2. - Caracterização das amostras complementares ........................................... 60

IV.2.1. - Microscopia Eletrônica de Varredura (MEV) do grupo 1 (Cimento Portland Branco + Água) (CPBW) .................................................. 60

IV.2.1.1. - Espectroscopia de Dispersão de Energia de Raios -X (EDX) do grupo 1 ( Cimento Portland Branco + Água (CPBW) .........61

IV.2.2. - Microscopia Eletrônica de Varredura (MEV) do grupo 2 (Cimento Portland Branco + Hidroxiapatita + Água) (CPBHAW) .................. 64

IV.2.2.1. - Espectroscopia de Dispersão de Energia de Raios -X (EDX) do grupo 2 ( Cimento Portland Branco + Hidroxiapatita + Água (CPBHAW) .......................................................................66

IV.3. - Caracterização do Compósito de colágeno com silicato e hidroxiapatita com material para endodontia....

IV.3.1. - Grupo 3 (Cimento Portland Branco + Hidroxiapatita + Colágeno (CPBHAC)

IV.3.2. - Microscopia Eletrônica de Varredura (MEV) do grupo 3 (Cimento Portland Branco + Hidroxiapatita + Colágeno (CPBHAC) .............. 70

IV.3.3. - Espectroscopia de Dispersão de Energia de Raios -X (EDX) do grupo 3 (Cimento Portland Branco + Hidroxiapatita + Colágeno (CPBHAC)

IV.3.4. - Verificação da Radiopacidade do Compósito (CPBHAC) em relação ao Dente Humano com RX ............................................................ 75

IV.4. - Considerações gerais do Compósito (CPBHAC) .......................................76 


\section{INTRODUÇÃO}

\section{I.1. - Biomateriais}

Um biomaterial é definido como uma substância ou combinação de duas ou mais substâncias, de natureza sintética ou natural, que pode ser utilizada por um período de tempo, para melhorar, aumentar ou substituir, parcial ou inteiramente tecidos ou órgãos. São exemplos, aqueles materiais que substituem ou induzem o crescimento de tecido ósseo, cartilagens, ligamentos, peles e reparação de tecido como a polpa dentária (WILLIAM, 1987; SILVER \& DOILLON, 1989).

De acordo com a sua natureza química, um biomaterial pode ser classificado em duas grandes categorias: os naturais, que incluem o colágeno, a seda, a queratina, a elastina, polissacarídeos e tecidos como o pericárdio bovino, serosas (bovina e porcina) e os sintéticos, que incluem as cerâmicas, os polímeros sintéticos, metais e ligas metálicas e os materiais compósitos (PARK, 1984). A Tabela 1 apresenta alguns exemplos de biomateriais de origem sintética utilizados em implantes.

Vários estudos levaram ao desenvolvimento de novos materiais, que não visavam apenas o preenchimento de espaço, mas também estimulavam uma resposta biológica quando implantados (LANGER et al., 1993; PARK 1984; MOONEY et al., 1996; MOONEY et al., 1997), dando início a era moderna de biomateriais. 
TABELA 1. - Principais biomateriais utilizados em implantes (EVANS et al., 1999).

\begin{tabular}{|c|c|c|c|c|}
\hline Materiais & Vantagens & Desvantagens & Exemplos & Aplicações \\
\hline Metais e Ligas & $\begin{array}{l}\text { Altas resistências } \\
\text { mecânicas à tração, ao } \\
\text { impacto, à fadiga e ao } \\
\text { desgastes. }\end{array}$ & $\begin{array}{l}\text { Baixa } \\
\text { biocompatibi- } \\
\text { lidade, corrosão } \\
\text { em meio } \\
\text { fisiológico, alta } \\
\text { densidade, } \\
\text { diferença de } \\
\text { propriedades } \\
\text { mecânicas com } \\
\text { relação a tecidos } \\
\text { moles. }\end{array}$ & $\begin{array}{l}\text { Pt, Pt-Ir, Au, aços } \\
\text { 316, 316L, ligas Co- } \\
\text { Cr, Ti, e ligas } \\
\text { Ti6Al4V e } \\
\text { Ti6Al17Nb }\end{array}$ & $\begin{array}{l}\text { Eletrodos, fios, } \\
\text { placas, } \\
\text { parafusos, } \\
\text { cravos, } \\
\text { grampos, pinos, } \\
\text { próteses } \\
\text { articulares e } \\
\text { implantes } \\
\text { dentários. }\end{array}$ \\
\hline Polímeros & $\begin{array}{l}\text { Resistência, facilidade } \\
\text { de fabricação, baixa } \\
\text { densidade, boa } \\
\text { biocompatibilidade }\end{array}$ & $\begin{array}{l}\text { Baixa resistência } \\
\text { mecânica, } \\
\text { degradação } \\
\text { dependente do } \\
\text { tempo. }\end{array}$ & $\begin{array}{l}\text { Polietileno, } \\
\text { poliuretano, } \\
\text { polimetacrilato de } \\
\text { metila, } \\
\text { politetrafluoretile- } \\
\text { no, nylon, dracon, } \\
\text { silicone e ácido } \\
\text { polilático. }\end{array}$ & $\begin{array}{l}\text { Superfícies } \\
\text { articulares, } \\
\text { vasos, } \\
\text { cartilagens, } \\
\text { cimento } \\
\text { ortopédicos, } \\
\text { sutura, } \\
\text { substituições de } \\
\text { tecidos moles, } \\
\text { placas de } \\
\text { reparação óssea }\end{array}$ \\
\hline Cerâmicas & $\begin{array}{l}\text { Boa compatibilidade, } \\
\text { resistência à corrosão, } \\
\text { inércia química, alta } \\
\text { resistência a } \\
\text { compressão }\end{array}$ & $\begin{array}{l}\text { Baixa resistência } \\
\text { ao impacto, } \\
\text { dificuldade de } \\
\text { fabricação, baixa } \\
\text { reprodutibi-lidade } \\
\text { nas propriedades } \\
\text { mecânicas, alta } \\
\text { densidade }\end{array}$ & $\begin{array}{l}\text { Alumina, zircônia, } \\
\text { fosfato tricálcio, } \\
\text { hidroxiapatita, } \\
\text { biovidro, carbono } \\
\text { (vítreo), e carbono } \\
\text { pirolítico. }\end{array}$ & $\begin{array}{l}\text { Cabeças de } \\
\text { fêmur, } \\
\text { odontologia, } \\
\text { reconstrução } \\
\text { óssea, } \\
\text { ligamentos } \\
\text { artificiais, } \\
\text { revestimentos } \\
\text { reabitáveis, } \\
\text { revestimentos } \\
\text { hemocompa- } \\
\text { tíveis }\end{array}$ \\
\hline Compósitos & $\begin{array}{l}\text { Boa biocompatibili- } \\
\text { dade, inércia química, } \\
\text { resistência a corrosão, } \\
\text { alta resistência a } \\
\text { tração }\end{array}$ & $\begin{array}{l}\text { Dificuldade de } \\
\text { fabricação }\end{array}$ & $\begin{array}{l}\text { teflon-carbono, } \\
\text { carbono-carbono, } \\
\text { nylon-poliuretano. }\end{array}$ & $\begin{array}{l}\text { Cartilagens, } \\
\text { odontologia, } \\
\text { ortopedia, } \\
\text { substituições de } \\
\text { tecidos moles. }\end{array}$ \\
\hline
\end{tabular}


Do ponto de vista geral um biomaterial deve apresentar as seguintes características (PARK, 1984):

1 - Ser biocompatível, isto é, não induzir a respostas teciduais ou imunológicas adversas;

2 - Não ser tóxico ou carcinogênico;

3 - Ser quimicamente projetado para suas funções de uso;

4 - Estabilidade mecânica adequada ao seu uso;

5 - Peso e densidade adequados;

6 - Ter custo relativamente baixo, ser reprodutível e de fácil fabricação.

7 - Estimular reações biológicas favoráveis em relação a sua função de uso.

Entre estas características, a biocompatibilidade é ponto de destaque, pois, é a primeira qualidade importante do ponto de vista biológico de um biomaterial. A biofuncionalidade é observada quando a biocompatibilidade é adequada. Quando um material estranho ao hospedeiro entra em contato com o tecido ou com os fluidos biológicos, respostas de proteção são desencadeadas e se manifestam em primeira instância como processos inflamatórios ou imunológicos visando a eliminação do corpo estranho.

Excetuando-se os processos imunológicos, reações de "eliminação", incluem processos de reabsorção, encapsulamento ou processos de calcificação (SILVER, 1989), resultantes do processos inflamatório inicial. O bom desempenho de um biomaterial pós implante está associado ao equilíbrio entre a biocompatibilidade e a biofuncionalidade (PARK, 1984; SILVER, 1989).

\section{I.2. - Biocerâmicas}

Os primeiros dados sobre a utilização de materiais cerâmicos como enxerto ósseo, começam com ALBEE (1920) que utilizou uma cerâmica de fosfato tricálcico para regenerar um defeito ósseo e para a formação de osso novo. Entretanto, somente 50 anos depois começaram a aparecer diferentes tipos de cerâmicas de fosfato de cálcio como materiais implantáveis para aplicação em medicina e odontologia. Em 1974 foi publicada a primeira aplicação odontológica do $\beta$-fosfato tricálcico no tratamento de doenças periodontais (LEVITT et al., 1969; MONROE et al., 1971), seguindo-se em 1975, pelo trabalho de NERY et al., (1975), com $\beta$-fosfato tricálcico, com a introdução 
do conceito de porosidade como uma característica importante para estes tipos de biocerâmicas.

A grande aceitação das biocerâmicas a base de sais de fosfato de cálcio devese, principalmente, ao seu alto grau de biocompatibilidade, que provavelmente está associado a sua similaridade química com os materiais normalmente encontrados no tecido ósseo (DAVIES, 1990). Entre as cerâmicas com melhor desempenho (HENCH, 1991), estão os biovidros, a alumina, o $\beta$-TCP (Beta-Fosfato tricálcico) e a hidroxiapatita.

\section{I.3. - Odontologia}

Dentro do conceito atual da moderna ciência odontológica, as formações que circundam os dentes, isto é, a gengiva, o periodonto, o cemento e o osso alveolar, desempenham relevante papel na mastigação, na estética facial e na higidez desses elementos encarregados de agirem, inicialmente, no preparo dos alimentos ingeridos e posterior aproveitamento pelo tubo digestivo(FIGUN \& GARINO, 1980).

O aparelho mastigador é formado pelos órgãos dentários (dentes), maxila, mandíbula, articulação temporo-mandibular, músculos mastigadores, músculos cutâneos, língua, glândulas salivares, vasos e nervos (NEVES, 2001).

O órgão dentário é constituído pelo dente e periodonto (gengiva, desmodonto, cemento e osso alveolar), DUARTE (2003).

\section{I.3.1. - Dente Humano}

Os dentes são órgãos mineralizados, resistentes, esbranquiçados e implantados em ossos próprios, os ossos alveolares, anexados à maxila e a mandíbula. Os dentes estão dispostos em duas fileiras harmônicas, superior e inferior, formando as arcadas dentárias. Estas arcadas e os respectivos ossos suportes separam a ampla cavidade bucal em partes funcionalmente diversas: o vestíbulo e a cavidade bucal propriamente dita.

Do ponto de vista anatômico e descritivo, o dente é formado de três partes distintas: coroa, colo e raiz. A coroa dentária é a porção visível e funcionante na mastigação e seu aspecto particular distingue-a de imediato das demais partes. Ela é 
brilhante e permanece acima dos ossos suportes e da gengiva, desempenhando suas funções de acordo com sua anatomia (PICOSSE, 1980).

O colo é o segmento intermediário entre a coroa e a raiz. É a parte mais estrangulada do dente e é limitada por uma linha sinuosa entre a coroa e a raiz dentária.

A fixação do dente no seu osso alveolar dá-se por intermédio da raiz. A raiz dentária é o segmento amarelado do dente que está alojado em cavidade própria, no interior do osso. A raiz do dente sempre tem um comprimento maior do que a coroa e sofre, também maior número de variações morfológicas.

Do ponto de vista arquitetural, e estrutural, o dente pode ser descrito como sendo formado de quatro partes: esmalte, dentina, cemento e polpa (DUARTE, 2003). As três primeiras formações são duras, calcificadas, enquanto que a polpa é o único tecido mole do dente (Figura 1).

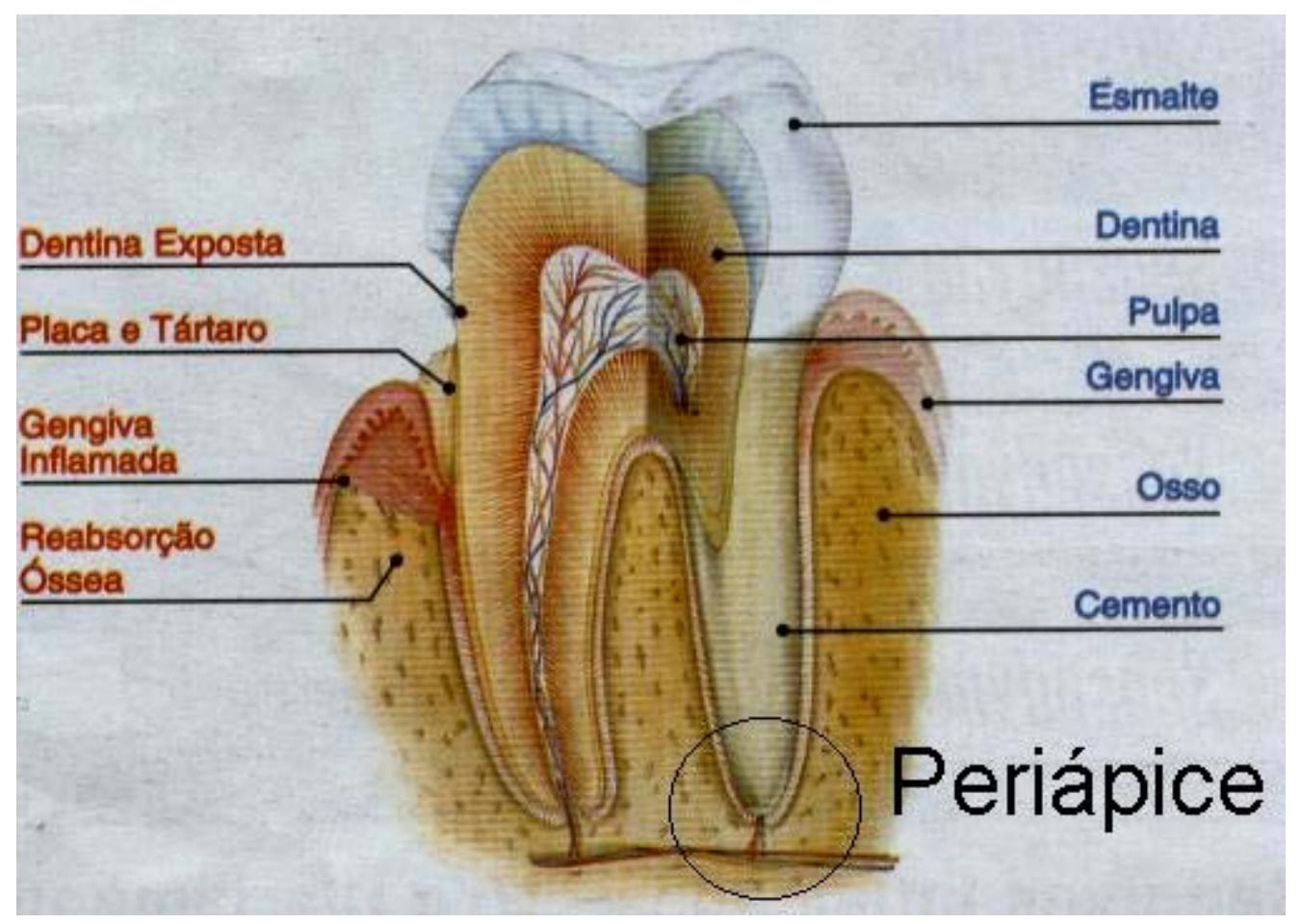

FIGURA 1. - Desenho esquemático de um Dente Humano com suas estruturas internas e adjacentes.

No terço apical da raiz encontra-se o periápice que é constituído de três estruturas distintas: o cemento, o ligamento periodontal e o osso alveolar. Esta tríade tem a finalidade principal de manter os dentes fixados aos maxilares. 


\section{I.3.1.1. - Esmalte}

O esmalte ou camada Adamantina é o revestimento exterior da coroa dentária. Este tecido, bastante mineralizado e resistente, é de origem ectodérmica e tem o aspecto geral de um capuz sobre o molde de dentina coronária. O esmalte termina no colo do dente, ao nível da junção cemento-esmalte ou amelo-dentinária.

Estruturalmente, o esmalte é formado por unidades calcificadas, os prismas de esmalte, que em cortes longitudinais vêm-se começando na junção amelo-dentinária, dirigindo-se paralela e ininterruptamente até a superfície exterior do dente.

A microscopia eletrônica tem conseguido demonstrar que existe uma matriz orgânica fibrilar na espessura dos prismas, onde se depositam cristais de apatita, quer nas malhas destas fibrilas, quer ao redor delas (PICOSSE, 1980).

\section{I.3.1.2 - Dentina}

Trata-se de uma estrutura dentária com vitalidade propiciada pelos odontoblastos. Constitui a maior parte do dente, estando coberta na parte externa da coroa pelo esmalte e, na raiz, pelo cemento. O tecido dentinário pode ser entendido como uma extensão do tecido pulpar, porém com forma física diferente (WATTS \& PATERSON, 1983).

O termo “complexo dentina-polpa” diz da íntima relação existente entre os dois tecidos. A dentina apresenta túbulos dentinários normalmente ocupados pelos prolongamentos odontoblásticos. Devido à sua estrutura altamente permeável, não deve ficar em contato com os fluidos bucais, daí o fato de se apresentar protegida (PASHLEY, 1985; PASHLEY, 1988; PASHLEY, 1992).

A dentina compõe-se de setenta por cento de parte inorgânica e trinta por cento de orgânica. Os cristais de hidroxiapatita constituem a primeira parte e a segunda é principalmente representada por colágeno (vinte por cento) e água (dez por cento).

Entende-se por pré-dentina a parte não-mineralizada da matriz dentinária, localizada entre a camada odontoblástica e a dentina já calcificada. Possui colágeno tipo I, ácido condroitínico e glicosaminoglicanos (DODD \& CARMICHAEL, 1979).

A dentina apresenta distinto arranjo de fibras e disposição dos cristais de hidroxiapatita em toda a sua estrutura, o que resulta em diferentes coeficientes de tensão 
e elasticidade. Assim, apresenta vários graus de resistência. A dentina é permeável (PASHLEY, 1985). A presença de prolongamentos odontoblásticos em sua intimidade permite o fluxo de líquidos. Apresenta grande quantidade de fluido, semelhante ao plasma, que devido à composição desse líquido, representa um bom meio nutriente para bactérias, principalmente quando a polpa é exposta ao meio bucal e não é tratada.

Os microrganismos que se encontram na dentina não têm mobilidade e seu avanço nos túbulos é obtido por meio de sucessivas divisões celulares (MICHELICH et al., 1980 - Figura 2).

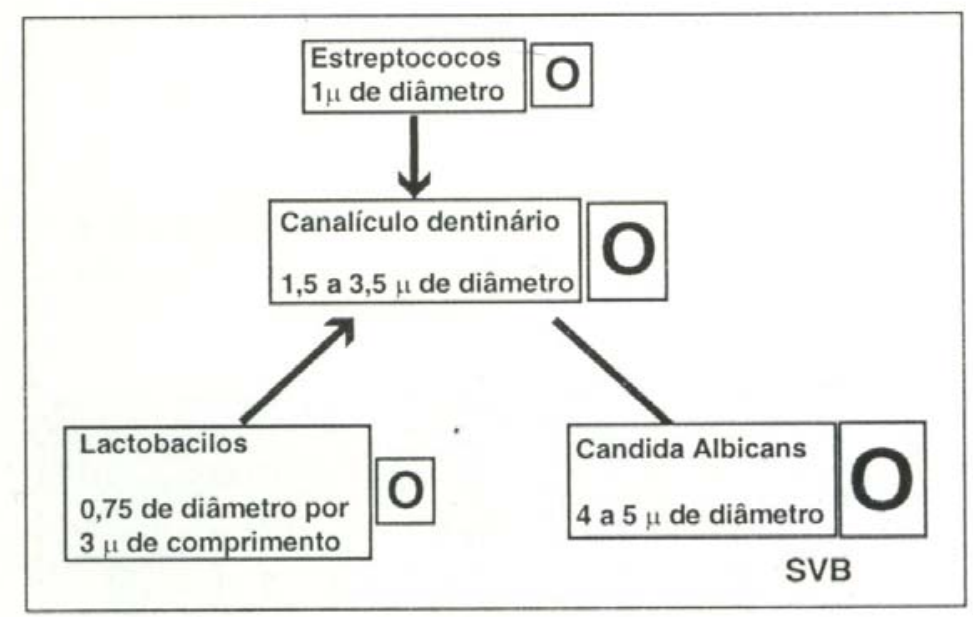

FIGURA 2. - Relação entre tamanho de microrganismos e túbulos dentinários (BARBOSA, 1999).

Por conta dessa permeabilidade, pode haver difusão de material tóxico do canal aos tecidos periodontais através da dentina (EHNEVID et al.,1995). Adicionalmente, agentes externos podem também causar inibição do metabolismo pulpar (COHEN, 1979; HAMERSKY, 1980; HATA, 1989).

\section{I.3.1.3. - Cemento}

O cemento é um tecido dental mineralizado que envolve toda a dentina, desde a sua união com o esmalte até o ápice radicular. O seu grau de mineralização e a sua composição são semelhantes ao tecido ósseo compacto. Difere do osso, no entanto, pelo seu caráter avascular. O cemento tem uma série de funções, das quais a mais eminente é proporcionar as condições necessárias para retenção das fibras colágenas - mecanismo de união entre o dente e o osso alveolar (BOZZO \& HIZATUGU, 1973; JUNQUEIRA \& CARNEIRO, 1999). Paralelamente, exerce a função de tecido reparador, depositando 
cemento novo para proteger a dentina, quando os tecidos radiculares sofrem agressões ou injúrias de qualquer natureza. Atribui-se a ele a responsabilidade de adaptação funcional dos dentes (ORBAN, 1978).

\section{I.3.1.4. - Ligamento Periodontal ou Desmodonto}

É originário do tecido conjuntivo, possuindo fibras colágenas dispostas de tal forma que suportam pressões da mastigação. Localiza-se entre o cemento e o osso alveolar. Portanto o ligamento periodontal une o cemento ao osso alveolar (DUARTE, 2003).

Tem como principais funções as de suporte, sensorial, nutritiva e homeostática. A função sensorial, através do sistema nervoso, protege o órgão dental dos efeitos que poderiam ser provocados pelos excessos do movimento mastigatório.

A função nutritiva, via corrente sangüínea, tem por finalidade alimentar os elementos celulares que compõem o ligamento periodontal. Por fim, temos a função homeostática, encarregada de reabsorver e sintetizar a substância extracelular contida no tecido conjuntivo que compõe o ligamento, o cemento e o osso alveolar.

\section{I.3.1.5. - Osso Alveolar}

O tecido ósseo é um tipo de tecido conjuntivo formado por células e um material intercelular calcificado, a matriz óssea, constituída de uma parte orgânica, o colágeno e uma parte mineral correspondente, na sua maioria pela hidroxiapatita (PARK, 1984; SILVER \& DOILLON, 1989; HAM, 1963; DAVIES, 1990; JUNQUEIRA \& CARNEIRO, 1999). Em menor porcentagem são encontrados também, citrato $\left(\mathrm{C}_{6} \mathrm{H}_{5} \mathrm{O}_{7}^{4-}\right)$, carbonato $\left(\mathrm{CO}_{3}^{2-}\right)$, fluoreto $\left(\mathrm{F}^{-}\right)$e hidróxidos $\left(\mathrm{OH}^{-}\right)$de cálcio, responsáveis pelas diferenças funcionais do tecido ósseo (PARK, 1984; MANN et al., 1989). A relação cálcio/fósforo no tecido ósseo pode variar entre 1,5 a 1,77 (SILVER \& DOILLON, 1989; MANN et al., 1989) e, essencialmente, distribuída dentro da matriz molecular da fase orgânica que é o colágeno.

O osso alveolar apresenta-se como uma fina lâmina, contornando a raiz do dente (Figura 3). A ela compete fixar as fibras principais oriundas do ligamento 
periodontal. Pelo seu interior passam vasos e nervos destinados ao ligamento periodontal e estruturas adjacentes (BAUMANN, 1984).

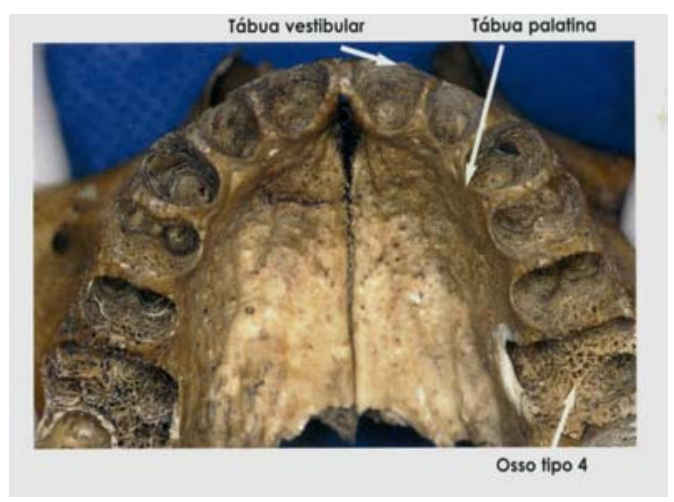

FIGURA 3. - Alvéolos dentais da maxila

\section{I.3.2. - Endodontia}

A Endodontia é o ramo da Odontologia relacionado ao estudo, diagnóstico, à prevenção e ao tratamento das doenças pulpares e suas manifestações nos tecidos periapicais. Dependendo das condições da polpa, periodonto e periápice têm-se uma terapêutica a ser executada. Quando o elemento dentário já possuir algum tratamento, as condições deste devem definir o tipo da futura abordagem. Os tratamentos podem ser classificados em conservadores, radicais ou cirúrgicos.

Entende-se como conservadores os capeamentos diretos ou indiretos, pulpotomia, apexogênese e apecificação. Como radicais os procedimentos de pulpectomia em dentes com polpa viva ou com polpa necrosada, seguidos de limpeza, conformação e obturação do sistema de canais radiculares (tratamento endodôntico ou de canal). Quando as possibilidades de tratamento se esgotam neste nível, temos os recursos cirúrgicos. A cirurgia parendodôntica representa a última opção terapêutica antes da avulsão dentária, sendo por isso ainda considerado um procedimento conservador para o dente (BARBOSA, 1999). 


\section{I.3.2.1. - Polpa dental}

É um tecido conjuntivo frouxo, bastante vascularizado, rico em fluidos, e possui células próprias, os odontoblastos que produzem a dentina (RUCH, 1985; TEN CATE, 1985). Apresenta também fibroblastos e células mesenquimais indiferenciadas, bem como macrófagos e células de defesa, imunocompetentes (HAHN et al., 1989). Sua parte estrutural compõe-se de fibras e substância fundamental (Figura 4). Localiza-se na parte central do dente, circundada pela dentina, o que não a impede de apresentar os fenômenos inflamatórios e reparacionais inerentes a qualquer tecido conjuntivo (KONTTINEN et al., 1989).

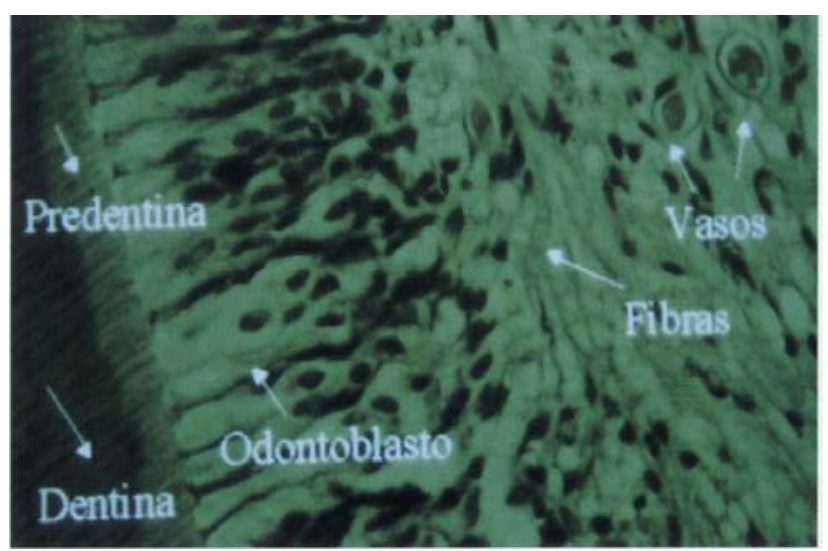

FIGURA 4. - Detalhes da Polpa dental Humana (BARBOSA, 1999).

Constitui-se de uma parte celular e outra intercelular. Na intercelular, situam-se substância fundamental, fibras, vasos e nervos (AVERY, 1971). Embora a polpa tenha comportamento similar ao dos órgãos de mesma linhagem, apresenta características especiais de estar confinada a paredes inextensíveis, ter células odontoblásticas e possuir circulação tipo terminal (VALDRIGHI \& HIZATUGU, 1973; KIM, 1985; KIM, 1990). Tais condições a fazem responder de maneira clinicamente diferente de outros tecidos e órgãos.

A polpa pode apresentar vitalidade e ao mesmo tempo ser portadora de alterações regressivas, inflamação dos mais variados graus e, ainda, áreas de necrose (MENDONZA, 1987). O fato de não apresentar dor não implica na ausência de fenômenos inflamatórios. 


\section{I.3.2.2. - Canais Acessórios}

A comunicação entre a polpa e o ligamento periodontal não está limitada á região apical. Os canais acessórios são encontrados em qualquer nível. Estudos sobre o sistema vascular indicam claramente o quanto numerosos e persistentes são estes canais. Muitos deles, com o tempo ficam obliterados com cemento e/ou dentina, mas muitos persistem. A maioria parece ser encontrada na metade apical da raiz, sendo que se observou que alguns passam diretamente da câmara pulpar para o ligamento periodontal. Assim, esses canais podem ser a causa de lesões endodônticas-periodontais (LOWMANN et al., 1973).

Cerca de 28,4 por cento dos canais acessórios encontram-se na região de furca e fazem comunicação da polpa com a superfície externa, via túbulos dentinários, especialmente onde o cemento foi removido (GUTMANN, 1978).

Alguns padrões de distribuição do canal radicular em dente humano podem ser subdivididos em Recorrentes, Reticulares, Interconexões laterais, Oblíquos e o Delta apical (Figura 5). Frente a estas variantes deve-se optar pelo tratamento conservador, ou seja, preservar a polpa dental até as ultimas conseqüências.

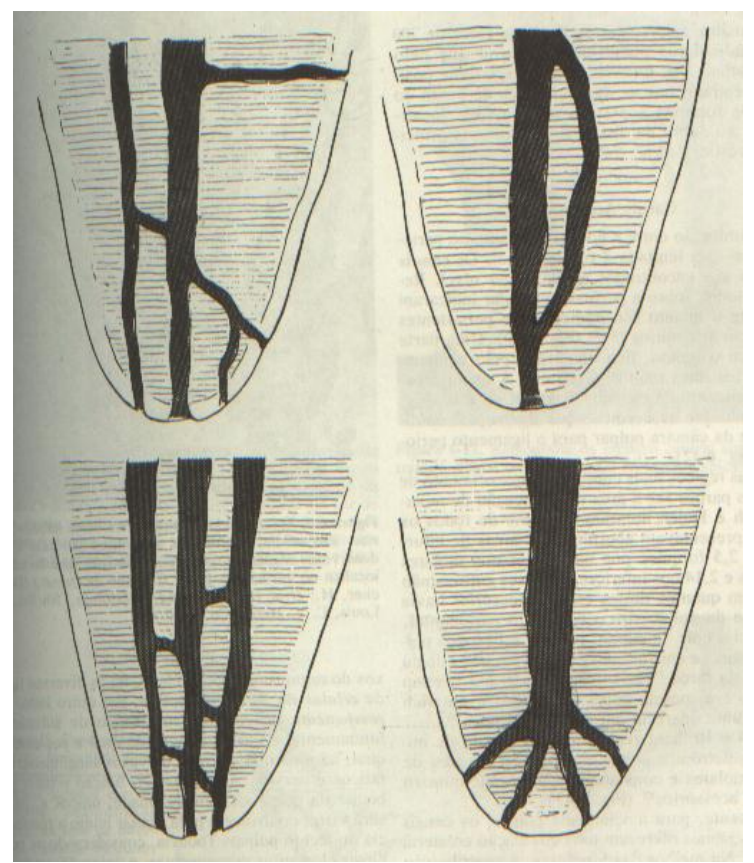

FIGURA 5. - Variedade de Condutos Radiculares. 
Os canais acessórios jamais oferecem uma circulação colateral adequada. Daí a contribuição destes canais ser mínima para o suprimento sangüineo total da polpa. Enclausurados pela dentina, poucos podem acrescentar quando o tecido pulpar está desprovido de seu suprimento sangüíneo apical. Por outro lado contribuem para a disseminação da contaminação do interior do dente para a região do ligamento (BRAMANTE et al., 2003).

\section{I.3.2.3. - Presença de Istmo}

O conhecimento da morfologia radicular é de fundamental importância para a realização, com sucesso, de procedimentos como tratamento endodôntico e de cirurgia parendodôntica como as apicectomias. Raízes achatadas apresentam, invariavelmente, ou um canal achatado ou a presença de dois canais independentes ligados por um istmo. O istmo é a estreita comunicação que existe entre dois ápices radiculares e contém tecido pulpar (Figura 6). Cerca de $75 \%$ das raízes mesiais de primeiros molares inferiores e $20 \%$ das raízes distais contêm istmos entre 3 e 4 mm do ápice (HSU \& KIM, 1997).
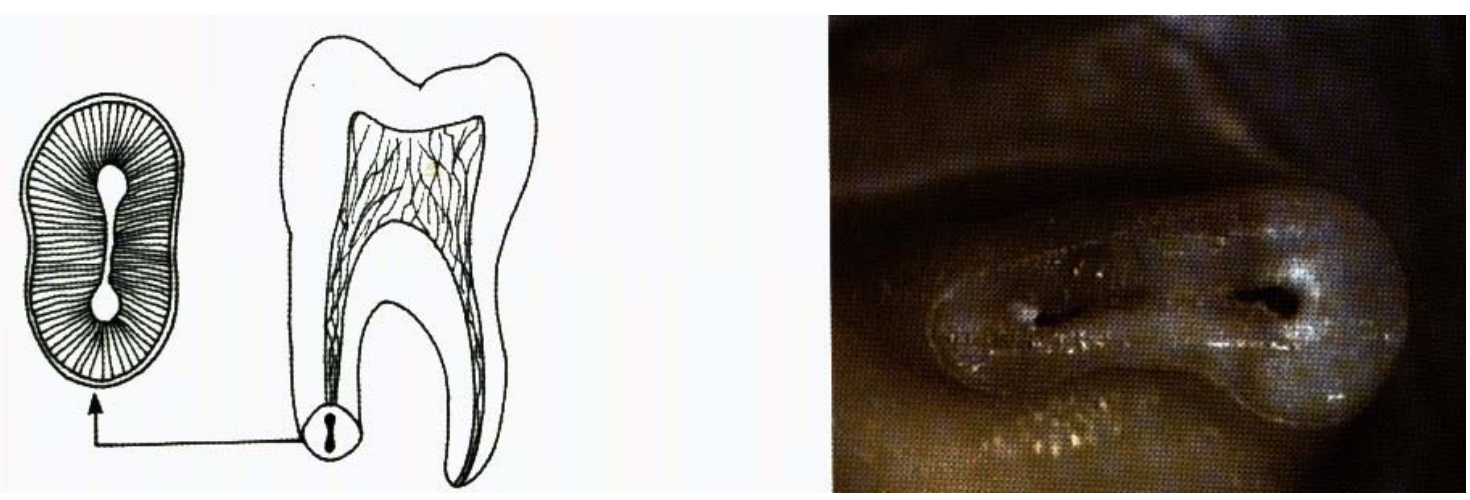

FIGURA 6. - Corte transversal de raiz evidenciando o Istmo (BARBOSA, 1999).

Esta é uma das razões porque grande número de apicectomias de raízes mesiais de molares inferiores fracassa. A preocupação com a existência do istmo é recente. No passado, não havia menção de identificação e manejamento do mesmo, devido à dificuldade de visualização a olho nu ou com o auxílio de lupas. Atualmente, com o uso de pontas de ultra-som e do microscópio clínico, o preparo apical que envolve o istmo pode ser feito sem dificuldade (BARBOSA, 1999). 


\section{I.3.2.4. - Presença de foraminas}

São pequenos orifícios ou forames que podem ser encontrados no assoalho da câmara pulpar de molares, comunicando a parte interna do dente (endodôntica), com a região de furca de raízes (molares inferiores) ou de trifurcação de raízes (molares superiores) conforme (Figuras 7 e 8).

As pesquisas sobre as porcentagens de canais laterais encontrados, ligando o assoalho da câmara pulpar ao periodonto, são discordantes e isso pode ser devido à anatomia própria de cada dente e, também, às metodologias empregadas (PÉCORA et al., 1990).

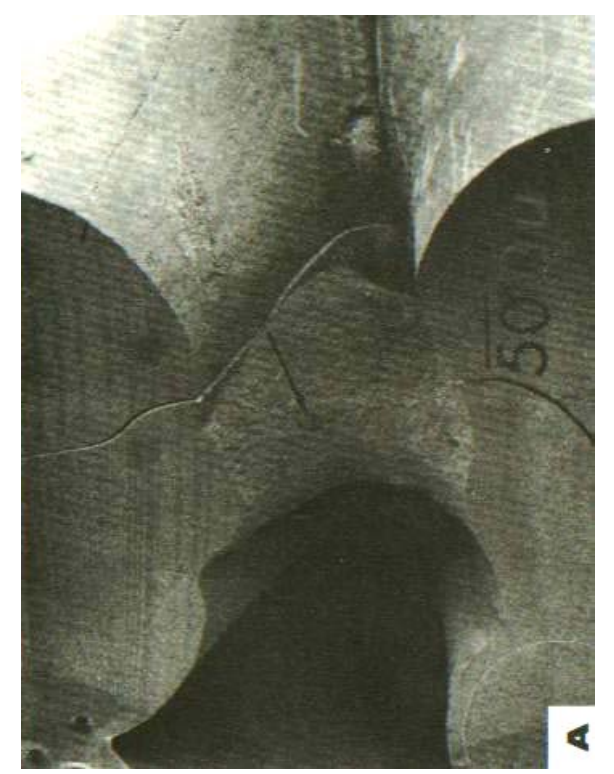

FIGURA 7. - Corte transversal de raízes de molar evidenciando a furca e o forame do canal acessório, indicado pela seta (aumento 20x).

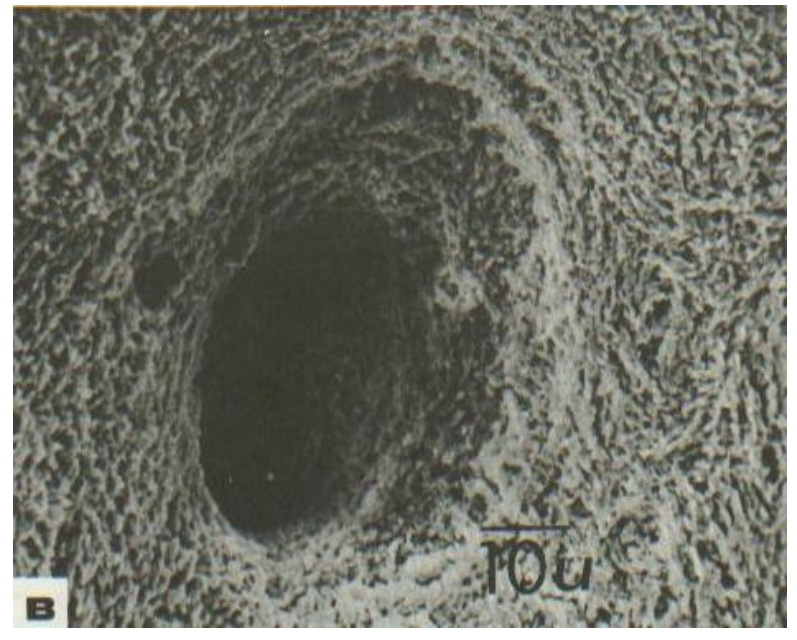

FIGURA 8. - O Forame visto em A, aumentado 1000x. O canal mede 35 micra, abrindo-se para 60 micra na superfície. 
LOWMAN et al., (1973) injetaram corante (hematoxilina) sob vácuo na câmara pulpar de molares humanos e notaram que o corante aparecia em 59\% das furcas examinadas, demonstrando a presença das foraminas.

Fizeram uma experiência injetando corante(hematoxilina) sem vácuo na câmara pulpar de 100 molares inferiores humanos e em 13 por cento dos casos o corante atingiu os canais da furca, confirmando a presença das foraminas (VERTUCCI et al., 1974).

BURCH \& HULEN, (1974) investigaram a área de furca e trifurcação de 190 molares humanos, sendo 95 superiores e 95 inferiores. E com auxílio de uma lupa constataram a presença de foraminas em 76 por cento dos dentes examinados, o que deu uma média de 2,14 foraminas para os molares inferiores, e de 2,5 para os molares superiores.

Ainda nesta linha de pesquisa, outro grupo de pesquisadores utilizaram o microscópio eletrônico de varredura e examinaram 40 molares inferiores humanos (20 jovens e 20 adultos). A incidência de foraminas acessórias na área da bifurcação foi muito maior do que a encontrada no assoalho da câmara pulpar (60 por cento e 15 por cento respectivamente). A análise estatística não revelou diferenças entre os grupos etários examinados. Os autores chamaram a atenção para o fato de que a deposição de cemento, na superfície externa da furca, cria um número de irregularidades que podem ser confundidas com foraminas (GOLDBERG et al., 1987).

ADRIAENS et al., (1988) mostraram, por meio de microscopia eletrônica de varredura, bactérias dentro dos túbulos dentinários em raízes de dentes com doença periodontal e sem lesões de cáries. A invasão bacteriana ocorreu em 87 por cento dos dentes periodontalmente afetados, sendo que 83 por cento destes apresentavam bactérias nas camadas dentinárias e 59 por cento, na polpa.

\section{I.4. - Materiais utilizados em capeamento pulpar direto e pulpotomia}

Capeamento pulpar direto é o procedimento onde se cobre a polpa dental exposta com curativo ou cimento, protegendo-a de injúrias adicionais e permitindo o reparo (Figura 9). As indicações para esse procedimento são: polpa exposta por acidente, exposição por cárie em dente assintomático. Havendo raiz incompletamente 
formada, este tratamento deve ser aplicado (BARBOSA, 1999; HOLLAND et al., 2001; TZIAFAS et al., 2002).

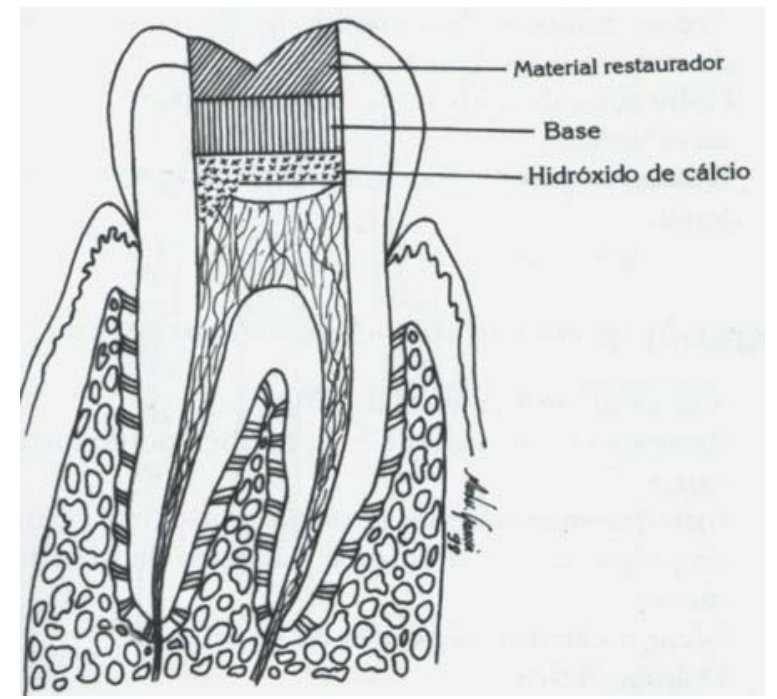

FIGURA 9. - Técnica de capeamento pulpar direto (BARBOSA, 1999)

O melhor conhecimento das condições fisiológicas da polpa permite aproveitar o potencial de reparo deste órgão e executar este procedimento alternativo ao tratamento endodôntico radical (PEREIRA et al., 1980; DEZAN et al.,1995)

Pulpotomia é o procedimento indicado para o tecido pulpar de dentes jovens exposto por cárie ou envolvidos por trauma. Trata-se da remoção cirúrgica da polpa coronária, sob condições assépticas e atraumáticas (Figura 10). Está indicada para polpas vitais, hígidas e preferencialmente livres de infecção. Em se tratando de criança ou adulto jovem, que possui boa resposta orgânica, a possibilidade de sucesso é maior. Pode ser indicada para dentes decíduos, onde o elemento dentário foi acometido por cárie profunda e é necessário mantê-lo na arcada dentária para evitar desordens oclusais (BIMSTEIN, 1985; WUCHERPFENNING \& GREEN, 1999; HOLLAND et al., 2001). 


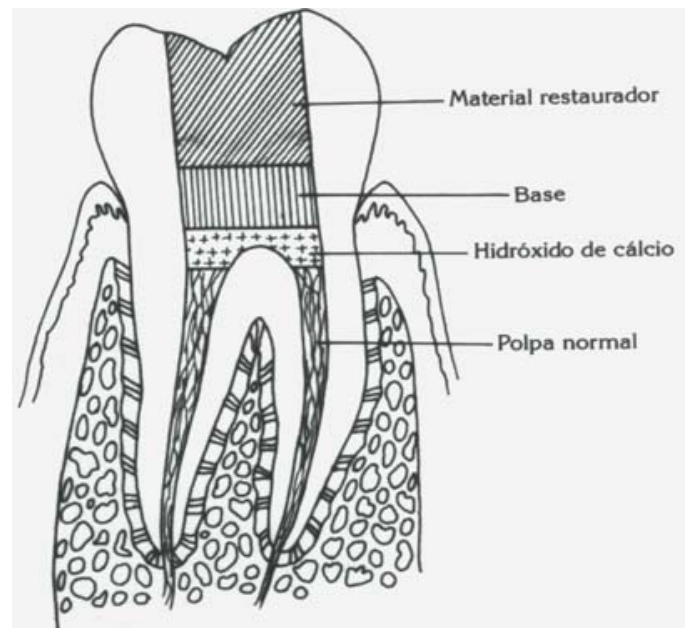

FIGURA 10. - Técnica de pulpotomia (BARBOSA, 1999).

Segundo HOLLAND \& RUSSO (1975); LIMA \& GARROCHO (1986) a pulpotomia tem sido considerada também em saúde pública, como meio de evitar a avulsão dental. Indiscutivelmente, entre remover o dente ou parte da polpa, deve-se dar prioridade ao procedimento de dano menor. Estudos com controle longitudinal da vitalidade pulpar nas raízes mostram bons resultados (MAGNUSSON, 1971; ROLLING \& THYLSTRUP, 1975; MAGNUSSON, 1980).

Apesar das críticas que a pulpotomia recebe, como calcificações indesejadas do canal, reabsorções internas e dificuldades de posterior tratamento endodôntico, vários trabalhos relatam um alto percentual de sucesso (ZANDER 1939; RAPPAPORT \& ABRAMSON, 1958; SOUZA \& HOLLAND, 1974; LOPES \& COSTA FILHO, 1987). Deve-se considerar também o grau de formação da raiz. Em raiz ainda não totalmente formada, a realização da pulpotomia propicia condições para a complementação do periápice.

Utiliza-se o termo apexogênese quando o procedimento de induzir a formação apical é feito em dente com polpa viva (BIO), mesmo que seja só a parte radicular. Deixando parte da polpa, a raiz continua sua formação normalmente (SAAD \& EGYPT, 1988; WEBBER, 1984; SCHUMACHER \& RUTLEDGER, 1993).

Apecificação implica na indução da formação radicular. Os dentes têm sua raiz complementada algum tempo após a erupção, em média 3 a 5 anos, podendo ser feita em qualquer idade (GHOSE et al., 1987; MORSE et al., 1990). Quando o procedimento é realizado em dente com polpa necrosada, a indução poderia ser feita com hidróxido de 
cálcio ou MTA e a formação radicular continuaria (SCHINDLER \& SCHWARTZ, 1989).

Quando se tratar de polpa viva, a manutenção da vitalidade pulpar assegura o desenvolvimento radicular normal (TORNECK, 1970; DAS et al., 1997).

A busca da manutenção da vitalidade e integridade pulpar tem sido um fato corriqueiro na odontologia moderna. Tentativas de proteção pulpar direta ocorrem desde o século XVIII. Vários materiais têm sido propostos com esta finalidade, apresentando qualidades favoráveis e desfavoráveis que devem ser consideradas.

O primeiro autor a intentar conservar viva uma polpa exposta parece ter sido em 1756, protegendo-a com uma placa de ouro côncava e sobre esta colocando o material restaurador (PFAFF, 1956).

Ainda do século passado, e tendo perdurado por muito tempo, um procedimento técnico bastante utilizado foi a mumificação pulpar, onde primeiramente a polpa coronária era desvitalizada através do trióxido de arsênico e em seguida removida, sendo que a polpa radicular remanescente era então fixada com formaldeído. A mumificação pulpar tornou-se obsoleta e em desuso pois, a substância utilizada na época era citotóxica e produzia destruição das células endoteliais, congestão vascular, hemorragia, degeneração dos filetes nervosos e necrose pulpar, além de provocar danos aos tecidos periapicais.

O avanço mais promissor na manutenção da polpa veio com HERMANN, em (1920), quando foi introduzido o hidróxido de cálcio na terapia endodôntica, o que marca o início de uma nova era para o tratamento da polpa dental.

Com as pesquisas de ORBAN (anos 40 e 50), ficou demonstrado que a polpa dental é um tecido conjuntivo semelhante em arranjo e células aos demais tecidos conjuntivos do organismo. Daí tornou-se claro que a polpa pode se reparar, como qualquer outro tecido do organismo, quando a agressão é removida (DEZAN JR et. al., 1998)

A realização do tratamento conservador da polpa é uma das principais e mais freqüentes atividades diárias do clínico geral. Por este motivo compreende-se a importância e o interesse sempre crescente pela evolução dos estudos em torno deste assunto (LEONARDO et. al., 1982). 
Alguns resultados práticos para realização da pulpotomia podem ser enumerados (AYDOS, 1985) entre os quais:

a) Profilático - a permanência da polpa viva e sadia é certeza de saúde periapical;

b) Biológico - permite a complementação da rizogênese em dentes jovens, cujas polpas foram atingidas pela evolução da cárie, traumatismos dentários, etc;

c) Técnico - tratamento mais rápido e tecnicamente mais fácil diante de dificuldades cirúrgicas intransponíveis, como a complexa anatomia interna;

d)Econômico - A pulpotomia é rápida e menos dispendiosa do que o tratamento endodôntico radical.

A polpa dental exposta possui a capacidade de reparo quando devidamente protegida e quando a infiltração e a contaminação bacteriana conseguem ser evitadas (COX et al., 1982 e 1985).

O sucesso da terapia conservadora da polpa vital depende diretamente da estratégia de tratamento (TZIAFAS et al., 2000), incluindo:

1. Procedimentos operatórios para remoção de injúrias, controle de infecção e isolamento do complexo dentina-polpa de injurias adicionais;

2. Modalidades de tratamento (modo de aplicação do biomaterial capeador) para estimular o mecanismo de resposta dentinogênica especifica, e;

3. Restauração da cavidade para proteção da área tratada contra infilração bacteriana.

De acordo com os sinais clínicos, como sangramento de coloração normal, consistência do tecido pulpar e facilidade de hemostasia, sugerem condições favoráveis do tecido (ROCHA et al., 2002).

A partir desta época, inúmeros materiais e métodos têm sido utilizados sobre a polpa dental exposta e/ou o complexo dentinopulpar, dentre os quais destaca-se, numa breve revisão, óxido de zinco e eugenol, proteína osteogênica, corticosteróide, agregado 
trióxido mineral (MTA)/ cimento portland, como forma de tratamento conservador da polpa dental (HOLLAND et al., 2001).

\section{I.4.1. - Hidróxido de cálcio}

Há no mercado formulações de cimentos que contém hidróxido de cálcio em sua composição, dentre eles podemos citar o Life (Kerr) e o Dycal (Cauk). É comum, quando se recorre à literatura pertinente, os autores se referirem aos cimentos que contêm hidróxido de cálcio sem uma discriminação mais detalhada, fato que pode confundir o leitor e este achar que o material em estudo é o $\mathrm{Ca}(\mathrm{OH})_{2}$ quimicamente puro (PA).

Quanto aos cimentos à base de $\mathrm{Ca}(\mathrm{OH})_{2}$, seu uso é preconizado a partir de quantidades iguais de pasta base e catalisador, mas onde estaria o $\mathrm{Ca}(\mathrm{OH})_{2}$ ? $\mathrm{Na}$ base ou no catalisador? Para LIFE na pasta base e para DYCAL, no catalisador. Em trabalhos experimentais de HOLLAND et al., (1978 e 1981) testaram o $\mathrm{Ca}(\mathrm{OH})_{2}$ P.A. e outros cimentos à base de hidróxido de cálcio como o Dycal. Foi verificado que o $\mathrm{Ca}(\mathrm{OH})_{2}$ P.A. apresentou melhor resultado que os cimentos, e que para o Dycal quando continha maior quantidade de catalisador o resultado foi mais favorável (HOLLAND et al., 1981).

SELTZER \& BENDER (1975), atribuem ao $\mathrm{Ca}(\mathrm{OH})_{2}$ a propriedade de calcificar a polpa, onde observa-se a presença de fragmentos de dentina causando a mineralização da polpa. HOLLAND et al., (1978), verificaram vários casos de calcificação pulpar induzida por fragmentos de dentina. $\mathrm{O} \mathrm{Ca}(\mathrm{OH})_{2}$ não apresenta capacidade de penetração em profundidade na matriz extracelular, portanto não induz calcificação em profundidade (HOLLAND et al., 1996).

\section{I.4.2. - Óxido de zinco e eugenol (OZE)}

O cimento de óxido de zinco e eugenol (OZE) é um material empregado por alguns como um capeador pulpar indireto e direto. O OZE seria ideal para a manutenção da vitalidade pulpar quando manipulado com quantidades mínimas de eugenol, apresentando resultados semelhantes aos do $\mathrm{Ca}(\mathrm{OH})_{2}$.

Verificou-se na literatura que o OZE contém grande quantidade de eugenol que não reage com o óxido de zinco. O eugenol, ligeiramente solúvel em água, é um material que em concentrações elevadas, acima de 10-3mol/l, tem alto poder lesivo; 
quando a concentração é de 10-5-10-4mol/l apresenta ação inibidora da síntese de prostaglandinas e inibição reversível da atividade sensorial de fibras nervosas, apresentando, pois, ação antiinflamatória e analgésica.

O OZE é excelente para ser empregado sobre a dentina (capeamento indireto), pois, além de apresentar atividade bactericida, é analgésico e antiinflamatório. O OZE aplicado diretamente sobre a polpa (capeamento direto), parece não cumprir as funções de manter a viabilidade deste tecido e promover uma reparação da exposição por dentina HOLLAND, (1981); HOLLAND, (1996).

\section{I.4.3. - Formocresol}

O formocresol, formaldeído ou glutaraldeído tem a função de fixar tecidos (TSAI \& TSENG, 1993). As áreas não-fixadas, mas que sofreram ação do medicamento, permanecem em situação de inflamação crônica (DOYLE et al., 1962).

Embora a técnica de pulpotomia tratada com esta substância seja bastante utilizada, gera controvérsias devido à toxicidade do material. Existem relatos sobre efeitos adversos obtidos com o formocresol (BLOCK et al., 1983; CAMBRUZZI \& GREENFELD, 1983;ABRAMS et al., 1992). Um dos principais problemas, que não é percebido clinicamente, é a sua distribuição sistêmica. Não é interessante que um material que fixe tecidos e induza a inflamação se distribua por todo o organismo (HATA et al., 1989; ARAKI et al., 1993).

\section{I.4.4. - Proteína osteogênica ou osteomorfogenética}

Proteína osteogênica (OP) ou osteomorfogenética (BMP) corresponde a um subgrupo de uma família grande de proteínas não-colagênicas conhecidas como Fator de Transformação de Crescimento $\beta$ (TGB- $\beta$ ). Proteínas desta família estão implicadas em atividades envolvendo diferenciação celular, morfogênese tecidual, regeneração e reparo (RUTHERFORD, 1994; ZHU et al., 2000).

Estas proteínas são encontradas na matriz óssea cortical, dentina, e podem estimular células mesenquimais indiferenciadas a se diferenciarem em condroblastos e osteoblastos. Devido a ação indutora da formação de tecido ósseo, as BMPs têm sido usadas em pesquisas para tratamento de defeitos ósseos (GAO, 1995). 
Ameloblastos e odontoblastos também têm habilidade de sintetizar BMP que produz proliferação e diferenciação do epitélio odontogênico e células mesenquimais. Existem pelo menos 3 tipos de proteínas com capacidade de estimular formação de dentina reparadora (BMP-1, -2, e -4).

Observaram que a quantidade de dentina formada é diretamente proporcional à dose de BMP aplicada. Verificaram também que a BMP-1 associada ao colágeno tipo I preservam a vitalidade pulpar e induzem a formação de dentina reparadora em exposições pulpares grandes em dentes de macacos (RUTHERFORD et al., 1993).

Pesquisas com várias associações prosseguiram: Realizou-se capeamento pulpar em dentes de cães com BMP-2, -4 e associadas a uma matriz de colágeno tipo I. Após setenta dias foi verificada presença de dentina tubular e osteodentina, além de observar-se a diferenciação de odontoblastos em polpas seccionadas (NAKASHIMA, 1994).

Capearam polpas de cães com BMP pura, ou associada com dentina ceramificada (CD), e CD isoladamente. Após quatro semanas houve formação de ponte de dentina reparativa no grupo BMP/CD sem sinais de inflamação. Parece claro que a proteínas BMPs surgiram como promotoras de formação dentinária, mas novos estudos são necessários a fim de se determinar a qualidade da proteção oferecida ao remanescente pulpar pela osteodentina formada (GAO et al., 1995).

\section{I.4.5. - Corticosteróides}

Os corticosteróides são substâncias anti-inflamatórias do grupo de agentes químicos imunodepressores não específicos. Podem por isso suprimir algumas reações de hipersensibilidade. Atribui-se esta atividade dos corticosteróides à sua ação estabilizadora sobre a membrana dos lisossomas (ZANINI \& OGA, 1985).

Para a escolha do corticosteróide, atualmente o arsenal farmacêutico é constituído de uma grande quantidade de opções de produtos. A droga deve ser empregada em associação a antibiótico, para evitar contaminação indesejada, e apresentar alto poder de penetração. A solução otológica otosporin é utilizada tanto para exposição pulpar direta quanto para aplicação diretamente em dentina após preparos cavitários de rotina em dentística operatória(HOLLAND et al., 1996). 


\section{I.4.6. - Agregado de Trióxido Mineral (MTA)}

Foi idealizado na Faculdade Norte Americana de Loma Linda, Califórnia, pelo professor TORABINEJAD et al., (1995), com o intuito de selar a comunicação entre o dente e a superfície externa periodontal. Esse novo material foi aprovado em 1998 pela US Food and Drug Administration (FDA), associação norte americana de administração de alimentos e drogas (LEE et al., 1993; ABEDI \& INGLE, 1995; FORD et al., 1996; TORABINEJAD \& CHIVIAN, 1999; SCHWARTZ et al.,1999).

Desde as primeiras descrições na literatura, o MTA tem sido usado em procedimentos cirúrgicos e não cirúrgicos, incluindo capeamento pulpar direto, apexogênese, apecificação, reparo de perfurações em raízes (LEE \& TORABINEJAD, 1993). As trepanações configuram um dos mais desagradáveis acidentes técnicos que podem ocorrer durante os tratamentos endodônticos (SELTZER et al., 1967; INGLE \& TAINTOR, 1985).

Existem também as perfurações ocasionadas durante o preparo para instalação de pinos intra-radiculares (BEHNIA et al., 2000). Dentre os materiais seladores pesquisados e utilizados em perfurações das paredes do canal radicular temos o amálgama, guta-percha, cimentos provisórios, hidróxido de cálcio, resinas compostas, cimentos de ionômero de vidro e mais recentemente, o MTA (TORABINEJAD et al., 1995; RAFTER et al., 2002; WELDON et al., 2002) que tem se mostrado satisfatório quanto às propriedades físicas e biológicas.

O MTA é composto de um pó que pode ser branco ou cinza, que consiste de partículas hidrofílicas, cujos principais componentes são silicato tricálcico, aluminato tricálcico, óxido tricálcico e óxido de silicato, além de outros óxidos minerais. Parece possuir qualidades superiores em relação à capacidade de selamento, quando comparado a outros materiais usados para esse fim, e suas características de biocompatibilidade, bem como a sua capacidade de induzir a formação de cemento, mesmo quando extruído nos tecidos periodontais indicam que esse material pode ser utilizado com sucesso em casos de perfurações radiculares (PITT FORD et al., 1996; HOLLAND et al., 2001).

Em estudo comparativo falava-se da superioridade do MTA em alguns aspectos, mesmo quando imerso em fluido ele não perdia a capacidade seladora na região do canal. Mostrou ser superior ao amálgama (PITT FORD et al., 1995). 
Esse pó é constituído de pequenas partículas que se solidificam na presença de água (BUSATO et al., 2000).

LEE \& TORABINEJAD (1993) mostraram, em estudo in vitro, que o MTA tem a capacidade de evitar a infiltração marginal maior que o cimento de óxido de zinco e eugenol e o amálgama. Além disso, adapta-se às paredes de dentina mais facilmente do que outros materiais, necessitando menor força de condensação para adaptação (ABEDI \& INGLE, 1995; FORD et al., 1996). QUEIROZ et al., (1997) verificaram in vitro menor infiltração marginal do MTA quando comparado ao IRM, ionômero de vidro e amálgama com verniz em apecificações de dentes humanos extraídos.

Um material odontológico para ser utilizado em procedimentos clínicos deve apresentar uma elevada biocompatibilidade. Várias pesquisas analisaram a citotoxicidade, mutagenicidade e reação tecidual na presença do MTA, onde os pesquisadores concluíram que esse material é altamente biocompatível com os tecidos periodontais e pulpares (TORABINEJAD et al., 1995; FORD et al., 1996).

\section{I.5. - As bases para desenvolvimento do compósito de colágeno com silicato e hidroxiapatita como material para endodontia}

\section{I.5.1. - Colágeno}

É a principal proteína estrutural dos tecidos dos animais vertebrados, sendo encontrada abundantemente no tecido conjuntivo, mais especificamente, na pele, cartilagem, ossos, tendões e no dente. As diferentes propriedades destes tecidos são em parte devido ao resultado de diferentes organizações das fibras de colágeno. Sua principal característica é a formação de fibras insolúveis com alta força elástica e grande resistência à tração, sendo a função estrutural a mais importante.

Até a década de 1980, o emprego de colágeno era restrito à produção de fios cirúrgicos, quando teve um aumento considerável em aplicações mais nobres que vão desde o revestimento de próteses vasculares (GRISTINA, 1987), até suporte para orientação do crescimento celular (BURET et al., 1991).

No novo conceito de biomateriais, estes não devem servir, apenas, para o preenchimento de espaços (LANGER, 1993), mas também devem estimular uma 
resposta biológica quando implantados. Em virtude dessas propriedades o colágeno possui uma posição privilegiada como biomaterial em diversas aplicações como, reconstrução de tecidos moles (CHEN et al., 2000), revestimento de queimaduras e outras lesões (TABATA, 2000), suporte para crescimento de nervos periféricos (PROKOP, 1997), orientador de tecidos em desenvolvimento (GOISSIS et al., 2003) e como agente hemostático (KAWAI et al., 2000). .Além do que, pode ser utilizado sob diversas formas como: membranas, esponjas, géis, pós, filmes, tubos, etc (MA et al., 1999).

O colágeno é amplamente utilizado como matéria prima na produção de biomateriais devido a suas propriedades naturais (MODAK et al., 1987) que incluem: baixa resposta imunológica mesmo quando extraído de fonte heteróloga; baixo índice de alergenicidade (cerca de $2 \%$ para colágeno heterólogo) que pode ser reduzido mais ainda pela remoção dos telopeptídeos $\mathbf{N}$ e $\mathbf{C}$-terminais, tornando-o altamente biocompatível; biodegradabilidade (susceptível à ação de colagenases); habilidade em promover crescimento celular; propriedades hemostáticas (ativação do processo de coagulação) e susceptível a modificações químicas (GOISSIS et al., 1996).

Atualmente são conhecidos vinte e seis tipos de colágeno, dentre eles, o colágeno tipo I (Figura 11) é o que vem sendo mais estudado por ser o tipo mais abundante do tecido conjuntivo.
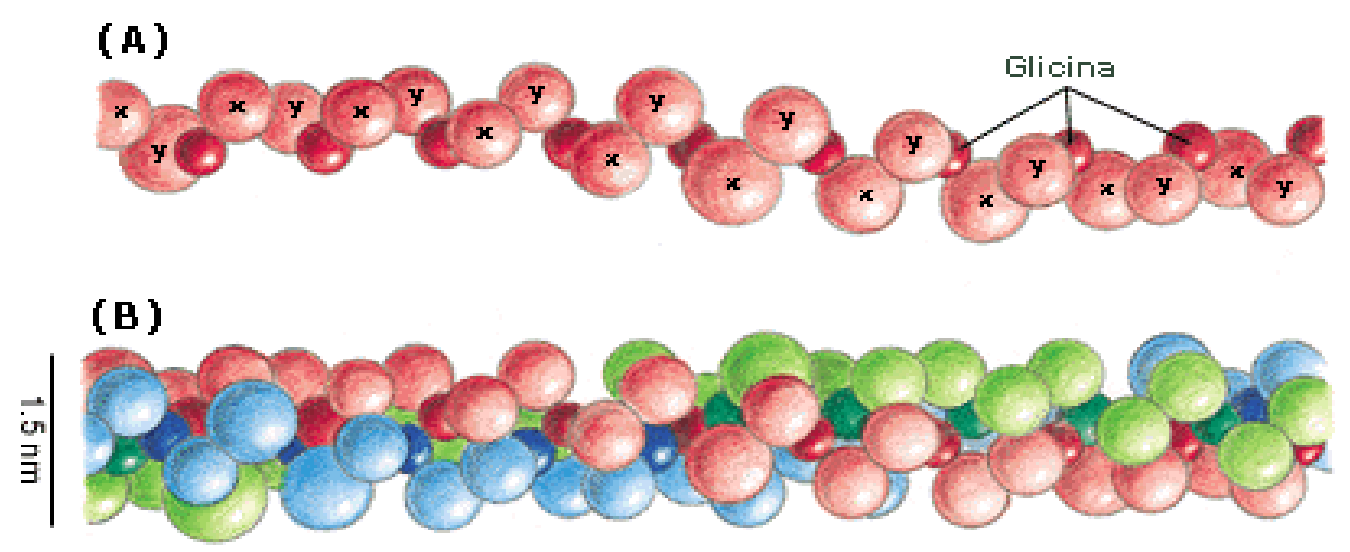

FIGURA 11. - Representação esquemática das estruturas do colágeno.

A estrutura da hélice tripla é possível graças a sua seqüência primária peculiar, na qual o triplete (Gly-X-Y) se repete ao longo das cadeias polipeptídicas. Os resíduos X e Y podem ser Pro ou Hyp, respectivamente, e o restante, cerca de dois terços, 
corresponde a outros aminoácidos que são essenciais para a organização do colágeno em fibras. A ausência da cadeia lateral na Gly favorece o enovelamento das cadeias, com estes resíduos localizando-se no interior da hélice onde não há espaço para cadeias laterais (NIMNI, 1988).

Vários modelos foram propostos a partir de estudos por microscopia eletrônica para explicar como o tropocolágeno organiza-se para formar a microfibrila. O modelo mais aceito foi proposto por SMITH, (1968) onde a associação entre moléculas de tropocolágeno apresenta uma periodicidade denominada $\mathrm{D}$, cuja origem está relacionada à interação entre as cadeias laterais projetadas externamente quando duas moléculas encontram-se em justaposição paralela. Estas interações moleculares, particularmente àquelas entre cadeias laterais carregadas e entre grandes cadeias laterais hidrofóbicas, são muito favorecidas quando as moléculas de tropocolágeno próximas estão mutuamente justapostas ao longo de um eixo longitudinal deslocadas umas das outras de um quarto de seu comprimento (680 Å) em relação à molécula vizinha. Este modelo descrito é denominado de quarto alternado pentafibrilar (Figura 12a) (NIMNI, 1988). Cada período D é composto de "bandas" ou zonas, uma contendo mais moléculas na seção transversal do que a outra, ou seja, para cada cinco moléculas na zona "Overlap” do período D, há quatro na zona “Gap”, como mostra na (Figura 12b).

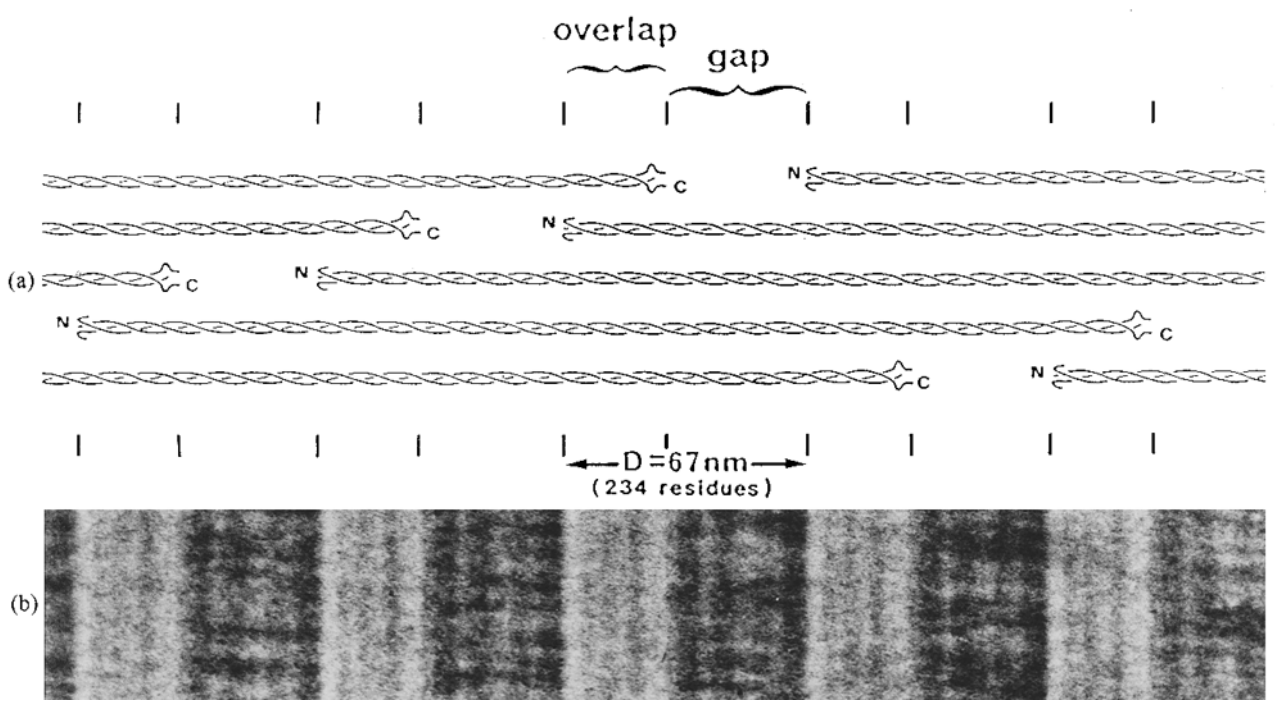

FIGURA 12. - Organização estrutural das moléculas de tropocolágeno de acordo com o modelo de Smith, para a formação da microfibrila: a) modelo quarto alternado pentafibrilar; b) periodicidade da microfibrila. 
Formadas as microfibrilas, inicia-se o processo de agregação denominado fibrilogênese (CHAPMAN et al., 1990), para formar fibrilas insolúveis. Esse processo, in vitro, é dependente da temperatura, força iônica e $\mathrm{pH}$, e as fibrilas reconstituídas possuem as características estruturais idênticas àquelas formadas in vivo (GALLOP et al., 1967). Para o colágeno tipo I a formação de fibras ocorre em $\mathrm{pH}$ 7,0, ou seja, é o pH no qual tem-se a máxima interação eletrostática entre as moléculas de tropocolágeno. A macromolécula de colágeno é um filamento semiflexível de 300nm de comprimento e 1,5nm de diâmetro, sendo sua estrutura fundamental formada por uma unidade monomérica denominado tropocolágeno.

A molécula de tropocolágeno é formada por duas cadeias idênticas denominadas de $\alpha_{1}$, possuindo cada uma cerca de 1055 resíduos de aminoácidos e uma cadeia diferente denominada de $\alpha_{2}$, possuindo cerca de 1029 resíduos. Nas extremidades da estrutura helicoidal do tropocolágeno existem pequenas regiões de cadeias polipeptídicas não helicoidais denominadas telopeptídeos, com 16 e 25 aminoácidos nas regiões $\mathbf{N}$ e $\mathbf{C}$-terminais, respectivamente(CHAPMAN et al., 1990). As cadeias formadoras do tropocolágeno apresentam-se na forma helicoidal e enrolamse umas nas outras formando uma hélice tripla (Figura 11) (GALLOP et al., 1967).

Estas forças também são importantes para a interação entre as moléculas de tropocolágeno para formar a microfibrila, que é a menor unidade estrutural do tecido conjuntivo.

Com essa distribuição periódica de resíduos de aminoácidos carregados ocorre uma maior interação entre as moléculas de tropocolágeno a pH 7,4, tem-se neste $\mathrm{pH}$ a resultante de carga na molécula sendo zero. Porém, a distribuição de cargas na molécula de colágeno pode ser modificada por reações químicas específicas nos aminoácidos carregados, para produzir matrizes carregadas negativa ou positivamente (VEIS 1982; LACERDA, 1997; LACERDA et al., 1997).

Um outro processo interessante para a preparação de materiais de colágeno carregados negativamente a pH 7,4 é a hidrólise seletiva dos grupos carboxamidas dos resíduos de aminoácidos asparagina (Asn) e glutamina (Gln) presentes nas cadeias $\alpha$ do tropocolágeno (SINGH et al., 1995). Esta modificação conduz a um aumento total de até 125 cargas por unidade de tropocolágeno. 
Essas modificações químicas em matrizes colagênicas ou associações com outros compostos permitem a implementação de diferentes propriedades físico-químicas e estruturais, possibilitando assim, novas aplicações na área de biomateriais.

Outra vantagem é sua fácil obtenção, este pode ser proveniente de diversas fontes, tais como tendões, serosas (bovina, porcina), pericárdio entre outras, que estão facilmente disponíveis no mercado.

\section{I.5.2. - Cimento Portland Branco (CPB) - (NBR 12989)}

WEIDMANN et al.(1994) estudando os componentes do cimento Portland, relatoram que o termo “cimento" é genérico e é aplicado a todos os aglutinantes que são usados no concreto. Os constituintes do cimento Portland são minerais, que existem como soluções de multicomponentes sólidos. Os solutos ou impurezas são importantes porque podem afetar as estruturas do cristal e ou sua capacidade de reagir. Mesmo assim, é comum tratar os principais constituintes como compostos químicos e rotulá-los como se fossem misturas de óxidos, usando uma abreviatura. Isto envolve substituir a fórmula química usual por um óxido com uma letra só, tais como: $\mathrm{CaO}, \mathrm{SiO}_{2}, \mathrm{Al}_{2} \mathrm{O}_{3}$, $\mathrm{Fe}_{2} \mathrm{O}_{3}, \mathrm{H}_{2} \mathrm{O}, \mathrm{SO}_{3}$.

O cimento Portland tem vários componentes, mas, os principais são: silicato tricálcico (3CaO. $\left.\mathrm{SiO}_{2}\right)$, silicato dicálcico $\left(2 \mathrm{CaO} . \mathrm{SiO}_{2}\right)$, aluminato tricálcico (3CaO. $\mathrm{Al}_{2} \mathrm{O}_{3}$ ), aluminoferrato tetracálcico (4CaO. $\left.\mathrm{Al}_{2} \mathrm{O}_{3} \cdot \mathrm{Fe}_{2} \mathrm{O}_{3}\right)$, sulfato de cálcio dihidratado ( $\left.\mathrm{CaO} . \mathrm{SO}_{3} \cdot 2 \mathrm{H}_{2} \mathrm{O}\right)$, óxidos alcalinos e outros constituintes. Os componentes básicos do cimento Portland são semelhantes (VAN VLACK, 1973; CALLISTER, 1991; WEIDMANN et al., 1994; CALLISTER, 2002). Pequenas diferenças podem ser notadas dependendo do fabricante e da localização da fonte de extração mineral.

O Cimento Portland Branco se diferencia dos demais cimentos por coloração, e está classificado em dois subtipos: estrutural e não estrutural. O estrutural é aplicado em concretos brancos para fins arquitetônicos, com classes de resistência 25MPa, 32MPa e 40MPa, similares às dos demais tipos de cimento, que superam os valores normativos de resistência à compressão que são de 14Mpa, 24Mpa e 34Mpa para 1, 3 e 7 dias de idade respectivamente. Já o não estrutural não tem indicações de classe e é aplicado, por exemplo, em rejuntamento de azulejos e em aplicações não estruturais. Pode ser utilizado nas mesmas aplicações do cimento cinza. A cor branca é obtida a partir de 
matérias-primas com baixos teores de óxido de ferro e manganês, em condições especiais durante a fabricação, tais como resfriamento e moagem do produto e, principalmente, utilizando o caulim no lugar da argila. O índice de brancura deve ser maior que 78\%. Adequado aos projetos arquitetônicos mais ousados, o cimento branco oferece a possibilidade de escolha de cores, uma vez que pode ser associado a pigmentos coloridos (VOTORANTIN CIMENTOS, 2005).

A avaliação química dos elementos presentes no MTA e em duas amostras de cimento Portland, uma do tipo Itaú (Companhia Portland de cimento Itaú, Itaú de Minas, MG, Brazil), e outra do tipo Liz (Companhia Portland de cimento Liz, Vespasiano, MG, Brazil), feita com um Espectrômetro de Fluorescência de de Raios-X (Carl Zeiss, Mod. VRA-30, Alemanha), mostrou que o cimento Portland contém os mesmos elementos químicos que o MTA, exceto o elemento bismuto na forma de óxido. Na análise química do cimento Portland os componentes estavam presentes de acordo com as porcentagens médias seguintes: $\mathrm{CaO}$ (58\%), $\mathrm{SiO}_{2}$ (17.7\%), $\mathrm{Al}_{2} \mathrm{O}_{3}$ (4.5\%), $\mathrm{MgO}$ (3.3\%), $\mathrm{SO}_{3}$ (3.0\%), $\mathrm{Fe}_{2} \mathrm{O}_{3}(2.9 \%), \mathrm{K}_{2} \mathrm{O}$ (0.9\%), $\mathrm{Na}_{2} \mathrm{O}(0.2 \%)$ (ESTRELA et al., 2000).

\section{I.5.3. - Hidroxiapatita (HA)}

O interesse pela HA como um biomaterial, está relacionado com o fato desta ser a principal fase mineral encontrada no tecido ósseo e ter alta biocompatibilidade (OGUCHI, 1995). Suas aplicações estendem-se desde a ortopedia e traumatologia para correções buco maxilo faciais; traumatismos raquimedulares e coluna cervical; tumores músculo-esqueléticos, entre outras aplicações (AOKI, 1991) e na odontologia, nos casos de doenças periodontais, implantes dentários, preenchimento de cavidades císticas ou mesmo aumentos do rebordo ósseo alveolar, além de outras aplicações (LEGEROS, 1988 - Tabela 2). 
TABELA 2. - Formas das Hidroxiapatitas usadas em Medicina e Odontologia (AOKI, 1991).

\begin{tabular}{|ll|}
\hline \multicolumn{1}{|c|}{ USOS } & \multicolumn{1}{c|}{ FORMAS } \\
\hline \hline Matriz ou suporte para crescimento & grãos, porosa \\
ósseo & \\
Osso artificial & grãos, densa ou porosa \\
Cimento ósseo & pó com PMMA \\
Articulações artificiais & metal recoberto com HÁ \\
Próteses vasculares & Densa \\
Próteses traqueais & porosa ou densa \\
Terminais percutâneos & Densa \\
Sistema de liberação lenta & densa, pó \\
\hline
\end{tabular}

A hidroxiapatita (HA) faz parte de um grupo de minerais chamados apatitas (VIDEAU \& DUPUIS, 1991), e possui fórmula química $\mathrm{Ca}_{10}\left(\mathrm{PO}_{4}\right)_{6}(\mathrm{OH})_{2}$

Como material de implantes pode ser obtida por desproteinização de tecido ósseo (PARK, 1984), ou por tratamento hidrotérmico de corais (WHITE \& SHORS, 1986). Pode ser obtida também por processos sintéticos tais como, precipitação a partir de soluções aquosas (OSAKA et al.,1991; JARCHO et al., 1976) ou reações no estado sólido (VIDEAU \& DUPUIS, 1991).

A HA ultimamente é muito utilizada nas áreas médicas e odontológicas, no entanto sua utilização vem sendo feita na forma particulada e um dos maiores problemas de sua utilização nesta forma é sua dispersão para zona de tecidos moles, causando problemas, incluindo perdas das partículas.

Recentemente, vários autores recomendam a combinação de HA particulada com uma série de materiais, tais como elastina (ROVIRA et al., 1993), quitosana (ITO 1991), colágeno (KAZIM et al., 1992), entre outros, facilitando o manuseio e a adaptação adequada do material na medida em que minimiza o desalojamento das partículas. Vários autores sugerem o colágeno (SERRE et al., 1993; HEMMERLE et al., 1995) para este fim, pois este material constitui-se em um agente de união biocompatível e reabsorvível, responsável pela prevenção da migração das partículas cerâmicas, até a incorporação pelos tecidos do paciente.

Muitos trabalhos mostram que o colágeno não é só capaz de promover a proliferação de células do tecido conjuntivo, tais como fibroblastos na confecção de novos tecidos, mas também, (SERRE et al., 1993) em testes "in vitro”, verificou que quando se combinava HA com uma esponja de colágeno, na presença de cultura de 
osteoblastos, estes migravam em direção a esponja e induziam a formação de uma matriz de calcificação, com a presença de cristais de HA no interior da matriz.

\section{I.6. - Estudo da influência do Mercúrio (Hg) e do Chumbo (Pb) frente à obtenção de um biomaterial}

Na odontologia, uma das preocupações na obtenção de um biomaterial gira em torno da quantidade de metais pesados como $\mathrm{Hg}$ e $\mathrm{Pb}$. Este material quando caracterizado, como por exemplo pela análise de EDX, podem detectar a presença dos mesmos que quando comparados com a literatura poderão nos indicar índices de contaminação pelo mercúrio (mercurismo) e pelo chumbo (saturnismo ou plumbismo).

Muitas doenças têm como causa a contaminação por mercúrio (Hg) (WINDHOLZ et al., 1994; SAQUY et al., 1997), que pode ter a sua determinação em fluidos biológicos para fins de diagnóstico e de controle, em líquidos tais como urina, saliva e sangue.

Na cavidade bucal pode provocar o sangramento gengival, a perda do osso alveolar, a perda dos dentes, o excesso de salivação, o mau hálito, gosto metálico, leucoplasias, estomatites e pigmentação nos tecidos (PÉCORA et al., 2002).

O chumbo $(\mathrm{Pb})$, mesmo em baixas concentrações, é estranho ao metabolismo humano, podendo intervir em diversas partes do metabolismo e causar intoxicações. Os principais efeitos dos compostos de chumbo no sistema nervoso por exposição química são as encefalopatias com irritabilidade, cefaléia, tremor muscular, alucinações, perda de memória e da capacidade de concentração (LARINI, 1993). Esses sintomas podem evoluir até o delírio, convulsões, paralisias e coma. Dados experimentais revelam que danos causados pelo chumbo podem afetar funções da memória e do aprendizado em todos os ciclos da vida. Pode afetar o metabolismo do osso no período da menopausa na mulher, contribuindo para o desenvolvimento da osteoporose e no homem quanto à função reprodutora influindo na morfologia e número dos espermatozóides (IPSC, 1995).

Os limites de tolerância biológicos (LTB) propostos para intoxicação profissional pelo metal (IPCh) variam historicamente de país a país (CORDEIRO, 1995). Os LTB são fixados de acordo com informações provenientes das indústrias e de investigações científicas e devem estar relacionadas com a política de saúde ocupacional do país. Países que não desenvolveram seus próprios LTB costumam adotar 
critérios definidos por outras nações. Este é o caso do Brasil. Regulamentadas pela Portaria $n^{0}$ 12, de 06/06/83, apresentada pela Secretaria de Segurança e Medicina do Trabalho. 


\section{II.- OBJETIVO}

Este trabalho teve como objetivo preparar e caracterizar um material compósito de colágeno com silicatos e hidroxiapatita com a seguinte finalidade:

- Utilizá-lo futuramente em odontologia, mais especificamente na Endodontia para capeamento pulpar direto e pulpotomia como tratamento endodôntico preventivo em nível de Câmara Pulpar.

- Minimizar o custo final do tratamento em relação aos tratamentos convencionais, tendo em vista que a preparação do compósito proposto é bastante acessível do ponto de vista econômico. 


\section{III.- PARTE EXPERIMENTAL}

Fez-se o experimento com utilização de materiais como o Cimento Portland Branco adquirido comercialmente, o Colágeno Aniônico tipo I obtido a partir de serosa porcina (GOISSIS, 1994), a Hidroxiapatita Sintética (método de JARCHO, 1976), já caracterizados e produzidos conforme protocolo do Grupo de Bioquímica e Biomateriais do Instituto de Química de São Carlos (USP) - Figura 13.

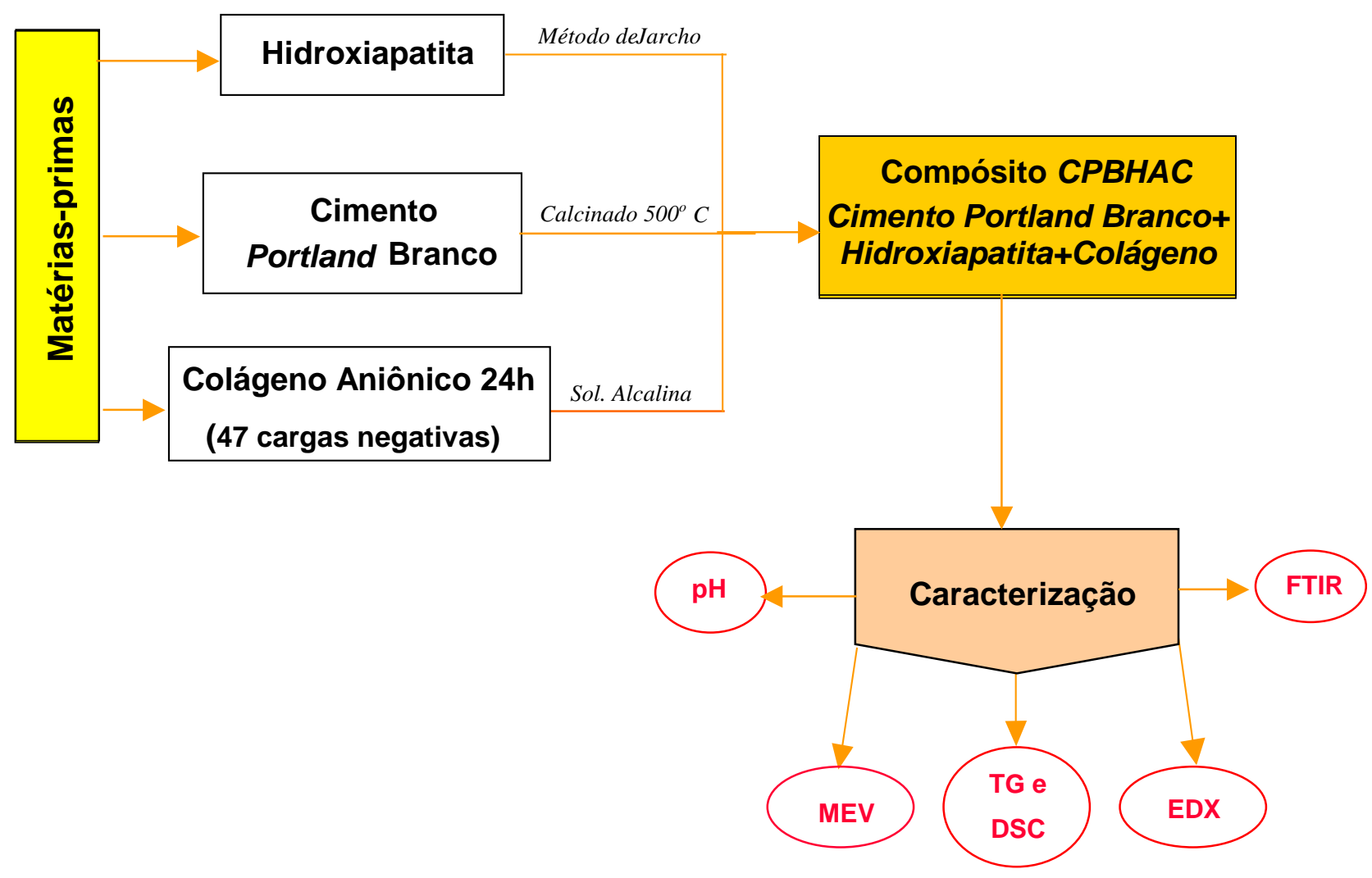

FIGURA 13. - Esquema representativo da parte experimental

\section{III.1. - Preparação dos materiais}

\section{III.1.1. - Colágeno Aniônico}

Utilizou como matéria prima, serosa intestinal porcina de aproximadamente cinco anos de idade, em forma de fitas, purificada como para a extração de fio de sutura "cat-gut", que foi mantida congelada por volta de $-5^{\circ} \mathrm{C}$ até a sua utilização. Após o 
descongelamento, o excesso de água da serosa foi removido com o auxílio de papel de filtro e em seguida picotada em pedaços de aproximadamente $1 \mathrm{~cm}$ de comprimento.

Esse material foi submetido a tratamento em solução aquosa alcalina contendo dimetilsulfóxido (6\%), cloretos e sulfatos de sódio, potássio e cálcio em pH próximo de 13 por um período de 24h. Posteriormente removeu-se os sais residuais, por lavagens sucessivas com solução de $\mathrm{H}_{3} \mathrm{BO}_{3}$ (3\%) e EDTA (0,3\%). Em seguida extraiu-se o colágeno com solução de ácido acético (pH 3,5), de tal forma que a concentração final de colágeno ficasse em torno de 1\%. Essa solução foi desaerada e estocada em frascos escuros à temperatura de $4^{\circ} \mathrm{C}$ (GOISSIS et al., 1994).

\section{III.1.2 - Cimento Portland Branco (CPB)- (NBR 12989)}

O Cimento Portland Branco (estrutural) foi obtido comercialmente e antes de seu uso foi calcinado de modo gradativo, variando-se a temperatura do forno de $100^{\circ} \mathrm{C}$ até $500^{\circ} \mathrm{C}$ para eliminação de compostos orgânicos. O CPB permaneceu em $500^{\circ} \mathrm{C}$ por um intervalo de 1 (uma) hora. Aguardou-se o resfriamento do forno até $100^{\circ} \mathrm{C}$, retirouse o material do forno e acondicionou-se em um dessecador.

\section{III.1.3 - Hidroxiapatita (HA)}

\section{III.1.3.1. - Síntese e resumo da técnica}

A síntese da hidroxiapatita foi feita seguindo o método de JARCHO, 1976.

Preparou-se uma solução $1,00 \mathrm{Mol} \mathrm{L}^{-1}$ de $\mathrm{Ca}\left(\mathrm{NO}_{3}\right)_{2} 4 \mathrm{H}_{2} \mathrm{O}$ com seu pH ajustado entre 11,0 e 12,0 com hidróxido de amônio concentrado (Solução I). Preparou-se a seguir uma solução de $\left(\mathrm{NH}_{4}\right)_{2} \mathrm{HPO}_{4}$ 0,60 Mol L ${ }^{-1} \mathrm{com} \mathrm{pH}$ ajustado entre 11,0 e 12,0 com hidróxido de amônia concentrado (Solução II).

A solução de cálcio (Solução I) foi vigorosamente agitada para homogeneizar a temperatura em todo o sistema e mantida sob fluxo constante de $\mathrm{N}_{2}$, para a total eliminação do $\mathrm{CO}_{2}$ no sistema. A solução de fosfato (Solução II) foi adicionada lentamente a solução de cálcio (Solução I), produzindo uma suspensão com precipitado de forma gelatinosa, que foi agitado durante 40 horas à temperatura ambiente, sempre sob fluxo constante de $\mathrm{N}_{2}$.

Após este tempo, deixou-se a suspensão decantar retirando o sobrenadante por meio de um sifão. A suspensão foi lavada com água deionizada e novamente decantada e sifonada. Esta operação foi repetida várias vezes até que o $\mathrm{pH}$ do sobrenadante se 
tornasse constante. A suspensão de HA formada foi centrifugada a 4000 rpm por 15 minutos a $20^{\circ} \mathrm{C}$ e em seguida filtrada em funil de Buchner e colocada em estufa à $90^{\circ} \mathrm{C}$ durante um período de 24 horas. Após este período a HA foi triturada em almofariz de porcelana e separada em peneiras de 60 e 100 mesh.

\section{III.1.4. - Compósitos}

As preparações dos materiais de estudo foram divididas em três grupos, sendo que o grupo 1 foi apenas a mistura do cimento Portland Branco com água. Já para obtenção dos compósitos (grupos 2 e 3), variou-se a proporção de HA e colágeno de modo a não obter somente um material mais homogêneo, como também, observar as possíveis mudanças na obtenção de um novo material que possa vir ser aplicado na Endodontia.

\section{III.1.4.1. Grupo 1 (CPBW)}

\section{- Cimento Portland Branco+Água}

Partindo-se da proporção de preparo para vários cimentos Portland que é de três partes do cimento para uma parte de água, adicionou-se 3,0 g de cimento Portland branco calcinado a $500^{\circ} \mathrm{C}$ em 1,0 mL de água.destilada. Com um bastão de vidro, misturou-se até obter o aspecto de pasta homogênea.

\section{III.1.4.2. Grupo 2 (CPBHAW)}

\section{- Cimento Portland Branco+Hidroxiapatita+Água}

Com o intuito de adicionar HA ao CPB, uma das alternativas foi diminuir a quantidade de CPB utilizado no preparo do grupo 1 e variar a quantidade de água para que se chegasse à consistência pastosa, pois caso contrário chegar-se-ia a uma mistura seca ou muito úmida. Após várias tentativas variando-se os componentes, adicionou-se 2,4 g de cimento Portland branco calcinado a $500^{\circ} \mathrm{C}$ a $0,6 \mathrm{~g}$ de HA sintética, com tamanho de partícula menor que 100 mesh, em 1,2 mL de água destilada. Com um bastão de vidro, misturou-se até aspecto homogêneo. 


\section{III.1.4.3. Grupo 3 (СPBHAC)}

\section{-Cimento Portland Branco+Hidroxiapatita+colágeno}

Como a quantidade de CPB e de HA no preparo do grupo 2 foi aceitável, manteve-se dos mesmos, porém como havia a intenção de se adicionar colágeno $24 \mathrm{~h}$ não poderia adicionar água e sim variar a proporção do mesmo na obtenção do Compósito, pois como é sabido há a liberação de água quando da mistura dos componentes. Adicionou-se, portanto, 2,4 g de cimento Portland branco calcinado a $500^{\circ} \mathrm{C}$ a 0,6 g de HA sintética, com tamanho de partícula menor que 100 mesh. Estes foram tamizados, peneirados (100mesh) e em seguida adicionados lentamente sobre 1,0 g de gel colágeno aniônico a 1 \%. Com um bastão de vidro, misturou-se vigorasamente até aspecto homogêneo e com consistência de pasta para que se pudesse obter as amostras com formato cilíndrico $(\phi=6 \mathrm{~mm} ; l=12 \mathrm{~mm})$ a partir dos moldes padronizados (ASTM F 451-86 ) - (Figura 14).

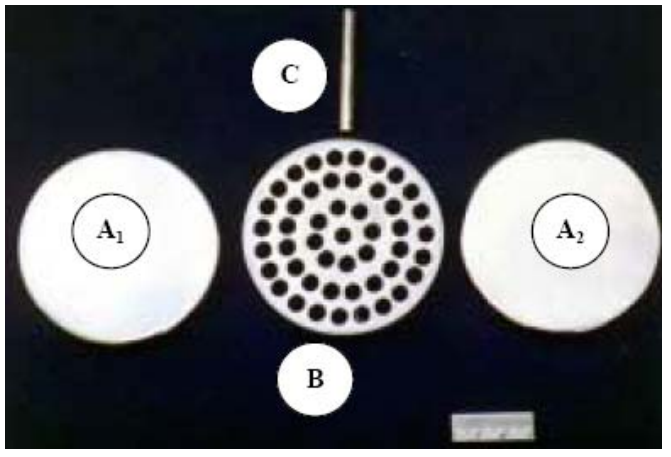

(a)

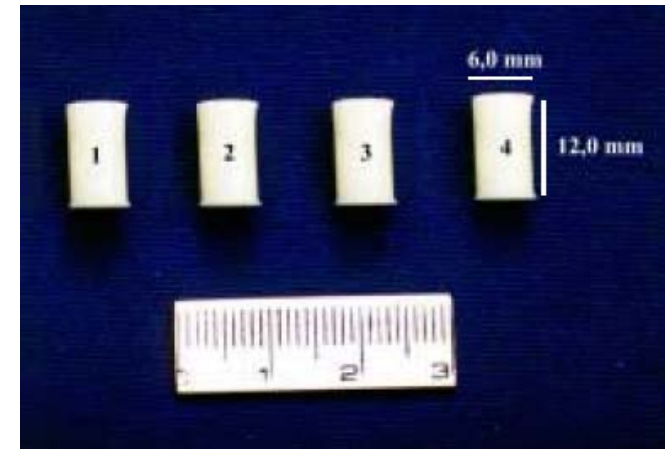

(b)

FIGURA 14. - (a) Sistema de moldagem dos cimentos $\left(\mathrm{A}_{1}\right.$ e $\mathrm{A}_{2}=$ placas lisas inferior e superior, respectivamente; $\mathrm{B}=$ placa perfurada; $\mathrm{C}=$ pino removedor); (b) Corpos de prova obtidos. 


\section{2. - Caracterização dos materiais}

\section{2.1. - Colágeno Aniônico}

\section{III.2.1.1. - Preparação das membranas}

As membranas para infravermelho foram preparadas a pH 3,5 pela adição de 4,0 mL de uma solução a $0,16 \%$ do gel de colágeno aniônico, em moldes de acrílico com 4,0 cm de diâmetro dando origem a membranas de cerca de $0,4 \mathrm{mg} / \mathrm{cm}^{2}$. Estas foram secas em capela de fluxo laminar a temperatura ambiente. Já para análise termogravimétrica e calorimetria exploratória diferencial, as membranas foram preparadas da mesma maneira mas na concentração de $4 \mathrm{mg} / \mathrm{cm}^{2}$.

\section{III.2.1.2. - Calorimetria Exploratória Diferencial (DSC)}

Cerca de 10,0 mg das membranas de colágeno foram colocadas em suportes de alumínio com fechamento hermético, tendo-se como referência o próprio suporte sem amostra. A análise foi feita em um equipamento DSC 2010 da TA Instruments. As medidas foram efetuadas numa razão de aquecimento de $10^{\circ} \mathrm{C} / \mathrm{min}$ em atmosfera de $\mathrm{N}_{2}$ e fluxo de $80 \mathrm{~mL} / \mathrm{min}$, sendo a padronização de temperatura e fluxo de calor feita previamente com índio (In).

\section{III.2.1.3. -Termogravimetria (TG)}

O registro e a curva termogravimétrica para as membranas foram obtidas com cerca de 10,0 mg das membranas de colágeno após serem hidratadas em tampão fosfato a pH 7,4, em atmosfera dinâmica de ar sintético em um equipamento TGA 2010, da TA Instruments, na faixa de temperatura de 25 a $900^{\circ} \mathrm{C}$, com razão de aquecimento de $10^{\circ} \mathrm{Cmin}^{-1}$.

\section{III.2.1.4.- Espectroscopia na região do infravermelho (FTIR)}

Os espectros de infravermelho foram obtidos com membranas a $0,4 \mathrm{mg} / \mathrm{cm}^{2} \mathrm{em}$ um aparelho BOMEM Modelo MB-102, no intervalo entre 400 à $4000 \mathrm{~cm}^{-1}$, com uma resolução de $4 \mathrm{~cm}^{-1}$. 


\section{III.2.2. - Cimento Portland Branco (CPB)}

Amostras de cimento Portland branco, depois de calcinadas a $500^{\circ} \mathrm{C}$, foram caracterizadas por TG, DSC (suporte não hermético) e FTIR da mesma forma que aquelas feitas para o colágeno (item III.2.1.1 a III.2.1.3), mas na forma de pó, e em pastilhas de $\mathrm{KBr}$ para FTIR.

Já para o CPB preparado com adição de água (Grupo 1), foram realizadas analises de MEV e EDX.

\section{III.2.3. - Hidroxiapatita sintética (HA)}

Efetuou-se análise de TG, DSC (suporte não hermético) e FTIR conforme descrito para o colágeno (item III.2.1.1 a III.2.1.3), mas na forma de pó, e em pastilhas de $\mathrm{KBr}$ para FTIR.

\section{III.2.4. - Compósitos: Grupos 2 e 3}

Para o grupo 2, foram efetuadas análise de MEV e EDX.

Para o grupo 3, foram efetuadas análise de TG, DSC (suporte não hermético), FTIR, MEV, EDX, radiopacidade e medidas de pH. As análises de TG, DSC (suporte não hermético), FTIR foram feitas conforme descrito para o colágeno (item III.2.1.1 a III.2.1.3), mas na forma de pó, e em pastilhas de KBr para FTIR.

\section{III.2.4.1. Microscopia Eletrônica de Varredura (MEV)}

As fotomicrografias de MEV das amostras dos grupos 1, 2 e 3, foram obtidas no Laboratório de Microscopia Eletrônica de Varredura (MEV) da Central de Análise Química e Instrumental (CAQI) do Instituto de Química da USP de São Carlos em equipamento LEO 440 com um detector Oxford, operando com feixe de elétrons de $20 \mathrm{KeV}$. As amostras foram recobertas com 30nm de ouro em um metalizador Balsers modelo SDC 050 e mantidas em dessecador até o momento da análise. As micrografias foram obtidas com aumentos variando de 300 a 5000x. 


\section{III.2.4.2. - Espectroscopia de Dispersão de Energia de Raios-X (EDX)}

Com a finalidade de verificar a presença de metais pesados nas preparações, foram obtidos os espectros de EDX. Para isso, utilizou-se um equipamento EDX LINK ANALYTICAL, modelo QX 2000, acoplado a um Microscópio Eletrônico de Varredura ZEISS, modelo DSM 960. As amostras foram preparadas como descrita para MEV, não sendo, porém recoberta com o metal ouro e sim com carbono (30 nm), utilizando-se um feixe de elétrons de $20 \mathrm{keV}$ e uma distância de $20 \mathrm{~mm}$ do canhão até a amostra.

\section{III.2.4.3. - Medidas do pH}

A - Utilizou-se papel indicador universal em tiras de plástico da escala quadricromática da marca Analiticals ${ }^{\circledR}$ Carlo Erba com possibilidade de medir o pH de 0 a 14.

Fez-se medições do pH à cada 30 minutos desde o tempo $(\mathrm{t}=0)$ até completar 3,5 horas do momento do preparo do Compósito.

B - Fez-se medidas com o pH-metro Micronal modelo B272 a partir do preparo das amostras do Compósito conforme descrito no item III.1.4. e diluição (1:50) em água destilada com medições do $\mathrm{pH}$ em intervalos de tempo como descrito anteriormente.

\section{III.2.4.4. - Verificação da Radiopacidade do Compósito em relação ao dente humano com $R X$}

Utilizou-se filme radiográfico periapical da marca $\operatorname{Kodac}^{\circledR}$ e aparelho de raio-X da marca Funk ${ }^{\circledR}$ com ampola gradeada e cilindro orientador de feixe. Fez-se preparos cavitários em dentes humanos extraídos (molares, pré-molares e incisivos) para realização de capeamentos diretos e preparos cavitários para pulpotomias.

Preparou-se o Compósito e fez-se a inserção do mesmo nos dentes selecionados. Em seguida realizou-se tomadas radiográficas de acordo com os padrões da clínica odontológica. As radiografias foram obtidas com intervalos de tempo como descrito no ítem III.2.4.3. letra A. 


\section{IV. - RESULTADOS E DISCUSSÃO}

\section{IV.1. Caracterização das matérias-primas}

\section{IV.1.1. Colágeno Aniônico}

O tratamento com uma solução fortemente alcalina provoca a hidrólise de grupos carboxiamidas dos resíduos de Asn e Gln presentes na estrutura primária do tropocolágeno, segundo a reação mostrada na Figura 15. O grupo de Bioquímica e Biomateriais tem preparado este tipo de material em vários tempos de tratamento (12$144 \mathrm{~h}$ ) e o tempo de $24 \mathrm{~h}$ foi escolhido por ser um dos que apresentam a melhor resposta biológica (BET, 2000).

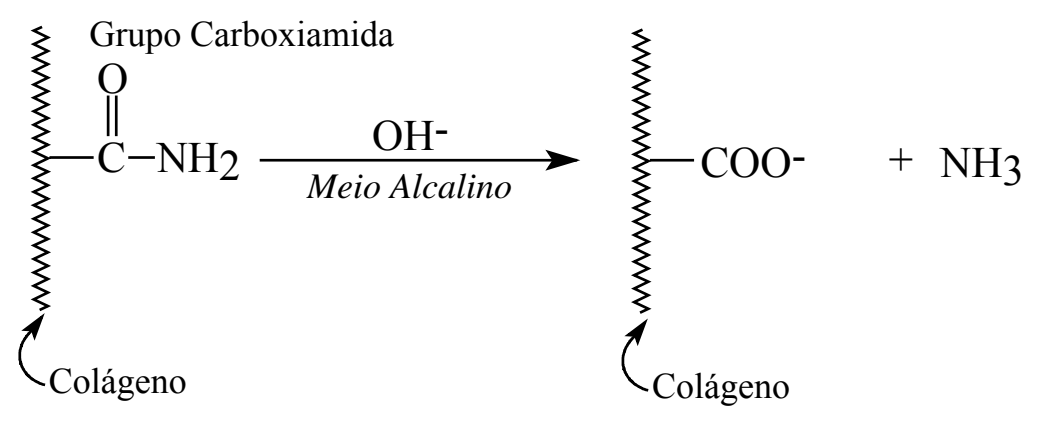

FIGURA 15. - Esquema representativo da hidrólise alcalina dos grupos carboxiamidas.

Como o colágeno já havia sido preparado e caracterizado pelo grupo de Bioquímica e Biomateriais do Instituto de Química de São Carlos SP, sabe-se que a concentração da preparação de Colágeno $24 \mathrm{~h}$ empregada neste trabalho foi anteriormente determinada por processos de liofilização e indiretamente pela determinação da Hypro após hidrólise ácida da proteína e foi na ordem de $1,11 \% \mathrm{~m} / \mathrm{m}$ por liofilização contra 1,01\% determinada por Hypro (STEGEMANN \& STALDER, 1967). Esta diferença pode ser explicada pelo fato de que materiais de colágeno quando liofilizados absorvem água rapidamente em valores de massa que atingem até $20 \%$ do seu peso, fato comprovado pela quantidade de água presente na preparação do Compósito (CPBHAC) onde o colágeno foi o diluente da formulação o que permitiu a inserção da massa obtida, nos moldes cilíndricos das amostras. 
Na realidade a liofilização das preparações de colágeno, servem para se obter uma estimativa de sua concentração, para a aplicação e outras metodologias analíticas. O grupo de bioquímica e biomateriais do IQSC analisou os pesos moleculares dos componentes protéicos presentes nos materiais preparados e a determinação foi por eletroforese e a solubilização à $\mathrm{pH} 3,5$ em géis de poliacrilamida/SDS a 10\%. Os resultados obtidos mostraram que o material preparado foi caracterizado pela presença de bandas correspondentes a proteínas com pesos moleculares de 98.000 e $95.000 \mathrm{Da}$, valores similares àqueles descritos para as cadeias $\alpha 1$ e $\alpha 2$, típicas do colágeno do tipo I (RAMACHANDRAN, 1967), material predominante na matéria prima empregada, ou seja, serosa porcina. Devido à ação desnaturante do lauril sulfato de sódio (SDS) não é possível garantir que o colágeno se encontre na forma de tripla hélice apesar dos resultados da análise por eletroforese ter mostrado no processo de preparação frações típicas. Tais propriedades puderam ser avaliadas por FTIR e análise térmica.

O espectro vibracional FTIR para a membrana de colágeno formatada em solução ácida pH 3,5 (Figura 16), mostra duas bandas em 1658 e $1552 \mathrm{~cm}^{-1}$, correspondentes a bandas da amida I e II, e devidas respectivamente a deformação axial da ligação $\mathrm{C}=\mathrm{O}$ e a deformação angular da ligação $\mathrm{N}-\mathrm{H}$. A região entre $600-800 \mathrm{~cm}^{-1}$, aparece na forma de uma banda larga de intensidade média. Entretanto, a integridade da estrutura da tripla hélice da estrutura colagênica pode ser mostrada pela relações de absorbâncias medidas a 1235 e $1450 \mathrm{~cm}^{-1}$, devidas à amida III e a ligação C-H do anel pirrolidínico. Enquanto a primeira é sensível à presença de estrutura secundária do colágeno a segunda independe da estrutura ordenada do tropocolágeno (SILVESTER et al., 1989). Para materiais formatados em solução ácida $\mathrm{pH} \mathrm{3,5,} \mathrm{a} \mathrm{integridade} \mathrm{da}$ estrutura secundária do tropocolágeno pode ser verificada quando o valor da relação $1235 / 1450 \mathrm{~cm}^{-1}$ for maior ou igual a unidade. Para o material preparado e utilizado neste trabalho, o valor encontrado para esta relação foi de 1,01, portanto, significativamente maior do que aquele que seria observado para estruturas desnaturadas, cujos valores estão por volta de 0,5 (SIVESTER et al., 1989). O espectro obtido foi similar àquele de preparações comerciais de colágeno, onde sob condições similares, o valor encontrado para esta relação foi de 0,99 . 


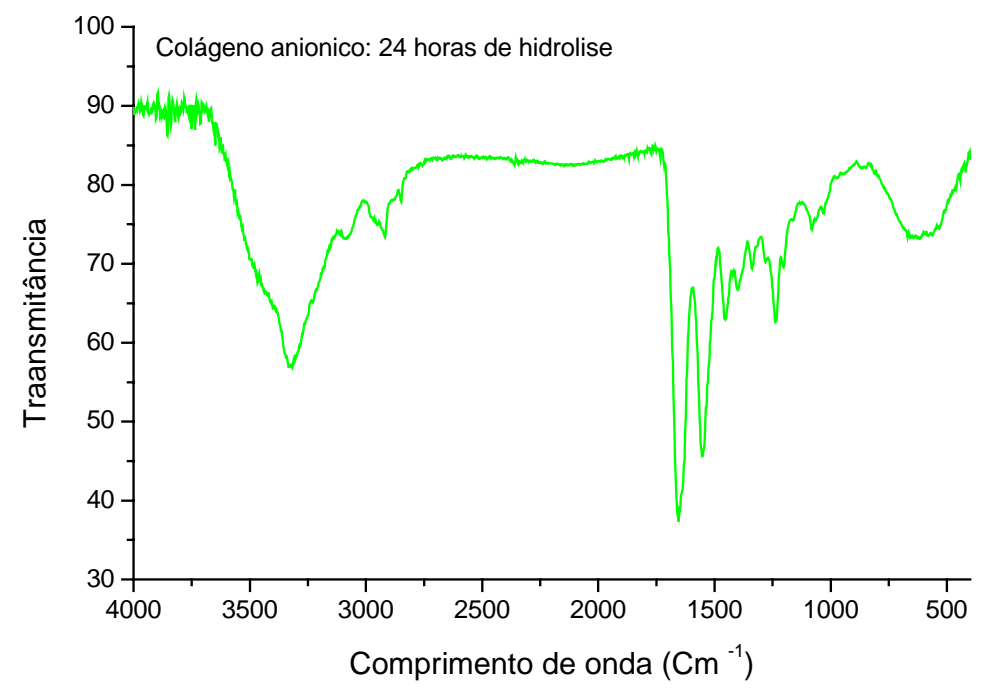

FIGURA 16. - Espectroscopia na região do infravermelho para o colágeno 24 horas.

Esses resultados, FTIR e eletroforese, juntamente com os de estabilidade térmica (Figura 17), mostram que o método de preparação do colágeno adotado pelo grupo de bioquímica, mostrou-se eficiente com valores de desnaturação para o colágeno comumente encontrado para o colágeno do tipo I (RAMACHANDRAN, 1967).

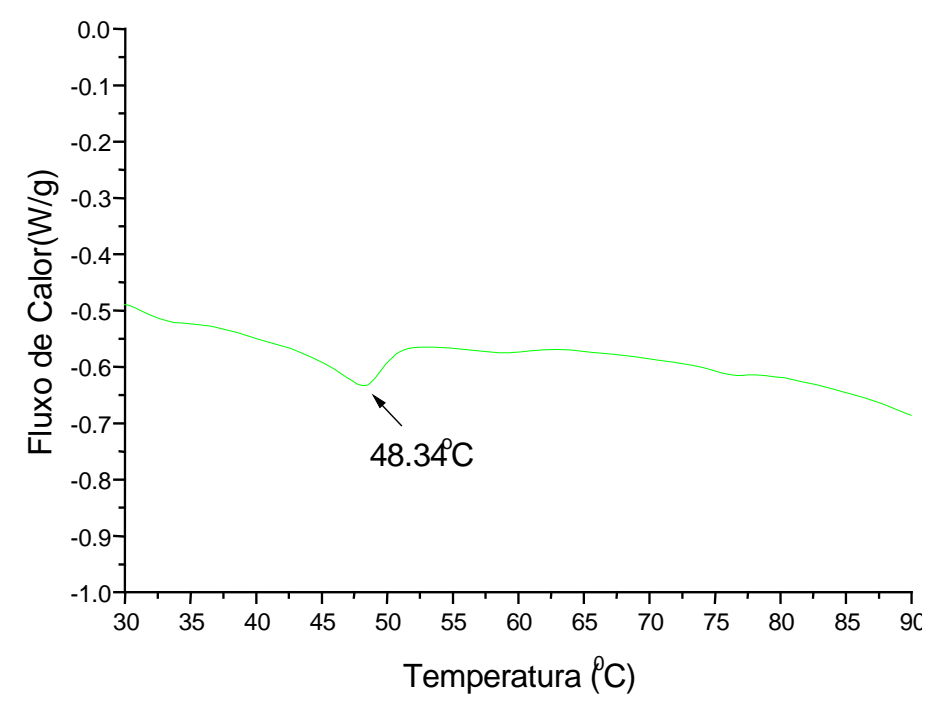

FIGURA 17. - Curva de Calorimetria Exploratória Diferencial obtida da amostra de Colágeno porcino (24 horas). 


\section{IV.1.2. - Cimento Portland Branco (CPB)}

O cimento Portland branco é composto com partículas hidrofílicas, cujos principais componentes são silicato tricálcico, aluminato tricálcico, óxido tricálcico e óxido de silicato, além de outros óxidos minerais. Este se diferencia do MTA, um agregado de Trióxido Mineral que já se encontra estabelecido no mercado, devido às qualidades comprovadas através de artigos e trabalhos científicos. Comparando o CPB com o MTA, podemos verificar a semelhança na composição química entre ambos, exceto a presença do bismuto (ESTRELA et al., (2000).

A existência de poucos trabalhos na literatura comprovando a semelhança de comportamento do cimento Portland branco com o MTA sobre o tecido conjuntivo pulpar, por exemplo, (WUCHERPFENNING \& GREEN, 1999, HOLLAND et al., 2001; MENEZES et al., 2003), que em seus resultados de pesquisa demonstraram um alto percentual de sucesso, com formação de ponte de tecido mineralizado e preservação do tecido pulpar, mostra a necessidade de se fazer estudos adicionais para a viabilidade do uso desse material alternativo ao MTA com associações de materiais, que é o nosso objetivo de obter o Compósito (CPBHAC).

O cimento Portland obtido comercialmente foi submetido ao processo de Calcinação a $500^{\circ} \mathrm{C}$ para garantir a eliminação de quaisquer resquícios de materiais orgânicos ficando apenas a parte mineral (Silicatos). A retirada do CPB do forno a $100^{\circ} \mathrm{C}$ foi para deixá-lo sem incorporação de umidade. Para manutenção foi estocado em dessecador até a sua utilização.

A analise térmica deste material nos mostrou uma quantidade de água em torno de $0,5 \%$ (Figura 18), o que aparentemente parece não afetar a preparação do compósito. 


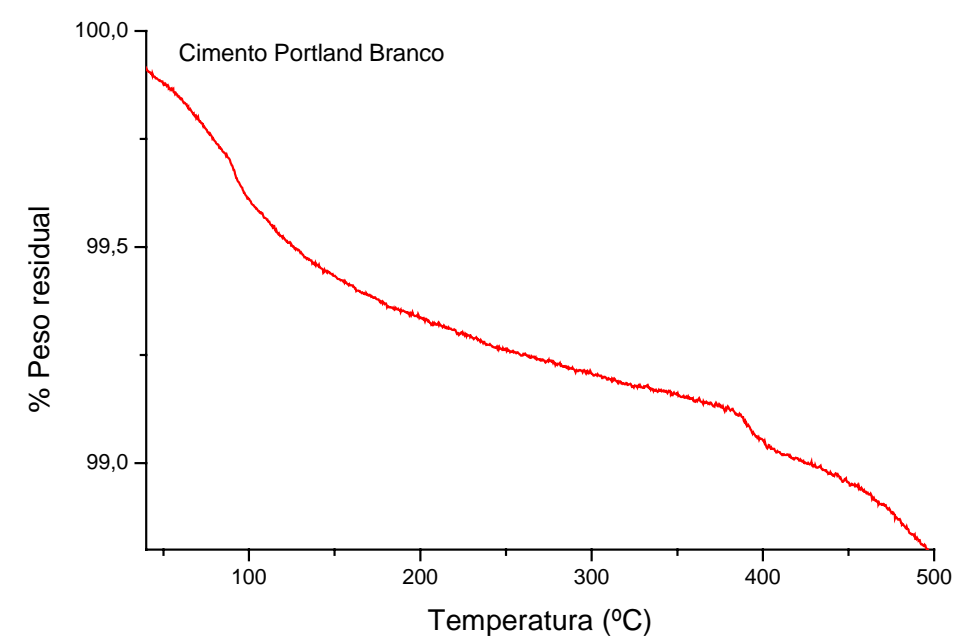

FIGURA 18. - Curva Termogravimétrica da amostra de Cimento Portland Branco, obtido comercialmente.

O espectro vibracional, na região do infravermelho (Figura 19), obtido para a amostra de CPB está mostrado na Figura 16. As principais bandas observadas são aquelas em torno de $3300 \mathrm{~cm}^{-1}$ de grupamentos $\mathrm{OH}$ devido á água, aquelas próximas de $1500 \mathrm{~cm}^{-1}$ devido a ligação dos grupos de sílica e em torno de $878 \mathrm{~cm}^{-1}$ devido a vibração de ligação P-O fora do plano.

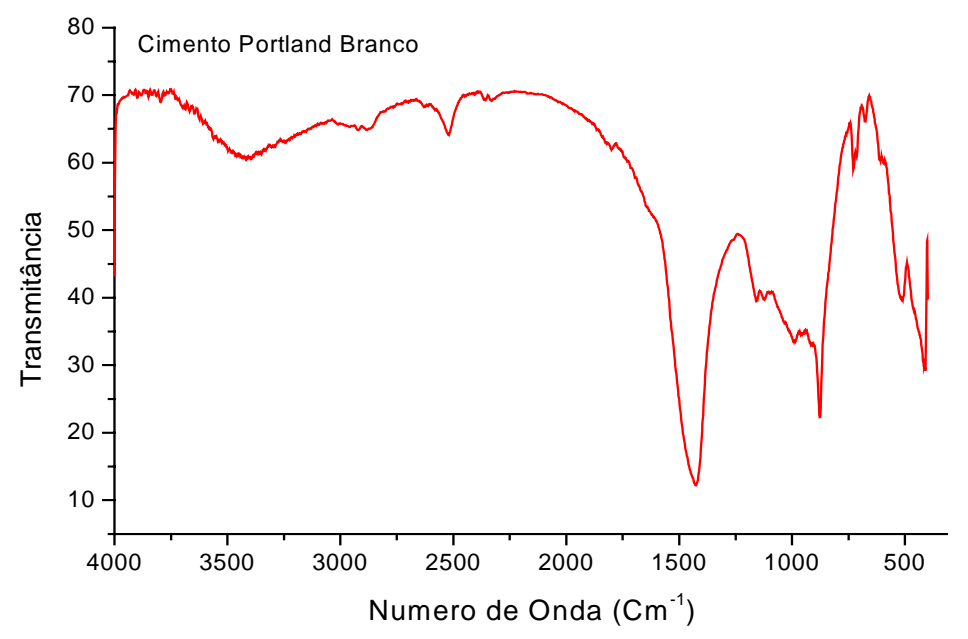

FIGURA 19. - Espectroscopia na região do infravermelho para o Cimento Portland Branco obtido comercialmente 


\section{IV.1.3. - Hidroxiapatita (HA)}

Embora não mostrado, a análise por DSC mostrou um pico endotérmico em $100^{\circ} \mathrm{C}$ de grande intensidade, que provavelmente refere-se à perda de água, o que foi também demonstrada por espectros na região do infravermelho (banda em $3435 \mathrm{~cm}^{-1}$, referente ao estiramento $\mathrm{OH})$ e também por termogravimentria ( $\approx 2 \%$ de água) - Figura 20. A Figura 20 também nos mostra uma transição entre 200 a $300^{\circ} \mathrm{C}$ o que pode ser uma pequena quantidade de $\mathrm{CO}_{3}{ }^{-}$incorporada durante a síntese (ŚLÓSARCZYK et al., 2005).

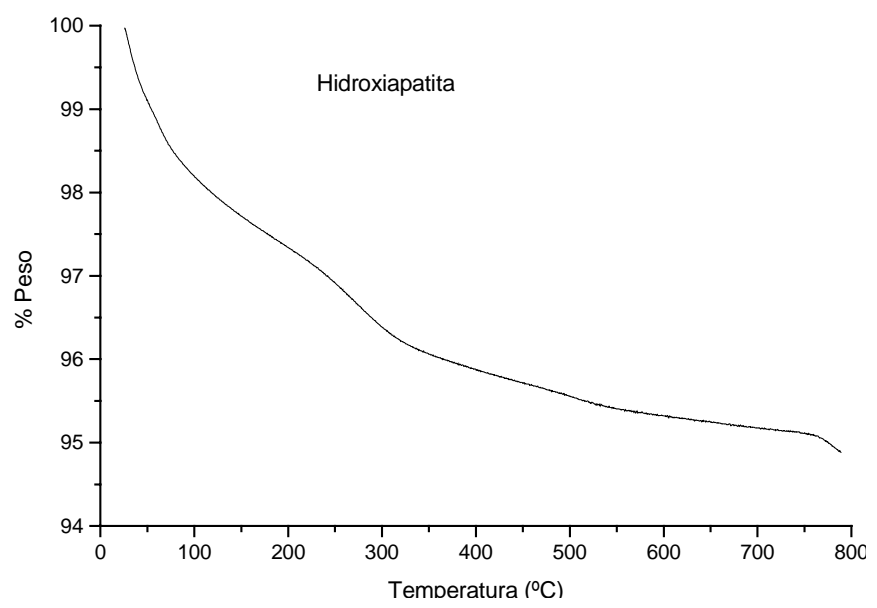

FIGURA 20. - Curva Termogravimétrica da amostra de Hidroxiapatita sintetizada.

De acordo BET (1995), a relação $\mathrm{Ca} / \mathrm{P}$ determinada foi de 1,53, diferente de 1,67 que é típico para a HA convencional (AOKI, 1991), considerando que a fórmula da hidroxiapatita é $\mathrm{Ca}_{10}\left(\mathrm{PO}_{4}\right)_{6}(\mathrm{OH})_{2}$, onde os valores percentuais de $\mathrm{Ca}$ e $\mathrm{P}$ deveriam ser respectivamente de 39,9 e 18,5\%. Estes resultados nos mostram uma pequena deficiência em cálcio, semelhante, porém, à hidroxiapatita encontrada em ossos em seu estágio inicial. Outra característica importante é que a análise por EDX feita por BET em tese de mestrado mostrou a presença de apenas três picos, dois referentes ao elemento cálcio e um referente ao elemento fósforo.

Embora os resultados acima pudessem sugerir a uma estrutura do tipo fosfato tricálcio cuja relação Ca/P é de 1,50 (DRISSENS et al., 1994), os resultados de FTIR (Figura 37) mostraram que o produto é efetivamente a hidroxiapatita. 


\section{IV.2. Caracterização das amostras complemen- tares}

O objetivo principal deste trabalho foi a obtenção de um compósito de colágeno/hidroxiapatita juntamente com cimento Portland branco. No entanto, antes de descrever os resultados obtidos para este material, convém analisar isoladamente alguns dos seus componentes antes da mistura final. Por isso, descrevemos primeiramente as análises das amostras complementares que são aquelas de cimento Portland branco com água e de cimento Portland branco com hidroxiapatita e água.

\section{IV.2.1. Microscopia Eletrônica de Varredura (MEV) do grupo 1 (Cimento Portland Branco + Água) CPBW)}

As fotomicrografias de MEV (Figuras 21 a 23) mostram pequenos grãos de cimento e uma maior quantidade de agregação devido a presença de água. Isto acontece pelo fato de ser composto por partículas pequenas.

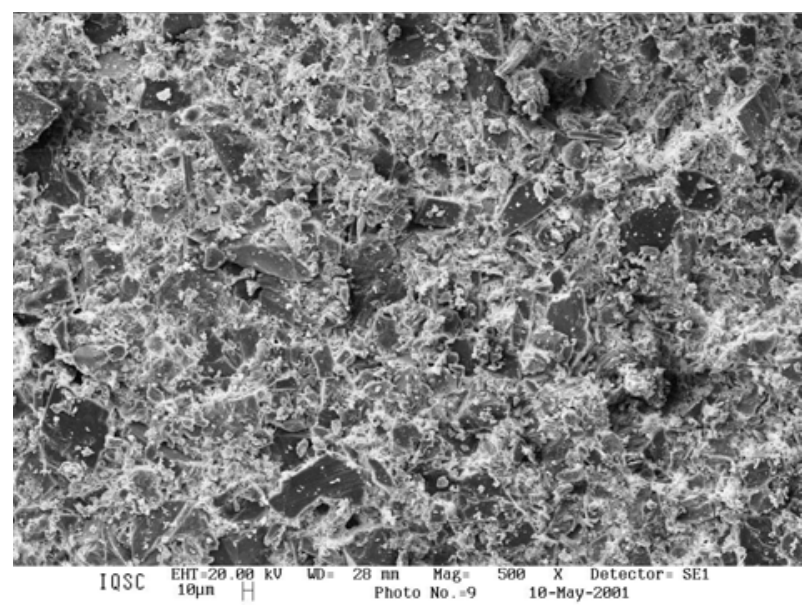

FIGURA 21. - Micrografia eletrônica de varredura da amostra (Cimento Portland Branco + Água) em aumento de 500x 


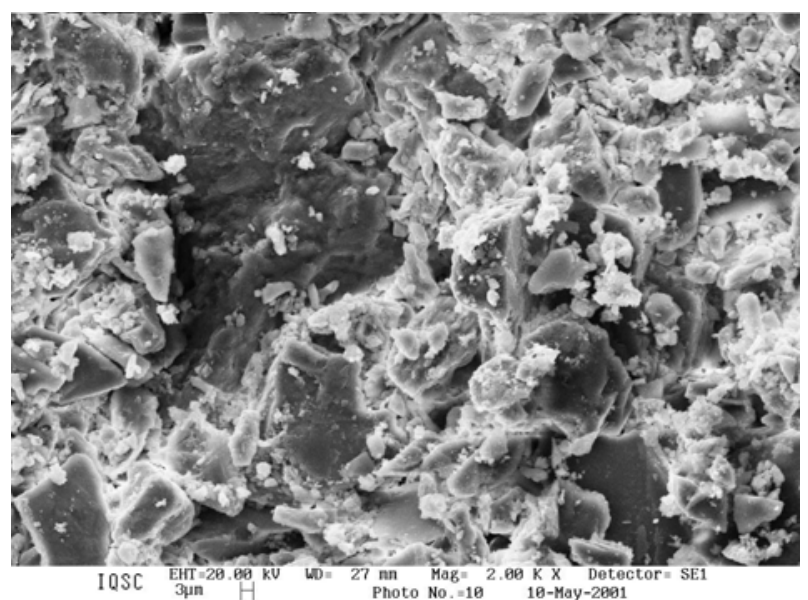

FIGURA 22. - Micrografia eletrônica de varredura da amostra (Cimento Portland Branco + Água) em aumento de 2000x

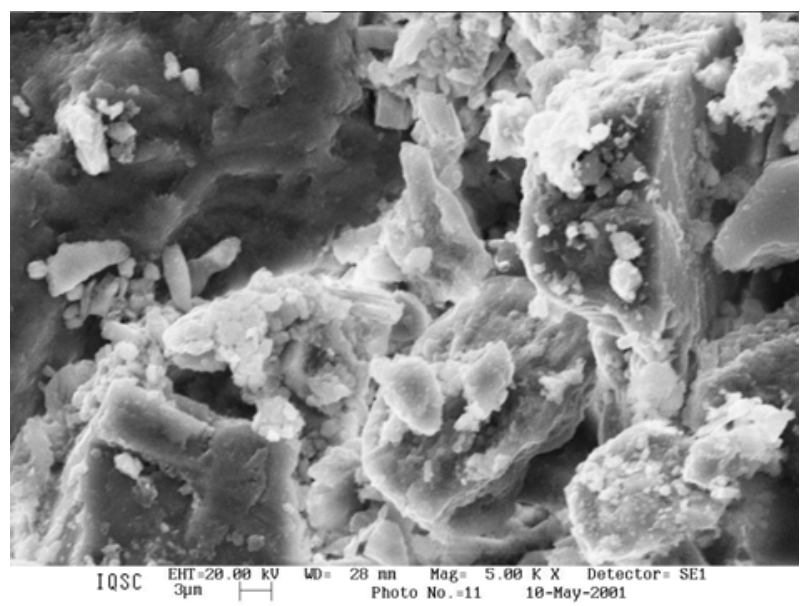

FIGURA 23. -Micrografia eletrônica de varredura da amostra (Cimento Portland Branco + Água) em aumento de 5000x

\section{IV.2.1.1. - Espectroscopia de Dispersão de Energia de Raios-X (EDX) do grupo 1 (Cimento Portland Branco + Água) (CPBW)}

O aspecto heterogêneo observado pelas micrografias de MEV pôde ser comprovado por análises de EDX (Figuras 24 a 28). Estes espectros mostram picos referentes ao fósforo e cálcio além de outros elementos do cimento. 

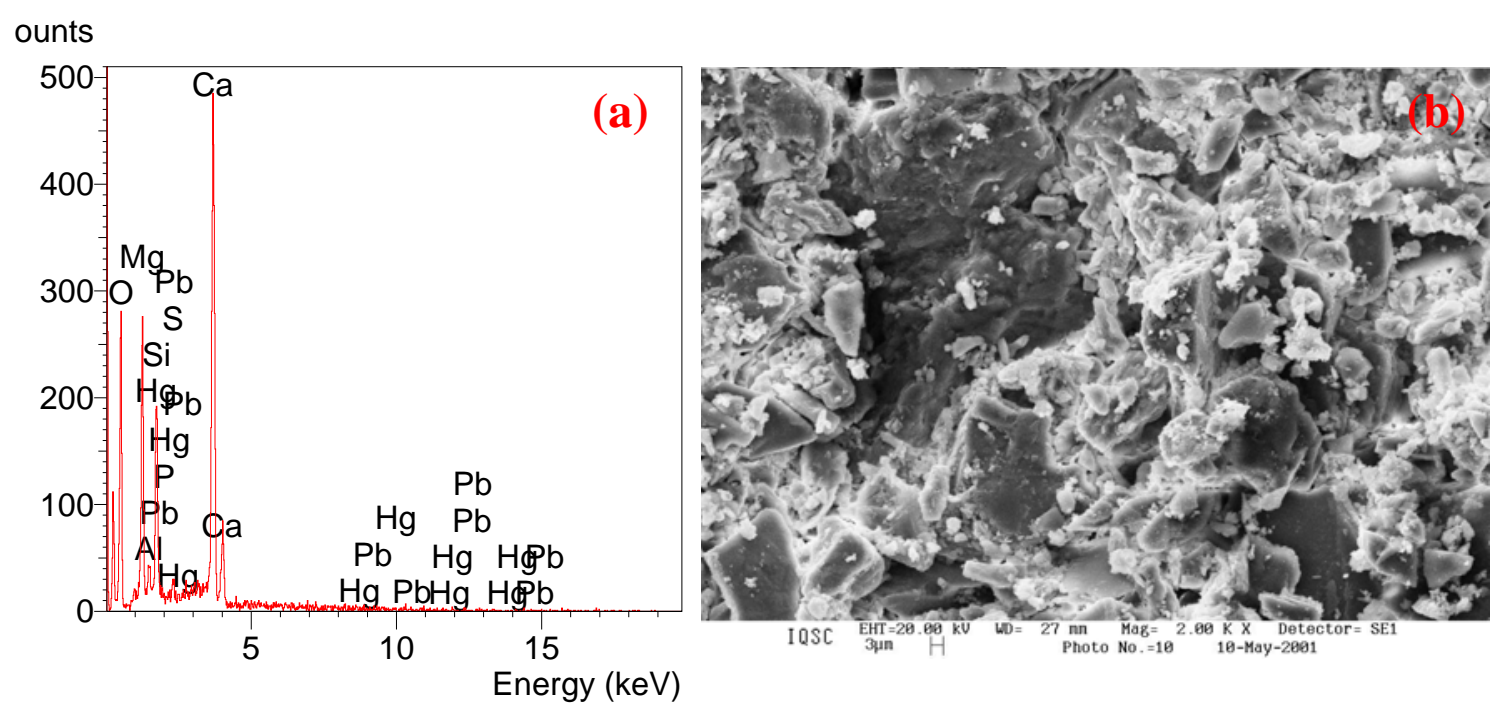

FIGURA 24. - (a) Curva de Espectroscopia de Dispersão de Energia de Raios-X e (b) Micrografia eletrônica de varredura da amostra (Cimento Portland Branco + Água) em aumento de 2000x.
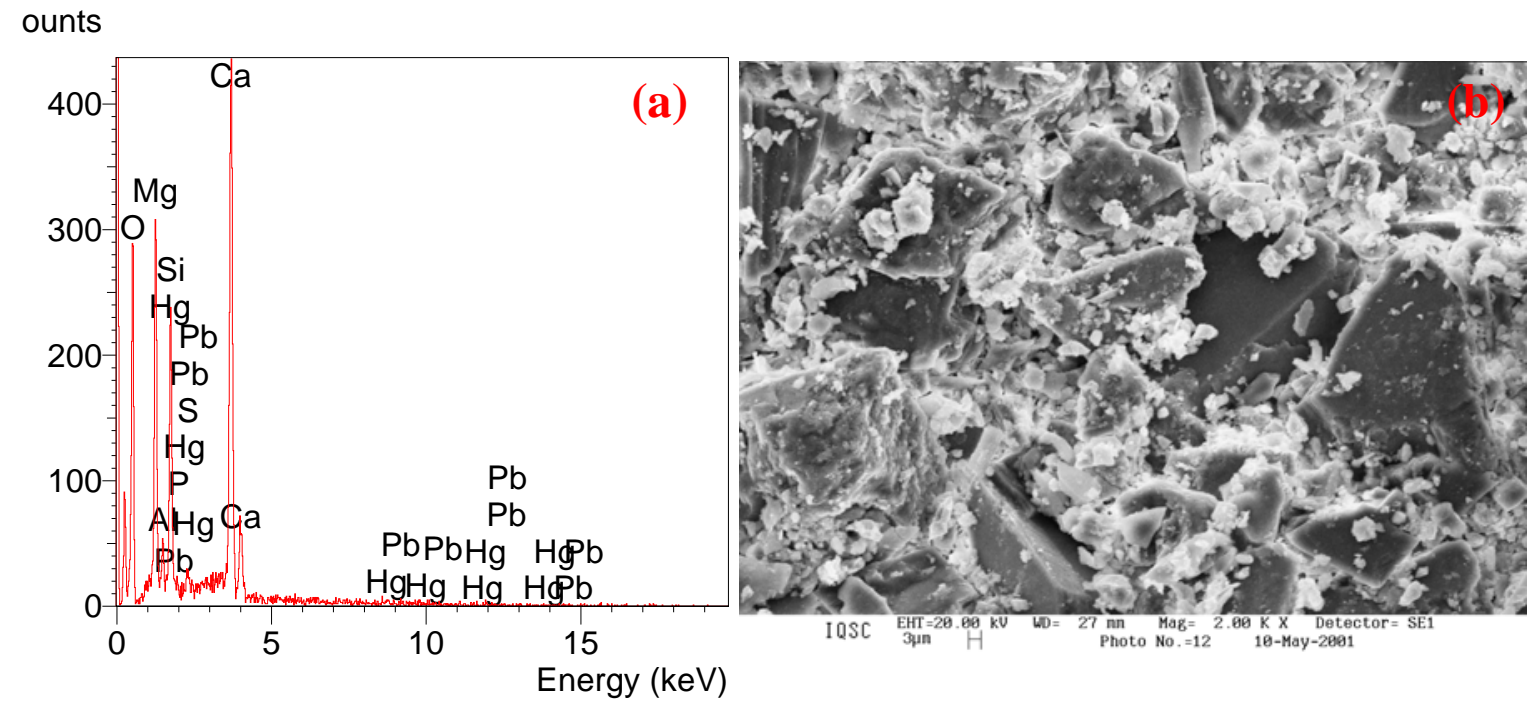

FIGURA 25. - (a) Curva de Espectroscopia de Dispersão de Energia de Raios-X e (b) Micrografia eletrônica de varredura da amostra (Cimento Portland Branco + Água) em aumento de 2000x 


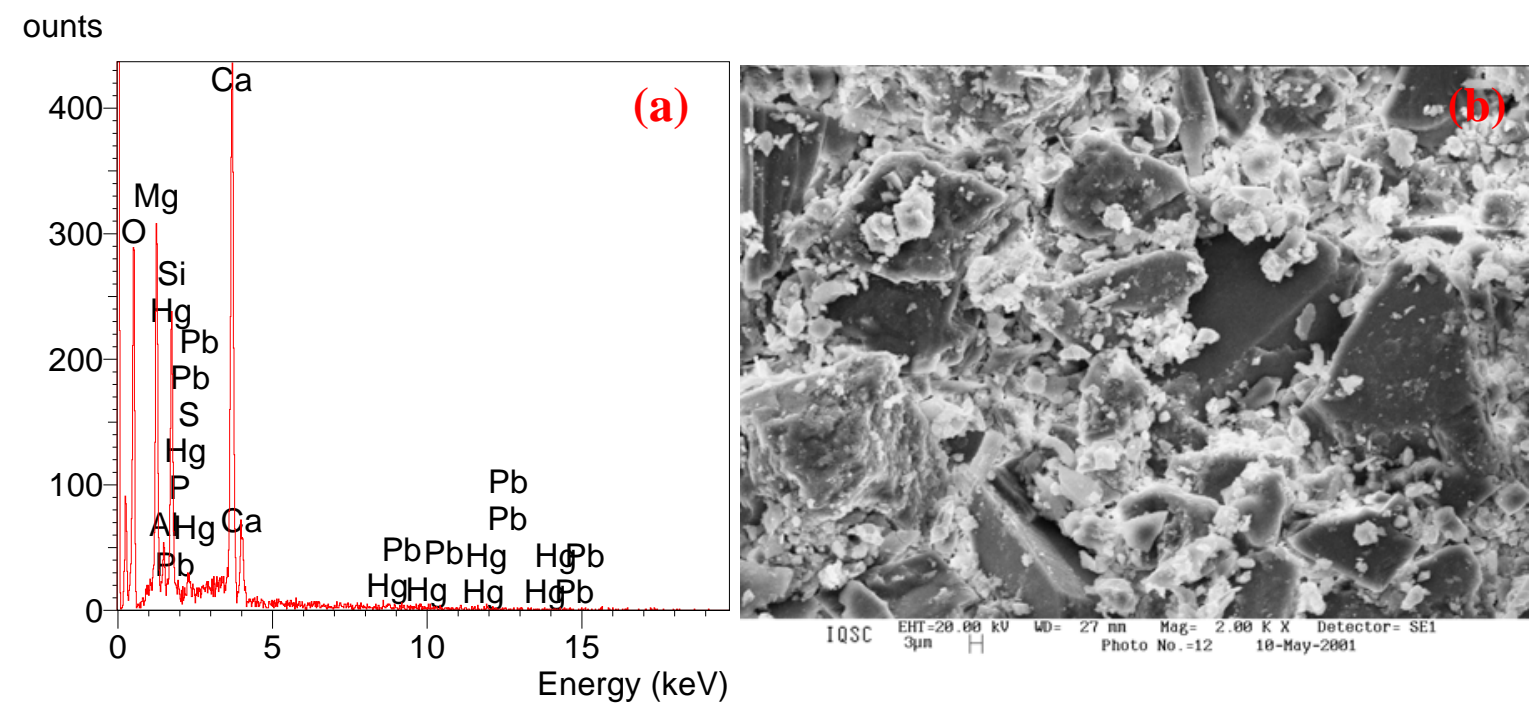

FIGURA 26. - (a) Curva de Espectroscopia de Dispersão de Energia de Raios-X e (b) Micrografia eletrônica de varredura da amostra (Cimento Portland Branco + Água) em aumento de 2000x

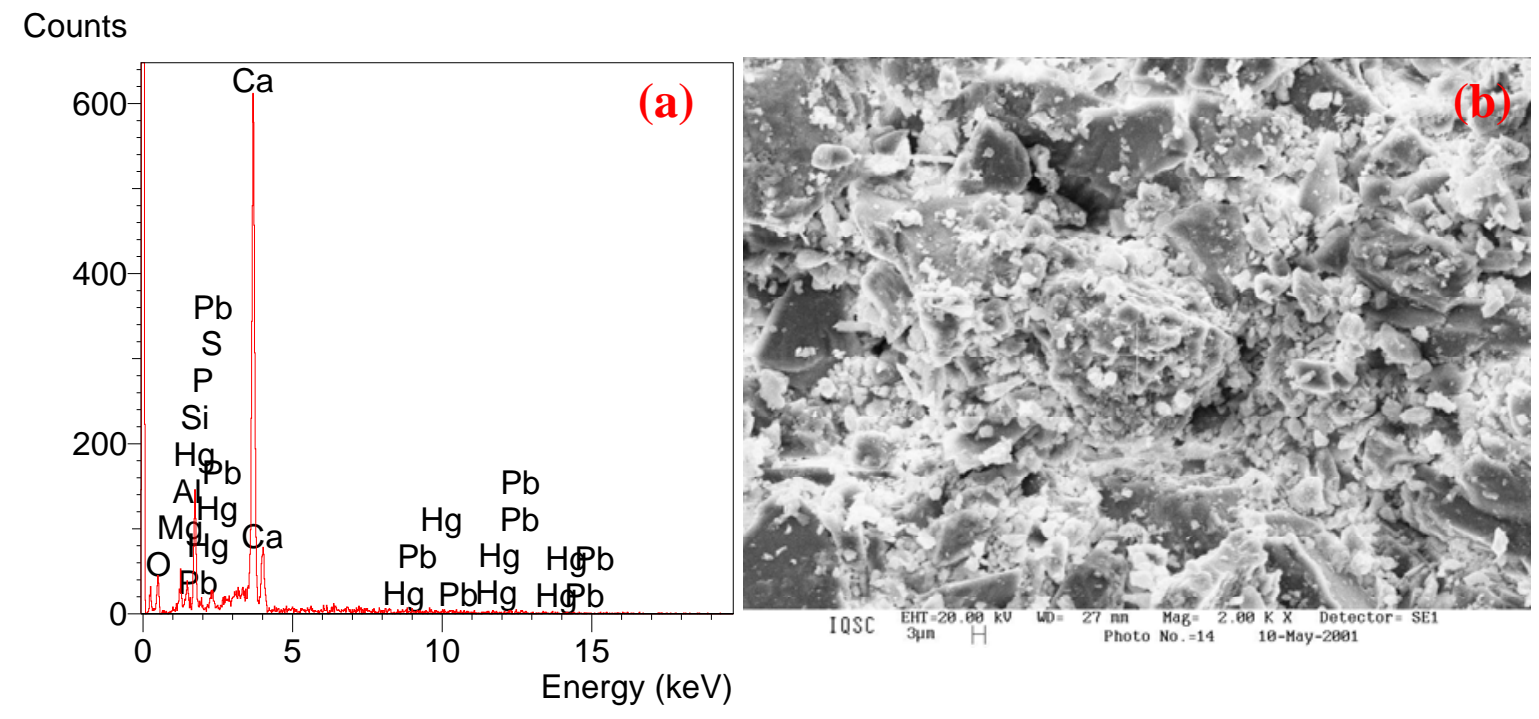

FIGURA 27. - (a) Curva de Espectroscopia de Dispersão de Energia de Raios-X e (b) Micrografia eletrônica de varredura da amostra (Cimento Portland Branco + Água) em aumento de $2000 x$ 

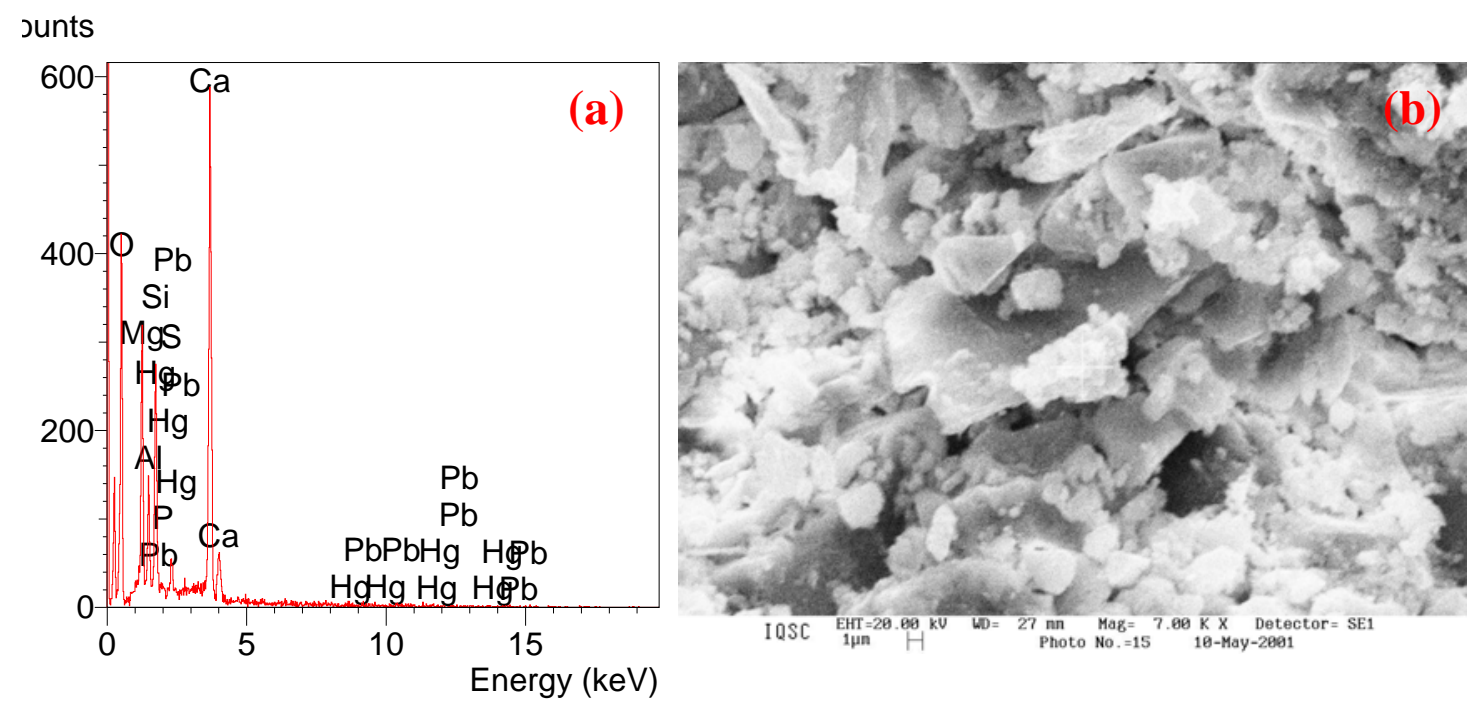

FIGURA 28. - (a) Curva de Espectroscopia de Dispersão de Energia de Raios-X e (b) Micrografia eletrônica de varredura da amostra (Cimento Portland Branco + Água) em aumento de 7000x

\section{IV.2.2. Microscopia Eletrônica de Varredura (MEV) do grupo 2 (Cimento Portland Branco + Hidroxiapatita + Água) (CPBHAW)}

As Figuras 29 a 32 correspondem a micrografias do compósito cimento Portland:HA com aumentos entre 500 a 5000x. Podem ser observados além de um aspecto mais homogêneo quando comparados com cimento Portland:água (Figuras 21 a 23), grãos de HA com variação de forma e tamanho, devido à síntese ser realizada em via úmida, o que faz com que ocorra agregação do precipitado. Isto acontece pelo fato de ser composto por partículas pequenas. Desta forma, estes resultados sugerem que materiais com aspecto mais homogêneo talvez pudessem ser obtidos pela preparação inicial do compósito cimento Portland:HA, seguido de moagem e tamização. 


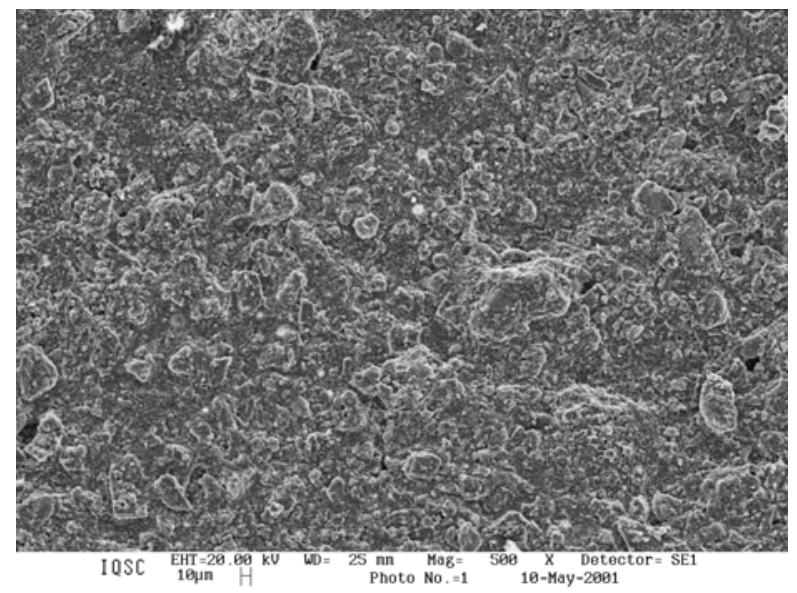

FIGURA 29. - Micrografia eletrônica de varredura da amostra (Cimento Portland Branco + Hidroxiapatita + Água) em aumento de 500x

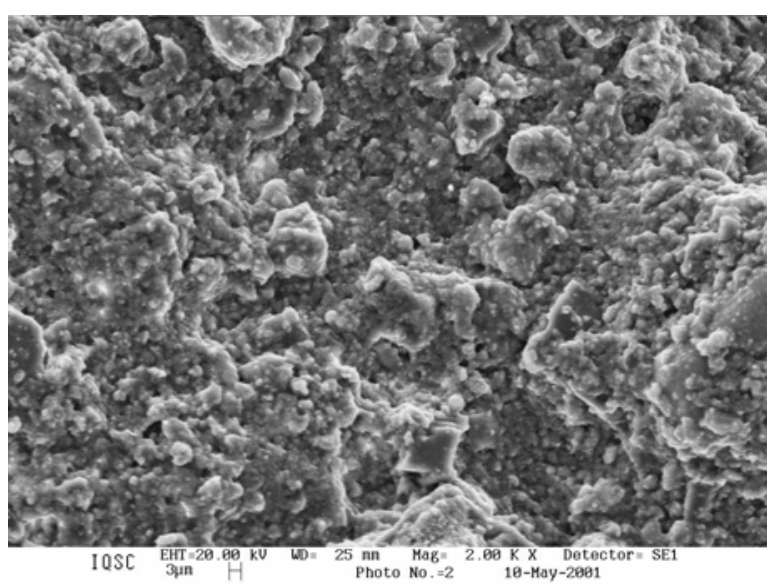

FIGURA 30. - Micrografia eletrônica de varredura da amostra (Cimento Portland Branco + Hidroxiapatita + Água) em aumento 2000x

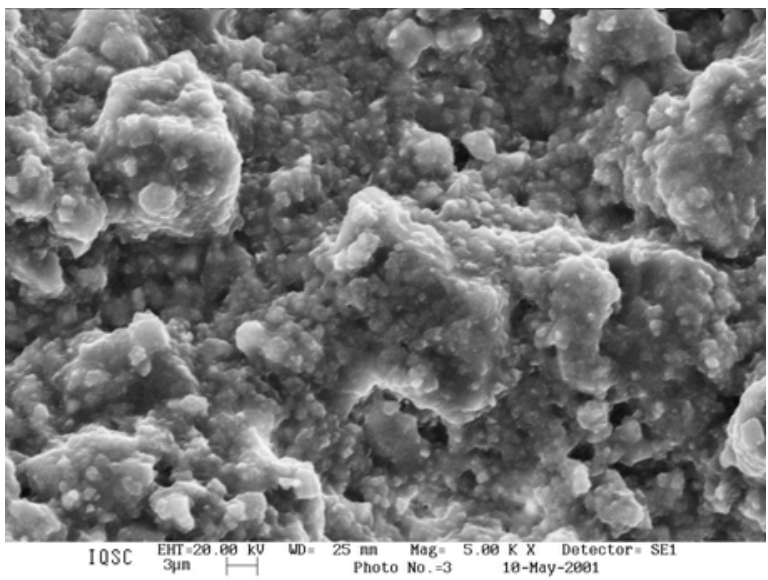

FIGURA 31. - Micrografia eletrônica de varredura da amostra (Cimento Portland Branco + Hidroxiapatita + Água) em aumento de 5000x 


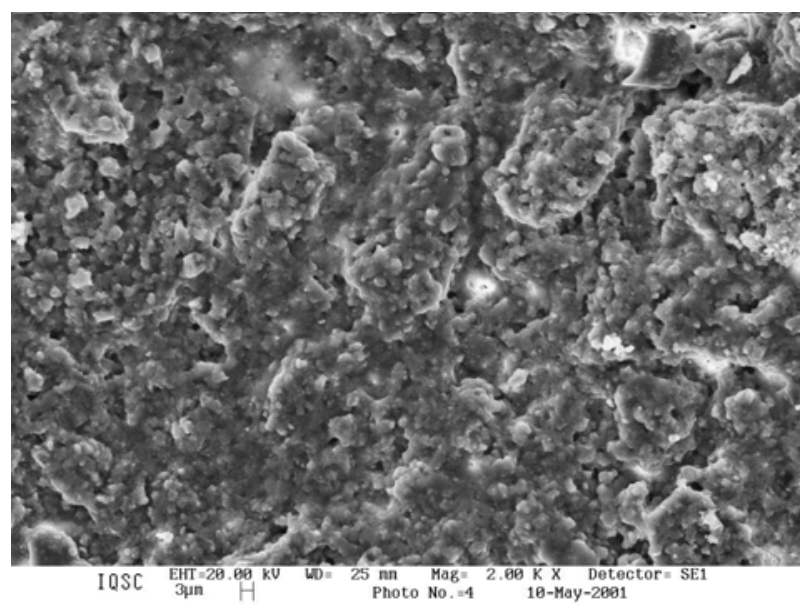

FIGURA 32. - Micrografia eletrônica de varredura da amostra (Cimento Portland Branco + Hidroxiapatita + Água) em aumento de 2000x

\section{IV.2.2.1. - Espectroscopia de Dispersão de Energia de Raios-X (EDX) do grupo 2 (Cimento Portland Branco + Hidroxiapatita + Água) (CPBHAW)}

O aspecto homogêneo observado pelas micrografias de MEV pôde ser comprovado por análises de EDX (Figuras 33a e 34a), com redução da quantidade de metais pesados, e um aumento na quantidade de $\mathrm{Ca}$ e $\mathrm{P}$ devido a adição de hidroxiapatita. Deve-se destacar que os picos referentes ao $\mathrm{Ca}$ e $\mathrm{P}$ são devidos à excitação de um elétron da camada $\mathrm{K}$ do fósforo e da excitação de dois elétrons da camada $\mathrm{K}$ do cálcio.
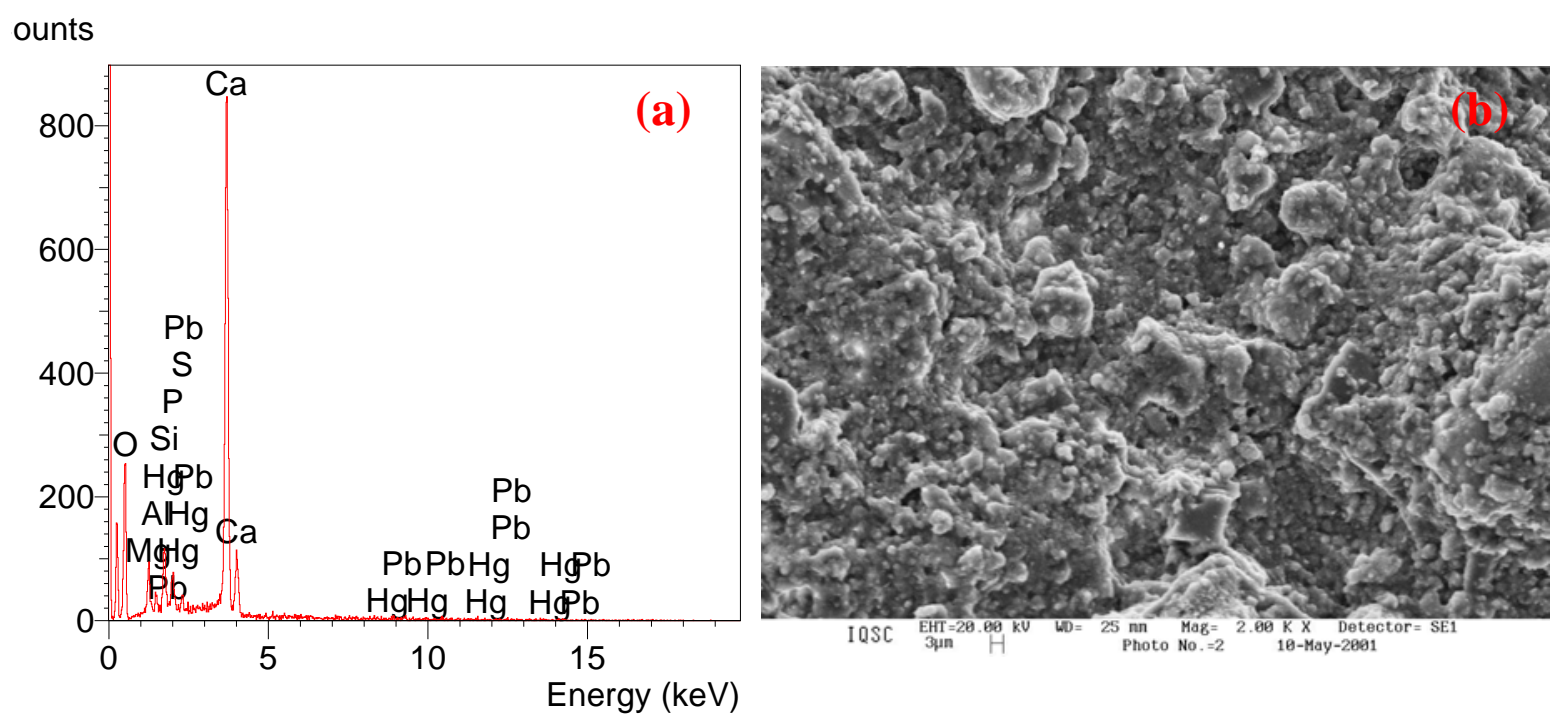

FIGURA 33. - (a) Curva de Espectroscopia de Dispersão de Energia de Raios-X e (b) Micrografia eletrônica de varredura da amostra (Cimento Portland Branco + Hidroxiapatita + Água) em aumento de 2000x 

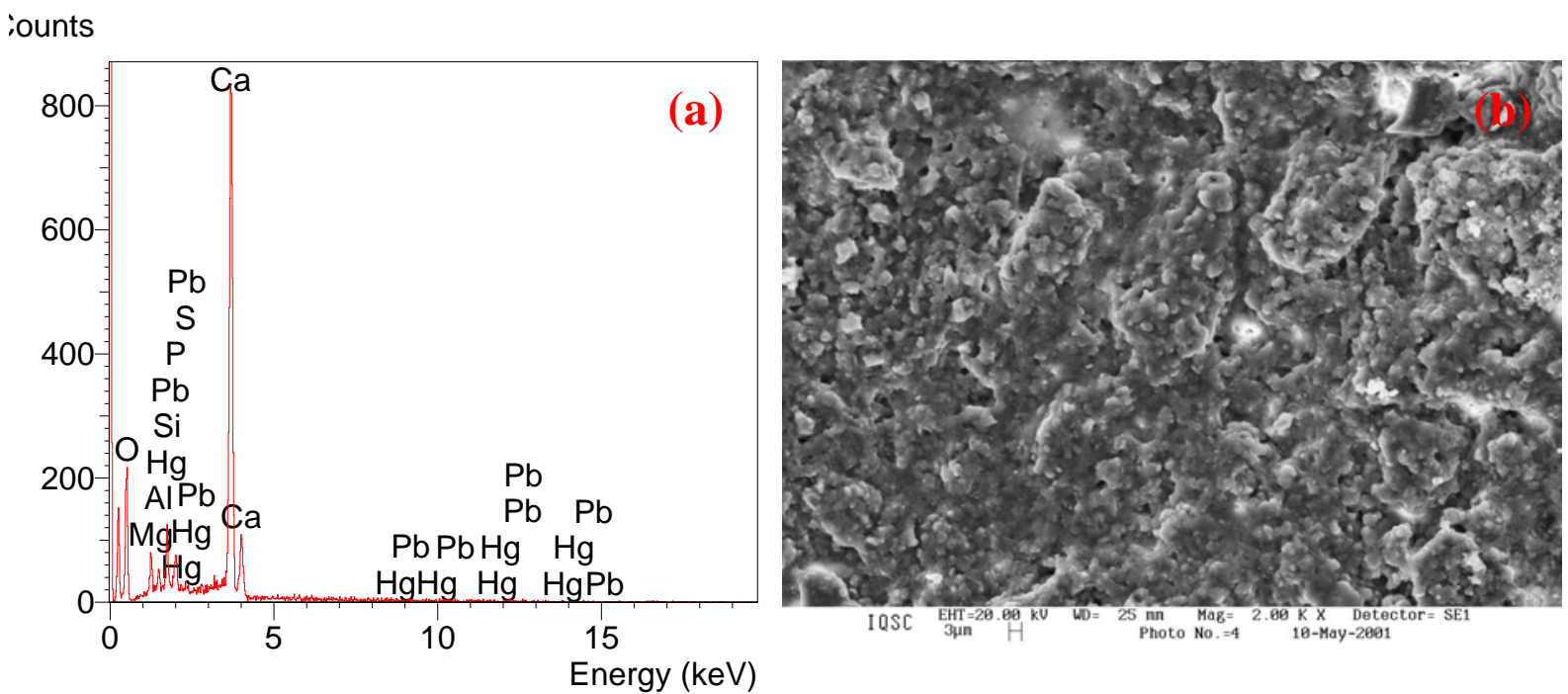

FIGURA 34. - (a) Curva de Espectroscopia de Dispersão de Energia de Raios-X e (b) Micrografia eletrônica de varredura da amostra (Cimento Portland Branco + Hidroxiapatita + Água) em aumento de 2000x

\section{IV.3. - Caracterização do Compósito de Colágeno com Silicato e Hidroxiapatita}

\section{IV.3.1. - Grupo 3 (Cimento Portland Branco + Hidroxiapatita + Colágeno) (CPBHAC)}

O aspecto macroscópico do compósito mostrou que logo após a preparação o aspecto foi de uma pasta com perda de umidade devido à presença do Colágeno na mistura. Sua coloração variou de branco a levemente amarelada com o passar das horas.

Pode-se observar que a medida em que foram adicionados os componentes para obtenção deste compósito, uma diminuição no "setting time” pode ser observada. Do instante inicial até trinta minutos a mistura foi perdendo o aspecto brilhante e assumindo uma característica fosca e endurecida.

Essas características, observadas por inspeção visual, aparentaram homogeneidade em todos os cilindros a partir dos moldes obtidos no Laboratório.

As primeiras amostras do Compósito foram acondicionadas em sacos plásticos e armazenadas em dessecador. Em novas inspeções feitas durante dois anos, as amostras demonstraram estabilidade quanto à coloração, opacidade e forma observada inicialmente. 
As medidas de $\mathrm{pH}$, desde o início do preparo do Compósito(CPBHAC) no tempo $(\mathrm{t}=0)$ mostrou-se altamente alcalino (em torno de 12) que é um resultado importante pois este $\mathrm{pH}$ é essencial para a ativação da fosfatase alcalina, ocorrendo com isso a inibição do sistema enzimático de reabsorção.Demonstra que ele torna o meio inóspito para o crescimento de bactérias, mantendo seu potencial antibacteriano por longo período e ainda a propriedade de ser hemostático.

A análise térmica (TG e DSC) do compósito mostrou uma transição em torno de $47,4^{\circ} \mathrm{C}$ (Figura 35 ) sugerindo que a estrutura da tripla hélice do colágeno foi preservada na preparação do compósito. Valores de TG do compósito e dos diferentes materiais presentes nele obtidos da Figura 36 e apresentados na Tabela 3, mostram uma quantidade de material residual em torno de 1,4\% para com colágeno, 94,8\% para a hidroxiapatita e $77,6 \%$ para o compósito que possivelmente está associado a quantidade de carbonato tanto na HA como no compósito.

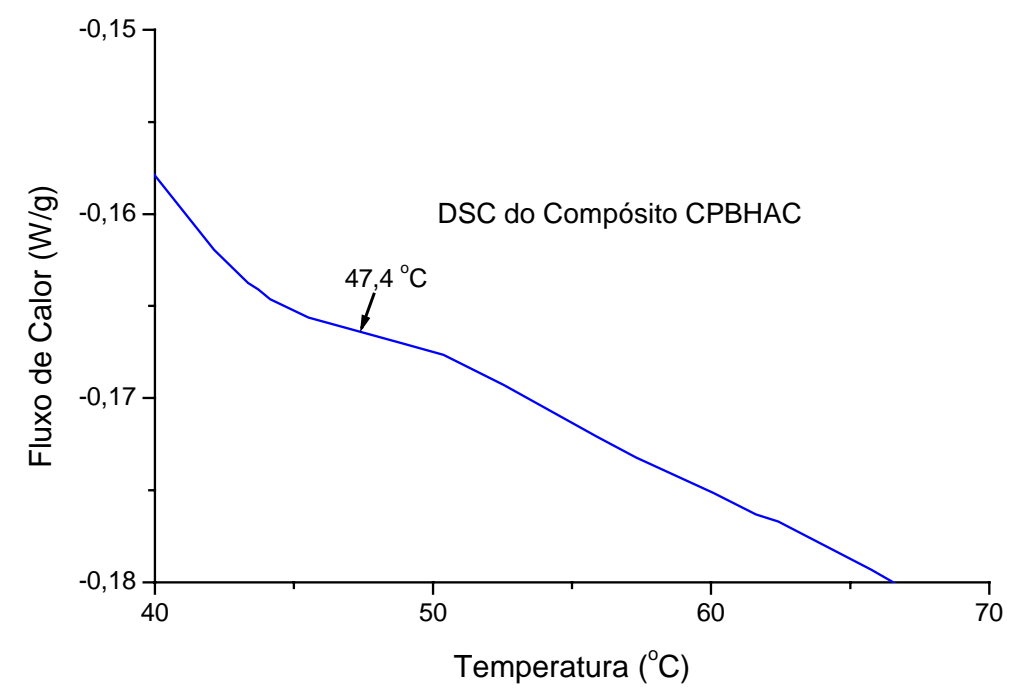

FIGURA 35. - Curva de Calorimetria Exploratória Diferencial da amostra do Compósito (Cimento Portland Branco + Hidroxiapatita + Colágeno). 


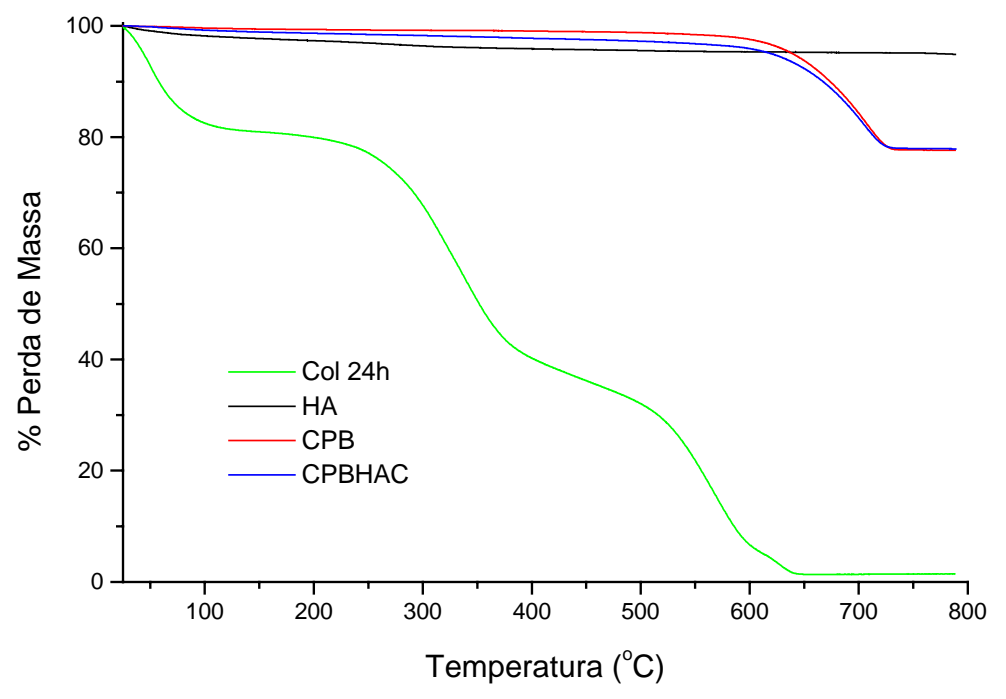

FIGURA 36. - Curvas Termogravimétricas das matérias-primas e do Compósito (Cimento Portland Branco + Hidroxiapatita + Colágeno).

TABELA 3. - Perdas de massa das preparações obtidas das respectivas curvas termogravimétricas

\begin{tabular}{|c|c|c|c|c|}
\hline \multirow{3}{*}{ Material } & \multicolumn{3}{|c|}{$\%$ peso } & \multirow{3}{*}{$\begin{array}{c}\text { Resíduo (\%) } \\
\mathrm{T}>800^{\circ} \mathrm{C}\end{array}$} \\
\hline & \multicolumn{3}{|c|}{ Temperatura $\left({ }^{\circ} \mathrm{C}\right)$} & \\
\hline & $20-200$ & $200-500$ & $500-800$ & \\
\hline Colágeno & 19,9 & 47,8 & 30,6 & 1,4 \\
\hline HÁ & 0,6 & 1,9 & 0,7 & 94,8 \\
\hline $\mathrm{CPB}$ & 0,7 & 0,5 & 21,2 & 77,6 \\
\hline СРВНАС & 1,4 & 1,4 & 19,3 & 77,9 \\
\hline
\end{tabular}

A presença de colágeno também pode ser comprovada pela espectroscopia na região do infravermelho (Figura 37) que nos forneceu uma razão das absorbâncias das bandas $\mathrm{A}_{1235} / \mathrm{A}_{1450}$ próximas de 1,0. Apesar das bandas de colágeno estarem menos evidentes em relação às bandas da hidroxiapatita, (esta razão pode ser medida na figura correspondente). Estes resultados (FTIR, DSC), indicam que o processo de incorporação de colágeno no compósito foi eficiente, pois estruturas desnaturadas apresentam valores da razão das absorbâncias próximos de 0,5 (GORDON et al., 1974).

Os espectros na região do infravermelho (Figura 37), mostram também a diminuição das intensidades das bandas de absorção características de íons fosfatos $\left(\mathrm{PO}_{4}{ }^{3-}\right)$ em 570, 962 e $1050 \mathrm{~cm}^{-1}$; uma banda larga e fraca em $3417 \mathrm{~cm}^{-1}$ e uma estreita 
em cerca de $3569 \mathrm{~cm}^{-1}$, característica de moléculas de água estruturais ou adsorvidas e aos íons $\mathrm{OH}^{-}$respectivamente; uma banda em $870 \mathrm{~cm}^{-1}$ referente a ligação $\mathrm{P}-\mathrm{OH}$. Na análise do Compósito (CPBHAC), pode ser observada pela diminuição da intensidade das bandas de amida I e amida III do colágeno. Bandas das vibrações do grupo fosfato e água presentes também na HA e CPB podem ser observadas em torno de $1000 \mathrm{~cm}^{-1} \mathrm{e}$ $3300 \mathrm{~cm}^{-1}$, respectivamente.

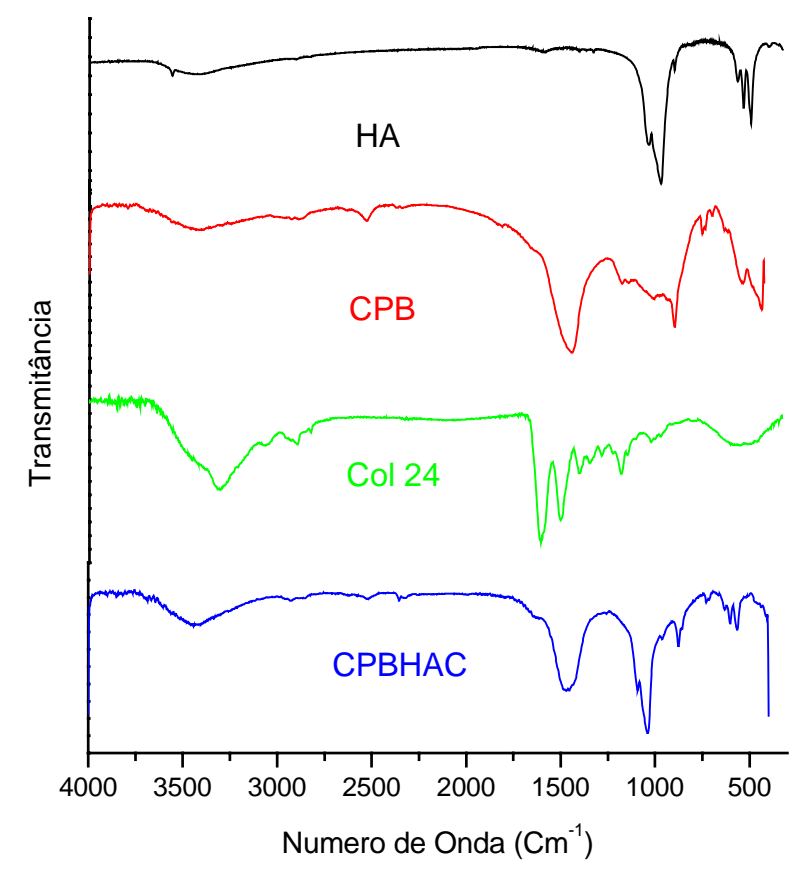

FIGURA 37. - Espectros de infravermelho obtidos para:- Hidroxiapatita, - Cimento Portland Branco, - Colágeno 24horas, - Compósito(Cimento Portland Branco + Hidroxiapatita + Colágeno)

\section{IV.3.2. - Microscopia Eletrônica de Varredura (MEV) do grupo 3 (Cimento Portland Branco + Hidroxiapatita + Colágeno) (CPBHAC)}

As análises das micrografias obtidas por MEV para as amostras do Compósito ( $C P B H A C$ - Figuras 38 a 41), foram realizadas com o objetivo de se verificar as estruturas das partículas inorgânicas presentes no CPB e na HA, assim como o tamanho médio das mesmas e as suas interações com o colágeno para avaliação da homogeneidade do material como pode ser observado nas fotos a seguir com aumentos de 300 a 2.000x. O aspecto das micrografias não difere significativamente daquelas do cimento Portland nativo (Figuras 21 a 28) sendo mesmo difícil observar filamentos da 
matriz de colágeno na micrografia. A Figura 41 parece indicar a presença de colágeno (setas amarelas) onde pode ser observada uma espécie de material filamentoso na superfície do material. Embora a presença de colágeno não pudesse ser evidenciada de modo claro nas micrografias de $\mathrm{MEV}$, sua presença ficou demonstrada pela técnica de DSC (Figura 35).

A Figura 38 mostra grãos de HA que embora não sejam uniformes, devido a síntese ser realizada em via úmida, estes estão agregrados às fibras de colágeno e esta agregação nos forneceu um compósito com consistência de pasta, com partículas de HA recobertas com estruturas filamentares.

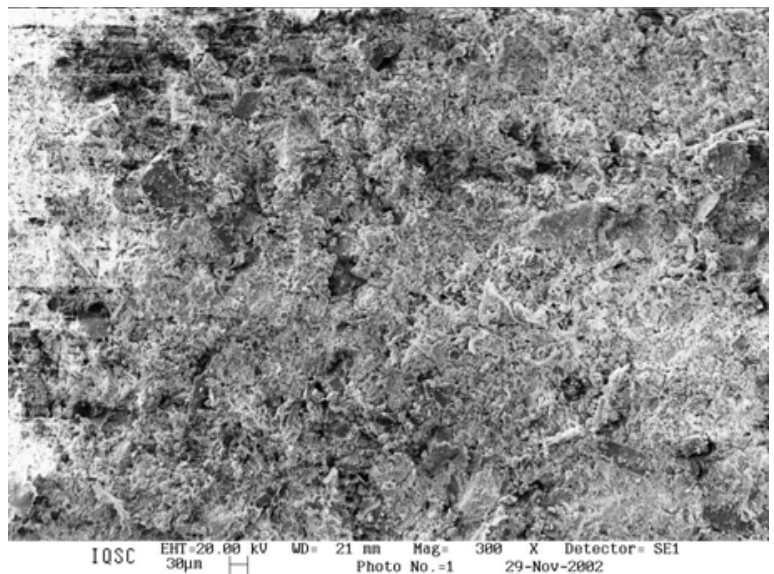

FIGURA 38. - Micrografia eletrônica de varredura da amostra do Compósito (Cimento Portland Branco + Hidroxiapatita + Colágeno 24h) em aumento de $300 \mathrm{x}$

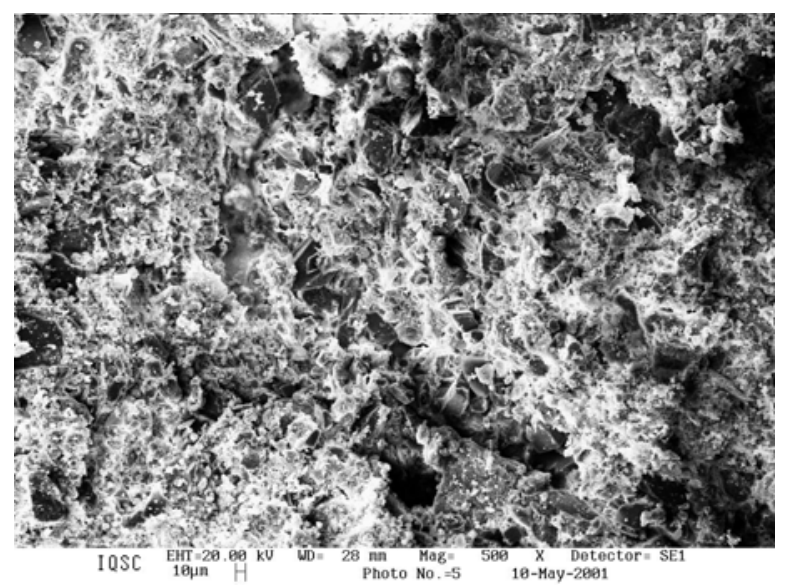

FIGURA 39. - Micrografia eletrônica de varredura da amostra do Compósito (Cimento Portland Branco + Hidroxiapatita + Colágeno 24h) em aumento de 500x 


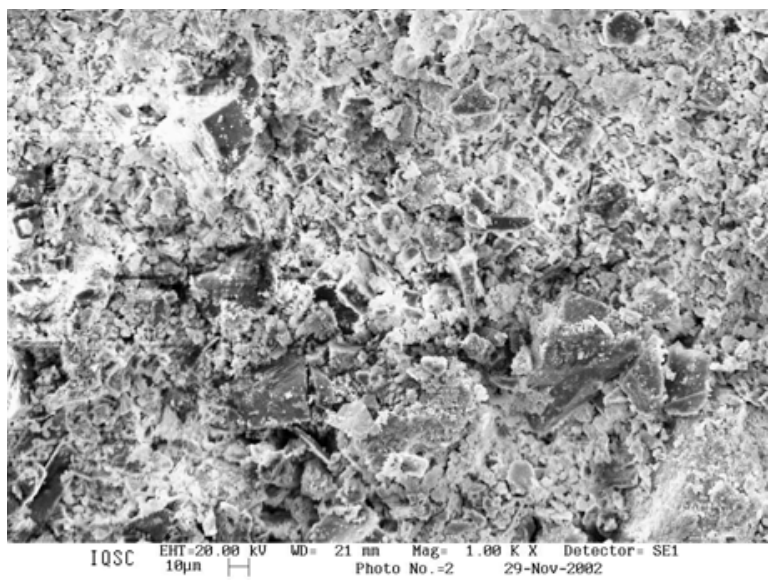

FIGURA 40. - Micrografia eletrônica de varredura da amostra do Compósito (Cimento Portland Branco + Hidroxiapatita + Colágeno 24h) em aumento de 1000x.

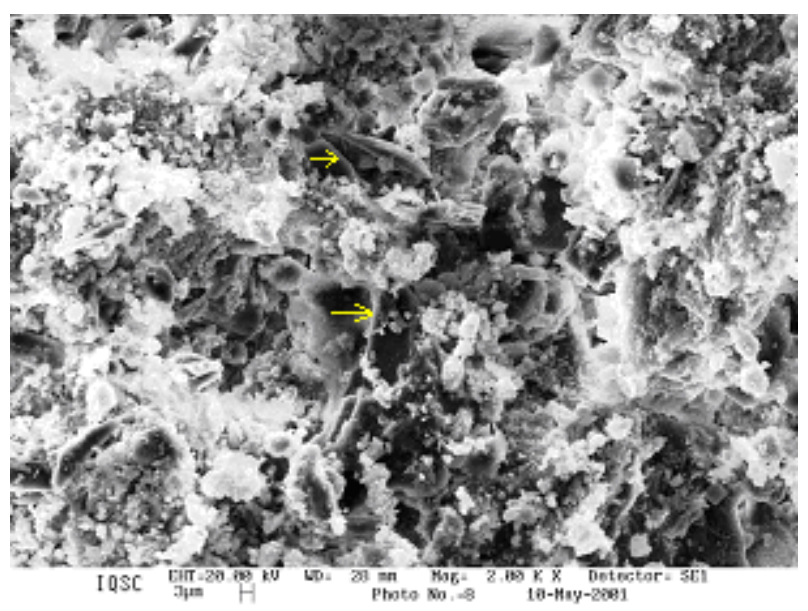

FIGURA 41. - Micrografia eletrônica de varredura da amostra do Compósito (Cimento Portland Branco + Hidroxiapatita + Colágeno 24h) em aumento de 2000x

\section{IV.3.3. - Espectroscopia de Dispersão de Energia de Raios -X (EDX) do grupo 3 (Cimento Portland Branco + Hidroxiapatita + Colágeno) (CPBHAC)}

As análises químicas de $\mathrm{Hg}$ e $\mathrm{Pb}$ determinadas por EDX (Figuras 43 e 44), variaram entre $0,04 \%$ e $0,67 \%$ e entre $0,06 \%$ e $0,64 \%$ respectivamente. Devido à sensibilidade da técnica utilizada, os valores referentes ao $\mathrm{Hg}$ e $\mathrm{Pb}$ apresentados na Tabela 4 e mostrados na Figura 42, poderão ser melhores analisados por outras técnicas, como por exemplo, espectroscopia de absorção atômica e comparados com a norma 
existente para biomateriais derivados da hidroxiapatita (ASTM-F-1581-95b). Outro característico referente aos metais pesados apresentados na Tabela 4, é que os mesmos parecem ser oriundos do cimento Portland branco, uma vez que ocorre uma diminuição em seu teor a medida em que é incorporado hidroxiapatita e colágeno.

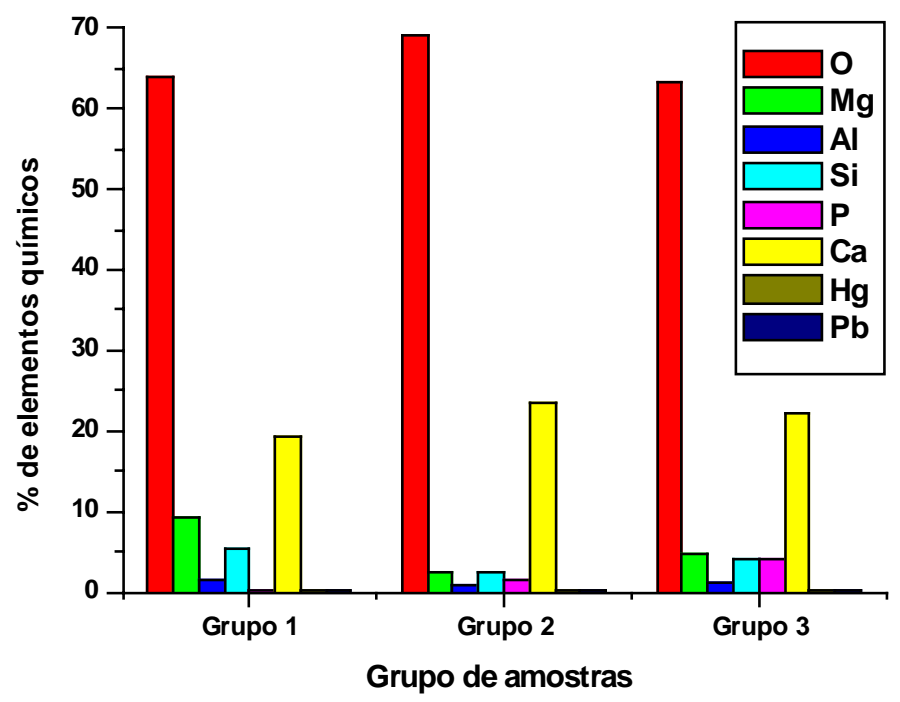

FIGURA 42. - Percentagem dos elementos nas amostras dos grupos 1,2 e 3.

Para os outros elementos presentes no material a técnica de EDX mostrou que o cimento Portland é um material extremamente heterogêneo (Tabela 4, grupo 1). Como por exemplo, no caso da sílica, a concentração deste elemento em diferentes regiões do material variou entre 0,18 até $8,05 \%$. Variações similares foram observadas também para o $\mathrm{Mg}, \mathrm{Al}, \mathrm{P}$ e Ca embora, quantitativamente as variações nas concentrações não mostrassem correlação alguma com a área analisada. As mesmas observações valem para os compósitos (cimento Portland:HA e cimento Portland:HA:colágeno). 
TABELA 4. - Resultados de Espectroscopia de Dispersão de Energia de Raios-X para as amostras dos grupos 1, 2 e 3, conforme a preparação citadas nos itens III.1.4, III.3.A.1 e III.3.B.1, respectivamente.

\begin{tabular}{|c|c|c|c|c|c|c|c|c|c|}
\hline \multicolumn{2}{|c|}{ Amostras } & $\mathbf{O}$ & Mg & Al & Si & $\mathbf{P}$ & Ca & Hg & $\mathbf{P b}$ \\
\hline \multirow{6}{*}{ 苍 } & $\begin{array}{l}(\mathrm{CPBW}) \\
\text { Figura } 24\end{array}$ & 66,82 & 10,23 & 1,06 & 6,00 & $0,06^{*}$ & 15,49 & $0,16^{*}$ & $0,17^{*}$ \\
\hline & $\begin{array}{c}(\mathrm{CPBW}) \\
\text { Figura } 25\end{array}$ & 66,35 & 11,48 & 0,99 & 6,79 & $0,24 *$ & 13,72 & $0,25^{*}$ & $0,18^{*}$ \\
\hline & $\begin{array}{l}\text { (CPBW) } \\
\text { Figura } 26\end{array}$ & 74,03 & 13,26 & $0,07 *$ & $0,18^{*}$ & $0,11^{*}$ & 12,25 & $0,04 *$ & $0,06^{*}$ \\
\hline & $\begin{array}{l}\text { (CPBW) } \\
\text { Figura } 27\end{array}$ & 43,48 & 2,48 & 1,95 & 8,05 & $0,63 *$ & 42,10 & $0,67 *$ & $0,64^{*}$ \\
\hline & $\begin{array}{l}(\mathrm{CPBW}) \\
\text { Figura } 28\end{array}$ & 68,39 & 8,46 & 2,90 & 5,95 & 0,52 & 13,08 & $0,35^{*}$ & $0,35^{*}$ \\
\hline & $\begin{array}{c}\text { Média com } \\
\text { desvio padrão }\end{array}$ & $63,81 \pm 11,77$ & $9,18 \pm 4,14$ & $1,39 \pm 1,07$ & $5,39 \pm 3,03$ & $0,31 \pm 0,25$ & $19,33 \pm 12,78$ & $0,29 \pm 0,24$ & $0,28 \pm 0,23$ \\
\hline \multirow{3}{*}{ 芑 } & $\begin{array}{c}\text { (CPBHAW) } \\
\text { Figura } 33\end{array}$ & 70,25 & 2,58 & 0,66 & 2,49 & 1,45 & 22,28 & $0,14^{*}$ & $0,16^{*}$ \\
\hline & $\begin{array}{l}\text { (CPBHAW) } \\
\text { Figura } 34\end{array}$ & 68,23 & 2,21 & 0,84 & 2,44 & 1,54 & 24,51 & $0,11^{*}$ & $0,11^{*}$ \\
\hline & $\begin{array}{c}\text { Média com } \\
\text { desvio padrão }\end{array}$ & $69,24 \pm 1,43$ & $2,39 \pm 0,26$ & $0,75 \pm 0,13$ & $2,47 \pm 0,04$ & $1,49 \pm 0,06$ & $23,39 \pm 1,58$ & $0,12 \pm 0,02$ & $0,13 \pm 0,04$ \\
\hline \multirow{5}{*}{ 奋 } & $\begin{array}{c}\text { (CPBHAC) } \\
\text { Figura } 43\end{array}$ & 67,67 & 6,11 & 0,96 & 6,05 & 3,81 & 15,23 & $0,04 *$ & $0,13^{*}$ \\
\hline & $\begin{array}{c}\text { (CPBHAC }) \\
\text { Figura } 44\end{array}$ & 63,10 & 5,92 & 0,91 & 3,49 & 4,97 & 21,22 & $0,24^{*}$ & $0,14^{*}$ \\
\hline & $\begin{array}{c}\text { (CPBHAC) } \\
\text { Figura } 44\end{array}$ & 63,50 & 3,45 & 1,02 & 4,67 & 3,90 & 22,86 & $0,25^{*}$ & $0,28^{*}$ \\
\hline & \begin{tabular}{|c|} 
(CPBHAC) \\
Figura 44
\end{tabular} & 59,51 & 3,47 & 1,74 & 1,98 & 2,99 & 29,78 & $0,36^{*}$ & $0,17^{*}$ \\
\hline & $\begin{array}{c}\text { Média com } \\
\text { desvio padrão }\end{array}$ & $63,45 \pm 3,34$ & $4,74 \pm 1,48$ & $1,16 \pm 0,39$ & $4,05 \pm 1,73$ & $3,92 \pm 0,81$ & $22,27 \pm 5,98$ & $0,19 \pm 0,10$ & $\mathbf{0 , 1 8} \pm \mathbf{0 , 0 7}$ \\
\hline
\end{tabular}

Grupo 1: Cimento Portland + Água

Grupo 2: Cimento Portland + Hidroxiapatita + Água

Grupo 3: Cimento Portland + Hidroxiapatita + Colágeno 

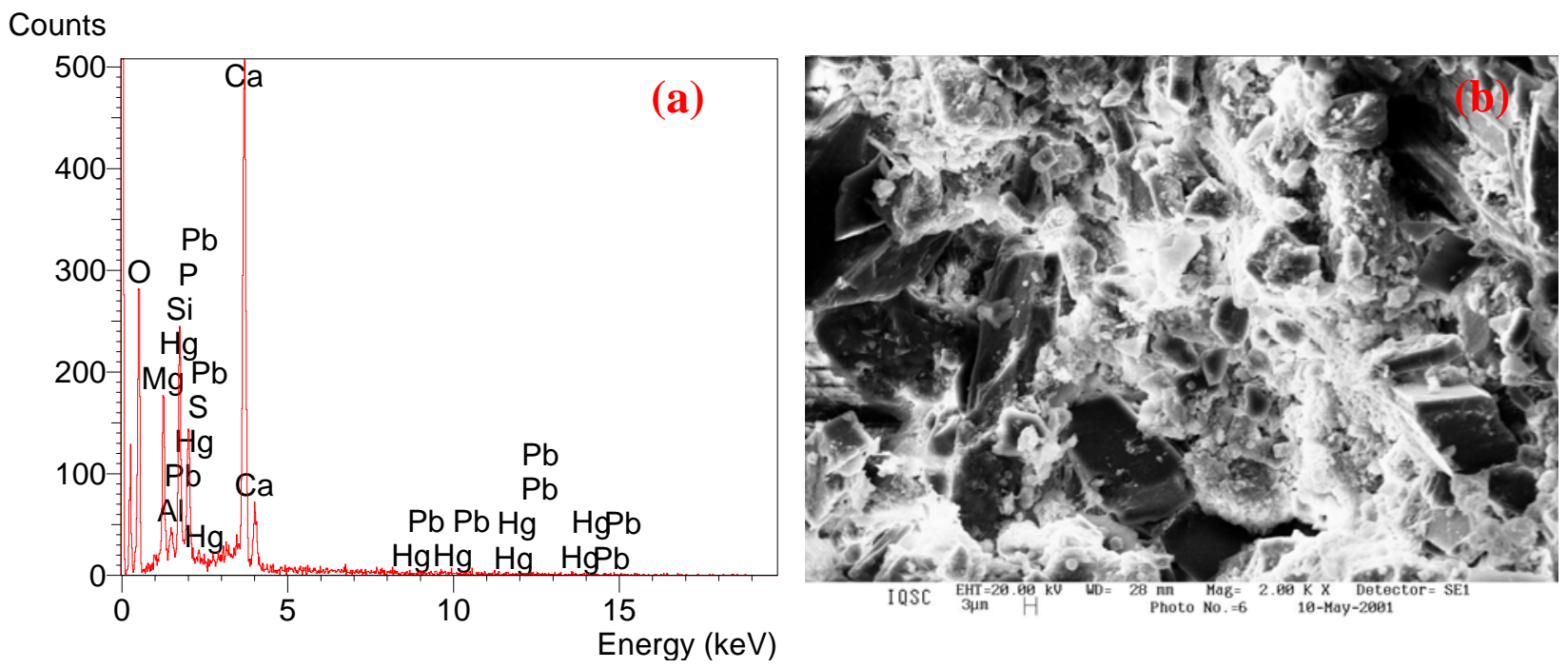

FIGURA 43. - (a) Curva de Espectroscopia de Dispersão de Energia de Raios-X e (b) Micrografia eletrônica de varredura da amostra do Compósito(Cimento Portland Branco + Hidroxiapatita + Colágeno 24h) em aumento de 2000x

zounts
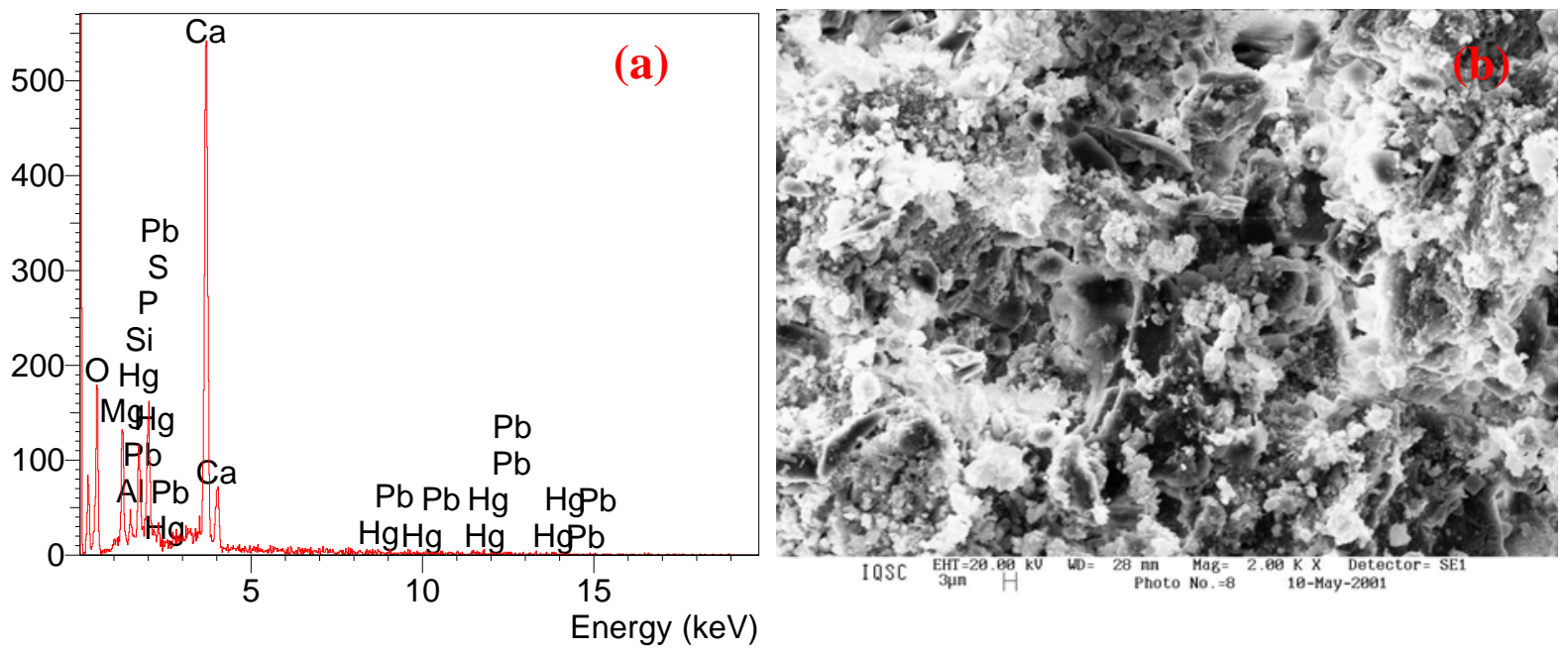

FIGURA 44. - (a) Curva de Espectroscopia de Dispersão de Energia de Raios-X e (b) Micrografia eletrônica de varredura da amostra do Compósito (Cimento Portland Branco + Hidroxiapatita + Colágeno 24h) aumento de 2000x

\section{IV.3.4. - Verificação da Radiopacidade do Compósito (CPBHAC) em relação ao Dente Humano com RX}

Nas tomadas radiográficas com filme periapical, pode ser observado que o grau de radiopacidade do Compósito (CPBHAC - Figura 45a) foi semelhante ao apresentado pela dentina no dente humano (Figura $45 \mathrm{~b}$ e c). Este resultado contribui para a proservação de um capeamento pulpar direto ou após uma pulpotomia onde a câmara 
pulpar é totalmente preenchida pelo material Compósito e a sua detecção pode ser verificada pelo exame de RX.

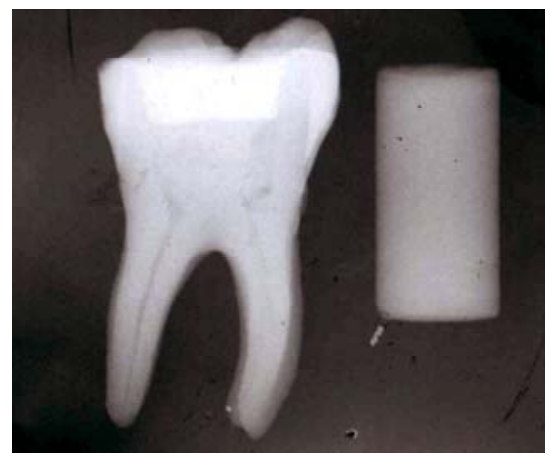

(a)

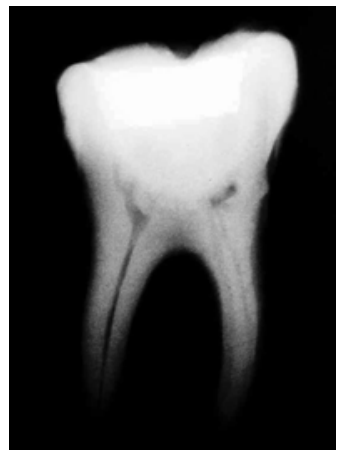

(b)

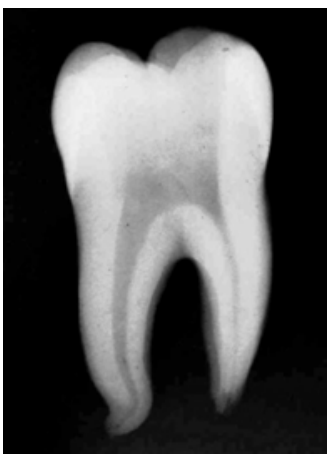

(c)

FIGURA 45. - (a) Raio-X periapical de um dente com Compósito( Cimento Portland + Hidroxiapatita + Colágeno 24h) na câmara pulpar ao lado do cilindro da amostra; (b) Dente com Compósito no interior da câmara pulpar; (c) Dente preparado para Pulpotomia.

\section{IV.4. - Considerações gerais do compósito (СРBHAC)}

Como citado no início do item III desta dissertação, os componentes deste Compósito já são utilizados individualmente em aplicações distintas como é o caso da HA, Col 24h e CPB. Em vários artigos pesquisados viu-se a biocompatibilidade e a biofuncionalidade como diretrizes para este trabalho que visa obter um material de uso para a odontologia com características próprias ímpares que vêm somar à Odontologia e mais especificamente à Endodontia soluções práticas e simples para grandes problemas dentários.

Qualquer tratamento conservador, quando corretamente indicado e executado mantém a normalidade fisiológica dos tecidos remanescentes. Considera-se importante para o sucesso de pulpotomia, a biocompatibilidade dos materiais utilizados, assepsia do campo operatório e o uso de instrumentos e técnicas atraumáticas.

A avaliação clínica cuidadosa do tecido pulpar remanescente é a mais importante, uma vez que a aparência da polpa dental pode não corresponder ao real estado histopatológico do tecido.

Um dos materiais que serve de parâmetro de comparação em se tratando de polpa dentária é sem dúvida nenhuma é o hidróxido de cálcio PA. Daí o estudo e hipóteses do mecanismo de ação do Compósito que podem ser similares ao biomaterial 
citado. Como o mecanismo de ação do hidróxido de cálcio não é totalmente dominado, apesar de ser um dos materiais com maior número de pesquisas e aplicações na Odontologia, pode-se dissertar acerca de prováveis mecanismos de ações e conseqüentemente transpô-las para o Compósito (CPBHAC).

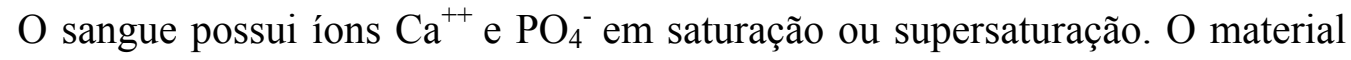
que contenha um ou ambos os elementos seria facilmente ionizável, quando em contato com a superfície da polpa. Qualquer fator que aumente a concentração de um ou de outro íon, portanto, tende a causar precipitação de fosfato tricálcico. A provável presença de íons $\mathrm{Ca}^{++}$proveniente da HA e do CPB presentes no Compósito permitirá a precipitação de $\mathrm{Ca}_{3}\left(\mathrm{PO}_{4}\right)_{2}$. Este depósito depende da enzima tipo fosfatase, que hidrolisa os fosfatos inorgânicos (BARBOSA, 1999). Para que isto ocorra, é necessário meio alcalino, que provê ambiente conveniente para a ação da enzima. Esta é a provável ação do Compósito que possibilita, pelo seu elevado pH semelhante ao do hidróxido de cálcio que é em torno de 12, o aumento da produção de fosfatos inorgânicos. Estes aumentam a precipitação do composto solúvel $\mathrm{Ca}_{3}\left(\mathrm{PO}_{4}\right)_{2}$. O material orgânico Colágeno presente no Compósito e na polpa dentária provavelmente servirá de matriz para depósito.

Em relação ao $\mathrm{pH}$ elevado que o compósito cimento Portland:HA:colágeno produz quando exposto ao meio aquoso, este não parece ser um problema pois, é um pH similar produzido pelo hidróxido de cálcio. O hidróxido de cálcio produz necrose superficial motivada pela sua alcalinidade, estando separado da polpa normal por depósito linear de proteinato de cálcio (HOLLAND et al., 1975). A localização e situação do proteinato de cálcio, provavelmente, representa a ação em profundidade da substância, a qual finalmente reage com a proteína do tecido para formar a matriz da nova estrutura dentinária.

Com relação à hidroxiapatita exceto a posição do grupo $\mathrm{OH}$, todas as outras posições atômicas de sua fórmula $\left[\mathrm{Ca}_{10}\left(\mathrm{PO}_{4}\right)_{6} \mathrm{OH}_{2}\right]$, são essencialmente iguais como as da fluorapatita $\left[\mathrm{Ca}_{10}\left(\mathrm{PO}_{4}\right)_{6} \mathrm{~F}_{2}\right]$ e ambas estão presentes nos dentes.

A estrutura da hidroxiapatita permite substituições catiônicas e aniônicas isomorfas com grande facilidade ( MA et al., 1994).

A hidroxiapatita é eficiente em reduzir não só a solubilidade dos complexos de $\mathrm{Pb}$, como também sua biodisponibilidade. Sugere-se, ainda, que a mesma seria seis 
vezes mais efetiva na remoção de Chumbo do que as rochas de fosfato devido a diferenças de solubilidade (RYAN \& ZHANG, 1996).

MA et al., (1994), pesquisaram o efeito da presença de metais tais como o $\mathrm{Zn}$, $\mathrm{Cd}, \mathrm{Ni}, \mathrm{Cu}, \mathrm{Fé}^{+2} \mathrm{e} \mathrm{Al}$ na imobilização de $\mathrm{Pb}$ pela hidroxiapatita.

$\mathrm{O} \mathrm{Ca}^{2+}$ pode ser substituído por metais tais como o $\mathrm{Zn}^{2+}, \mathrm{Cd}^{2+}, \mathrm{Ni}, \mathrm{Cu}^{2+}, \mathrm{Sr}^{2+}$, $\mathrm{Co}^{2+}, \mathrm{Fe}^{2+}, \mathrm{Pb}^{2+}, \mathrm{Hg}^{+2}$, etc; os grupos fosfatos por carbonatos e vanadatos e as hidroxilas por carbonatos, flúor e cloro (MAVROPOULOS, E. 1999).

Em relação à presença do colágeno, o esperado é atuar com as propriedades que tem no tecido vivo, isto é, o potencial indutor e organizador de tecido do colágeno em questão. Muito desses derivados já são usadas clinicamente na reconstrução de defeitos periodontais, implantologia e reconstrução de tecido. Os resultados têm mostrado que o Colágeno Aniônico (CA), denominação dada a matrizes de colágeno com grupos carboxílicos adicionais, se comporta com propriedades que não são inerentes e que tem sido descritas na literatura para Matrizes Extracelulares (MECs) preparadas para enxerto tecidual. Este comportamento inclui o aumento na adesão e proliferação celular (BET et al., 2003), ausência de resposta inflamatória (ROCHA et al., 2002; PARREIRA, 2004; ROSA et al., 2003; MIGUEL, 2003), incorporação pelos tecidos e a metaplasia óssea. Entretanto o que mais chamou a atenção foi à deposição de sais de fosfato de cálcio sobre a sua estrutura tanto in vitro quanto in vivo (GOISSIS et al., 2003).

Outro fato importante é a liberação de água do Compósito desde o instante $\mathrm{t}=0$ de sua manipulação que deve estabilizar a hidrodinâmica da polpa e dentina.

Embora os resultados de TG, DSC, FTIR, MEV, EDX e pH mostrarem uma grande semelhança química entre o CPB e o MTA, os resultados deste trabalho ainda são preliminares, mas a expectativa, principalmente levando-se em consideração as propriedades do colágeno utilizado é que o compósito preparado possa ser de utilidade na Endodontia em capeamento pulpar direto e em pulpotomia. Há a necessidade de desenvolver em próximas etapas as avaliações da Biocompatibilidade e da Biofuncionalidade. 


\section{CONCLUSÕES}

O material Compósito (CPBHAC) obtido de forma economicamente viável, sugere possibilidade de usos na Endodontia e a sua principal inovação em relação aos materiais similares existentes é a presença do Colágeno Aniônico e da Hidroxiapatita Sintetizada. Foram observadas fibras colagênicas em micrografias de MEV, partículas de HA e silicatos do CPB interconectadas pelas mesmas.

Um fator importante como Biomaterial foi a preservação da estrutura da hélice tripla do colágeno conforme análise dos resultados indicados pelas técnicas de estabilidade térmica e FTIR.

Pode-se sugerir que o Compósito (CPBHAC) poderá influenciar, positivamente, na reparação tecidual da polpa dentária mantendo a normalidade fisiológica dos tecidos remanescentes para a formação da nova matriz dentinária de uma forma "mais natural”, necessitando, portanto, pesquisas futuras de biocompatibilidade e biofuncionalidade “in vivo”, para Capeamento Pulpar Direto e Pulpotomia. 


\section{REFERENCIAS}

ABEDI, H.R.; INGLE,J.I. (1995). Mineral trioxide aggregate a review of a new cement. Journal of the California Dental Association, Sacramento, v.23, n.12, p.3639.

ABRAMS, H.; CUNNINGHAM, C.J.; LEE, S.B. (1992). Periodontal changes following coronal / root perfuraton and formocresol pulpotomy. Journal of Endodontics, Chicago, v.18, n.8, p.399-402.

ADRIAENS, P.A.; DE BOEVER, J.A.; LOESCHE, W.J. (1988). Bacterial invasion in root cementum and radicular dentin of periodontally diseased teeth in humans. A reservoir of periodontopathic bacteria. Journal of Periodontology, Birmingham, v.59, p.222-230.

ALBEE, F.H. (1920). Studies in bone growth triple calcium phosphate as stimulus to osteogenesis. Annals of Surgery, Philadelphia, v.71, p.32-36.

AOKI, H. (1991). Science and medical aplications of hydroxyapatite. Tokyo: Japannese Association of Apatite Science.

ARAKI, K. et al. (1993). Excretion of ${ }^{14} \mathrm{C}$-formaldehyde distributed systemically through root canal following pulpectomy. Endodontics and Dental Traumatology, Copenhagen, v.9, p.69-99.

AMERICAN SOCIETY FOR TESTING AND MATERIALS (1986). F451-86: Standard specifications for acrylic bone. Philadelphia, p.97-103.

AVERY, J.K. (1971). Structural elements of the young normal human pulp. Oral Surgery, Tokyo, v.32, n.1, p.113-125.

(1981). Repair potencial of pulp. Journal of Endodontics, Chicago, v.7, n.5,

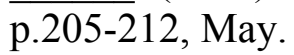

AYDOS, J.H. (1985). Tratamento da polpa dental inflamada. Revista da Faculdade de Odontologia de Porto Alegre, Porto Alegre, v.27, p.153-171.

BARBOSA, S.V. (1999). Terapêutica endodôntica. São Paulo: Santos.

BARBOSA, S.V.; ARAKI, K.; SPANGBERG, L.S.W. (1993). Citotoxicity of some modified root canal sealers and their leachable components. Oral Surgery, Tokyo, v.75, p.357-361.

BAUMANN, W.R.G. (1984). Estudo radiográfico das reabsorções dentais ocasionadas por tratamento ortodôntico. Tese (Mestrado) - Universidade Federal de Santa Catarina, Florianópolis, 1984.

BERNABÉ, P.F.E. (1994). Estudo histopatológico realizado em dentes de cães com lesão periapical após apicectomia e tratamento endodôntico via retrógrada: influência do nível da obturação e do material obturador. 352p. Tese (Livre Docência) 
- Faculdade de Odontologia de Araçatuba, Universidade Estadual Paulista, Araçatuba, 1994.

BET, M.R. (2000). Colágeno aniônico: propriedades físico-químicas, estruturais e comportamento biológico. 107p. Tese (Doutorado) - Instituto de Química de São Carlos, Universidade de São Paulo, São Carlos, 2000.

BET, M.R. et al. (2003). Cell adhesion and cytotoxicity studies over polyanionic collagen surfaces with variable negative charge and wettability. Biomaterials, Guildford, v.24, n.1, p.131-137, Jan.

BERBERT, A.; BRAMANTE, C.M.; BERNARDINELI, N. (1980). Endodontia prática. São Paulo: Sarvier.

BEHNIA, A. et al. (2000). Repairing iatrogenic root perfurations. Journal of the American Dental Association, Chicago, v.131, n.2, p.196-201, Feb.

BIMSTEIN, E. (1985). Pulpotomy treatment in primary teeh. Compendium of Continuing Education in Dentistry, Jamesburg, v.6, n.8, p.586-591, Sept.

BLOCK, R.M. et al. (1983). Sistemic distribution of $\left[{ }^{14} \mathrm{C}\right]-$ labeled paraformaldehyde incorporated within Formocresol following pulpotomies in dogs. Journal of Endodontics, Chicago, v.9, n.5, p.176-89.

BOZZO, L.; HIZATUGU, R. (1973). Reparação dos tecidos periapicais. Revista Brasileira de Odontologia, Rio de Janeiro, v.13, p.180-183.

BRANSTETTER, J.; FRAUNHOFER, J.A. (1982). The physical properties and sealing action of endodontic sealer cements; a review of the literature. Journal of Endodontics, Chicago, v.8, n.7, p.312-316, July.

BRAMANTE, C.M. et al. (2003). Acidentes e complicações no tratamento endodôntico - soluções clínicas. São Paulo: Santos.

BURCH, J.G.; HULEN, S. (1974). A study of the presence of accessory foramina and the topography of molar furcations. Oral Surgery, Tokyo, v.38, p.451-455, Sept.

BURET, A. et al. (1991). An in vivo model to study the pathology of infectious biofilms on biomaterial surfaces. Journal of Biomedical Materials Research, New York, v.25, p.865-874.

BUSATO, A.L.S. et al. (2000). Agregado de trióxido mineral indicações clínicas de um novo cimento. Jornal Brasileiro de Odontologia Clínica, v.3, n.18, p.32-34.

CALLISTER JR., W.D. (1991). Materials science and engennering-an introduction. $2^{\text {nd }}$ ed. New York: John Wiley.

. (2002). Ciência e engenharia de materiais: uma introdução. 5.ed. Rio de Janeiro: Livros Técnicos e Científicos.

CAMBRUZZI, J.V.; GREENFELD, R.S. (1983). Necrosis of crestal boné related to the use of excessive formocresol medication during endodôntico treatment. Journal of Endodontics, Chicago, v.9, n.12, p.565-67. 
CARR, G.B. (1992). Microscopes in endodontics. Journal of the California Dental Association, Sacramento, v.20, n.11, p.55-61, Nov.

CHAPMAN, J.A. et al. (1990). The collagen fibril-a model system studying the staining and fixation of protein. Electron Macroscopy Reviews, Langsford, v.3, n.1, p.143-182.

CHEN, Y.S. et al. (2000). Peripheral nerve regeneration using silicone rubber chambers filled with collagen, laminin and fibronectin. Biomaterials, Guildford, v.21, n.15, p.1541-1547, Aug.

COHEN, S.; BURNS, R.C. (1982). Caminhos da polpa. Tradução de Sylvio Bevilacqua. 2.ed. Rio de Janeiro: Guanabara Koogan.

COHEN, S. C. (1979). Human pulpal response to bleaching procedures on vital teeth. Journal of Endodontics, Chicago, v.5, p.134-138.

CORDEIRO, R. et al. (1995). A inadequação dos valores dos limites de tolerância biológica para prevenção da intoxicação profissional pelo chumbo no Brasil. Cadernos de Saúde Pública, Rio de Janeiro, v.11, n.2, p.177-186.

COSTA JR., E.D.; BARBOSA, S.V. (1992). Permeabilidade, infiltração e tempo de presa de cimentos modificados. Odonto 10, v.2, n.4, p.307-310.

COX, C.F. et al. (1982). Camping of the dental pulp mechanically exposed to the oral microflora- a 5 week observation of wound healing in the monkey. Journal Oral Pathology, Copenhagen, v.11, n.4, p.327-339, Aug.

(1985). Pulp capping of the dental pulp mechanically exposed to oral microflora: a 1-2 year observation of wound healing in the monkey. Journal Oral Pathology, Copenhagen, v.14, n.2, p.156-168, Dec.

DAS, S.; DAS, A.K.; MURPHY, R.A. (1997). Experimental apexigenesis in baboons. Endodontics and Dental Traumatology, Copenhagen, v.13, n.1, p.31-35, Feb.

DAVIES, J.E. (1990). The bone material interface. Toronto: University of Toronto Press.

DE DEUS, Q.D. (1986). Endodontia. 4.ed. Rio de Janeiro: Medsi.

DEGEE, A.J.; WU, W.K.; WESSLINK, P.R. (1994). Sealing properties of ketac-endo glass ionomer cement and $\mathrm{AH} 26$ root canal sealers. International Endodontic Journal, London, v.27, p.239-244, Sept.

DE MARTIN, A.S. et al. (2004). Perfuração lateral de raiz selada com MTA. JBE: Jornal Brasileiro de Endodontia, Curitiba, v.5, p.10-13.

DEZAN, JR.; HOLLAND, R. MAURO, S.J. (1995) Capeamento pulpar e pulpotomia com o sistema All Bond I: estudo in vitro. In: REUNIÃO CIENTÍFICA DA SOCIEDADE BRASILEIRA DE PESQUISAS ODONTOLÓGICAS, 12., 1995, São Paulo. Anais... São Paulo: SBPqO. p.27, res.54. 
DIAS, A.T. (1980). Manual de endodontia. Rio de Janeiro: Guanabara Koogan.

DODD, C.M.; CARMICHAELK, D.J. (1979). The collagenous matrix of bovine predentin. Biochemica et Biophysica Acta: protein structure, Amsterdam, v.577, n.1, p.117-124, Mar.

DOYLE, W.A.; McDONALD, R.E.; MITCHELL, D.F. (1962). Formocresol versus calcium hydroxide in pulpotomy. Journal of Dental Children, p.86-97.

DRIESSENS, F.C.M. et al. (1994). Effective formulations for the peparation of calcium phosphate bone ciments. Journal of Materials Science: materials in medicine, v.5, p.164-170.

DUARTE, C.A. (2003). Cirurgia periodontal - pré-protética e estética. 2.ed. São Paulo: Santos.

EHNEVID, H. et al. (1995). Endodonticas pathogens; propagation of infection through patent dentinal tubules in traumatized monkey teeth. Endodontics and Dental Traumatology, Copenhagem, v.11, p.229-234.

ESTRELA, C. et al. (2000). Antimicrobial and chemical study of MTA, Portland cement, calcium hydroxide paste, sealapex and Dycal. Brazilian Dental Journal, Ribeirão Preto, v.11, p.19-27.

EVANS, G.R.D. et al. (1999). In vivo evaluation of poly(-lactic acid) porous conduits for pheripheral nerve regeneration. Biomaterials, Guildford, v.20, n.12, p.1109-1115, June.

EY, D.J. et al. (1996). Stabilized polyglycolic acid fibre-based tubes for tissue engineering. Biomaterials, Guildford, v.17, n.2, p.115-124, Jan.

FIGÚN, M.E.; GARINO, R.R. (1980). Anatomia odontológica funcional y aplicada. Buenos Aires: El Ateneo.

FISH , E.W. (1939). Bone infection. Journal of the American Dental Association, Chicago, v.26,p.691-712.

FORD, T.P. et al. (1996). Using mineral trióxido aggregate as a pulp-capping material. Journal of the American Dental Association, Chicago, v.127, n.10, p.1491-1493, Oct.

FOWLER, B.O. (1974). Infrared studies of apatites: vibracional assigments for calcium, strontium, and barium hydroxyapatites utilizing isotopic substitution. Inorganic Chemistry, Easton, v.13, n.1, p.194-207.

GALLOP, P.M.; BLUMENFELD, O.O.; SEIFTER, S. (1967). Subunits and special structural features of tropocollagen. In: RAMACHANDRAN, G.N. (Ed.). Treatise on collagen. London: Academic Press. v.3.

GAO, Y. et al. (1995). Induction of reparative dentin formation in dogs by bovine bne morphogenetic protein bound to ceramic dentin. Journal of Osaka Dental University, Osaka, v.29, n.1, p.29-38, Apr. 
GAO, Y. et al. (1995). The inductive effect of bone morphogenetic protein (BMP) on human periodontal fibroblast-like cells in vitro. Journal of Osaka Dental University, Osaka, v.29, n.1, p.9-17, Apr.

GARVIN, K.L. et al. (1994). Polylactide/polyglycolide antibiotic implants in treatment of osteomyelitis. Journal Bone and Joint Surgery, London, v.76-A, n.10, p.15001506 , Oct.

GHOSE, L.J.; BAGHDADY, V.S.; HIKMAT, B.Y.M. (1987). Apexification of immature apices of pulpess permanent anterior teeth with calcium hydroxide. Journal of Endodontics, Chicago, v.13, n.6, p.285-290, June.

GOISSIS, G.; PLEPIS, A.M.G.; J.L. (1994). Processo de extração de colágeno em tecidos animais com auxílio de solvente orgânico em meio alcalino. BR. PI 9.405.043-0.

GOISSIS, G.; PLEPIS, A.M.G.; ROCHA, J.L. (1996). Processo de extração de colágeno de tecidos animais com auxílio de solvente orgânico em meio alcalino. BR9.405.043-0.

GOISSIS, G.; MAGINADOR, S.V.S.; MARTINS V.C.A. (2003). Biomimetic mineralization of charged collagen. Matrices: in vitro and in vivo study. Artificial Organs, Cleveland, v.27, n.5, p.425-431, May.

GOLDBERG, F. (1981). Relation between corroded silver points and endodontic failures. Journal of Endodontics, Chicago, v.7, n.5, p.224-227, May.

GOLDBERG, F. et al. (1987). Accessory orifaces: anatomical relationship between the pu- lup chamber floor and the furcation. Journal of Endodontics, Chicago, v.13, n.4, p.176-181, Apr.

GORDON, P.L. et al. (1974). The far infra-red spectrum of collagen. Macromolecules, Washington, v.7, n.6, p.954-956, Nov.

GRISTINA, A.G. (1987). Biomaterial-centered infection: microbial adhesion versus tissue integration. Science, Washington, v.237, n.4822, p.1588-1595, Sept.

GUTMANN, J. L. (1978). Prevalence location and potency of accessory in the furcation region of permanent molars. Journal of Periodontology, Birmingham, v.19, p.21-26.

GUY, A.G. (1980). Ciências de materiais. Tradução de José Roberto G.da Silva. Rio de Janeiro: Livros Técnicos e Científicos.

GRIEVE, A.R.; PARKHOLM, J.D.O. (1973). The sealing properties of root fillings cements. British Dental Journal, London, v.135, n.7, p.327-331, Oct.

GROSSMAN, L.I.; SHAPIRO, I.M.; IAQUINTA, S. (1974). Lead blood levels after use of N2. In: MEETING AMERICAN ASSOCIATION ENDODONTICS, 1974. Proceedings... [S.1.:s.n] 
HAHN, C.L.; FALKLER JR., W.A.; SIEGEL, M.A. (1989). A study of T and B cells in pulpal pathosis. Journal of Endodontics, Chicago, v.15, n.1, p.20-26, Jan.

HALSE, A.; MOLVEN, O. (1986). A strategy for the diagnosis of periapical pathosis. Journal of Endodontics, Chicago, v.12, n.11, p.534-538, Nov.

HAM, A.W. (1963). Histologia. 3.ed. Rio de Janeiro: Guanabara Koogan.

HATA, G. et al. (1989). Systemic distribution of ${ }^{14} \mathrm{C}$-labeled formaldehyde applied in the root canal following pulpectomy. Journal of Endodontics, Chicago, v.15, n.11, p.539-543.

HAMERSKY, P.A.; WEIMER, A.D.; TAINTOR, J.F. (1980). The effect of orthodontic force application on the pulpal tissue respiration rate in the human premolar. American Journal of Orthodontics, St.Louis, v.77, p.68-74.

HEMMERLE, J.; LEIZE, M.; VOEGEL, J.C. (1995). Long-term behavior of a hydroxyapatite/collagen-glycosaminoglycan biomaterial used for oral surgery: a case report. Journal Materials Science: materials in medicine, London, v.6, n.6, p.360-366, June.

HENCH, L.L. (1991). Bioceramics: from concept to clinic. Journal of the American Ceramic Society, Easton, v.74, n.7, p.1487-1510, July.

HERMANN B. W. (1920). Dentinobliteration der wurzer kanale nach. Behandlung mit calcium. Zahnartzl Resch., v.39, p.888.

HEYS, D.R. et al. (1985). The inherent healing capacity of the dental pulp. Journal of Dental Research, Chicago, v.64, p.221-226.

HOLLAND, R.; SOUZA, V. (1984). Quando e como o clínico deve realizar o tratamento conservador pulpar. ln: BOTTINO, M.A.; FELLER, C. (Coord.). Atualização clínica em odontologia. São Paulo: Artes Médicas. Cap.3.2, p.89-117.

HOLLAND, R.; SOUZA, V.; RUSSO, M.C. (1975). Tratamento conservador da polpa dental. ARS Curandi em Odontologia, São Paulo, v.2, n.2, p.3-17.

HOLLAND, R.et al. (1978). Influência dos fragmentos de dentina no resultado do tratamento conservador da polpa dental exposta ou inflamada. Ver. Gaúcha Odontol. v.26, n.2, p.98-102, abr/jun.

. (1981). The influence of the sealing material in the healing process of inflamed pulps capped with calcium hydroxide or zinc oxide eugenol cement. Acta de Odontologia Pediátrica, Santo Domingo, v.2, n.1, p.5-9.

- (1996). Apostila de endodontia. Araçatuba: Faculdade de Odontologia/UNESP. Apostila

(2001). Mineral trioxide aggregate repair of lateral root perforations. Journal of Endodontics, Chicago, v.27, n.4, p.281-284, Apr. 
(2001a). Reaction of rat connective tissue to implanted dentin tube filled with mineral trioxide aggregate, Portland cement or calcium hydroxide. Brazilian Dental Journal, Ribeirão Preto, v.12, p.3-8.

. (2002). Reaction of rat connective tissue to implanted dentin tubes filled with a white mineral rioxide aggregate. Brazilian Dental Journal, Ribeirão Preto, v.13, n.1, p.23-26.

HSU, Y.; KIM, S. (1997). The resected root surface. Dental Clinics of North America, Philadelphia, v.41, p.529-40.

HUC, A. (1985). Collagen biomaterials characteristics and applications. Journal American Leather Chemists Association, Lubbock, v.80, p.195-212.

HUME, W.R. (1986). The pharmacologic and toxicological properties of zinc oxideeugenol. Journal of the American Dental Association, Chicago, v.113, p.789-791.

INGLE, J.I. (1979). Endodontia. Tradução de José Carlos Borges. 2.ed. Rio de Janeiro: Interamericana.

INGLE, J.I. \& TAINTOR, J.F. (1985). Endodontics. $3^{\text {rd }}$ ed. Philadelphia: Saunders.

IPSC (1995). International programme on chemical safety: environmental health criteria 165 for inorganic lead.

ITO, M. (1991). In vitro properties of a chitosan-bonded hydroxyapatite bone filling paste. Biomaterials, Guildford, v.12, n.1, p.41-45, Jan.

JANSEN, B.; KOHNEN, W. (1995). Prevention of biofilm formation by polymer modification. Journal of Industrial Microbiology, Amsterdam, v.15,p.391-396.

JARCHO, M. et al. (1976). Hydroxylapatite synthesis and characterization in dense polycrystalline form. Journal Materials Science, Norwell, v.11, n.11, p.2027-2035.

JUNQUEIRA, L.C.; CARNEIRO, J. (1999). Histologia básica. 9.ed. Rio de Janeiro: Guanabara Koogan.

JURCAK, J.J. et al. (1992). In vitro intracanal temperatures produced during warm lateral condensation of gutta-percha. Journal of Endodontics, Chicago, v.18, n.1, p.13.

KATZ, A. et al. (1987). Rejuvenation of brittle gutta-percha cones - a universal technique. Journal of Endodontics, Chicago, v.13, n.2, p.65-69.

KAWAI, K. et al. (2000). Accelerated tissue regeneration through incorporation of basic fibroblast growth factor-impreganated gelatin microspheres into artificial dermis. Biomaterials, Guildford, v.21, n.5, p.489-499, Mar.

KAZIM, M. et al. (1992). Evaluation of a collagen/hydroxyapatite implant for orbital reconstructive surgery. Ophthalmic Plastic and Reconstrutive Surgery, v.8, n.2, p.94-108. 
KEDECI, P.S.; ERSOY, E. (1987). An alternate endodontic approach to periapical pathosis. Oral Surgery, Tokyo, v.64, n.6, p.742-56.

KIM, S. (1985). Microcirculation of the dental pulp in health and disease. Journal of Endodontics, Chicago, v.11, p.465-469.

- (1990). Neurovascular interactions in the dental pulp in health and inflammation. Journal of Endodontics, Chicago, v.16,p.48-53.

KIM, B.; MOONEY, D.J. (1998). Development of biocompatible synthetic extracellular matrices for tissue engineering. Trends in Biotechnology, v.16, p.224230.

KOCH, K.; MIN, P.S.; STEWART, G.G. (1994). Comparison of apical leakage between ketac-endo sealer and grossman sealer. Oral Surgery, Tokyo, v.78, n.6, p.784-787.

KOENIGS, J.D.; BRILLIAN, J.D.; FOREMAN, D.W. (1974). Preliminary scanning electron microscope investigations of accessory foramina in the furcation areas of human molar teeth. Oral Surgery, Oral Medicine, Oral Pathology, and Radiology and Endodontics, St.Louis, v.38, n.5, p.773-782.

KOENIGS, J.F. et al. (1975). Induced apical closure of permanent teeth in adult primates using a resorbable form of tricalcium phosphate ceramic. Journal of Endodontics, Chicago, v.1, p.102, Mar.

KONTTINEN, Y.T. et al. (1989). Cellular and molecular aspects of inflammation. Proceedings of the Finnish Dental Society, Helsinki, v.85, n.2, p.95-107.

LANGELAND, K.; OLSSON, B.; PASCON, E.A. (1981). Biological evaluation of Hydron. Journal of Endodontics, Chicago, v.7, n.5, p.196-204.

LANGER, R.; VACANTI, J.P. (1993). Tissue engineering. Science, Washington, v.260, p.920-925.

LARINI, L. (1993). Toxicologia. 2.ed. São Paulo: Manole.

LEE, S.; TOREBINEJAD, M. (1993). Sealing ability of mineral trioxide aggregate for repair of lateral root perfotatin. Journal of Endodontics, Chicago, v.19, n.11, p.541544.

LEONARDO, M.R.; LEAL, J.M.; SIMÕES FILHO, A.P. (1982). Endodontia: tratamento de canais radiculares. São Paulo: Panamericana.

LEVITT, S.R. et al. (1969). Forming methods for apatite prosthesis. Journal of Biomedical Materials Research, New York, v.3, n.4, p.683-685, Dec.

LEGEROS, R.Z. (1988). Calcium phosphate materials in restorative dentistry: a review. Advances in Dental Research, Washington, v.2,p.164-180.

LEWIS, R.D.; BLOCK, R.M. (1988). Management of endodontic failures. Oral Surgery, Tokyo, v.66, n.8, p.711-721. 
LIM, K.C.; TIDMARSH, B.G. (1986). The sealing ability of Sealapex compared with AH26. Journal of Endodontics, Chicago, v.12, n.12, p.564-566.

LIM, K.C.; KIRK, E.E.J. (1987). Direct pulp capping: a review. Endodontics and Dental Traumatology, Copenhagen, v.3, p.213-219.

LIMA, A.C.F.A.; MORAES, V.R. \& GARROCHO,A.A. (1986). Pulpotomia: alternativa à exodontia. Arq. Cent. Est. Cur. Odontology, v.23, n.1-2, p.19-33.

LOPES, H.P.; COSTA FILHO, A.S. (1987). A pulpotomia como opção no atendimento ambulatorial: estudo preliminar. Revista Brasileira de Odontologia, Rio de Janeiro, v.44, n.6, p.50-66.

LOWMAN, J.V.; BURKE, R.S.; PELLEN, G.V. (1973). Patent accessory canals: incidence in molar furcation region. Oral Surgery, Tokyo, v.36, p.580, Oct.

MA, Q.Y. et al. (1994). Effects on NO3-, Cl-, F-, SO42-, and CO32- on $\mathrm{Pb} 2+$ immobilization by hydroxyapatite. Environmental Science \& Technology, Easton, v.28, n.3, p.408-418, Mar.

MA, P.X.; ZHANG, R. (1999). Synthetic nano-scale fibrous extracellular matrix. Journal of Biomedical Materials Research, New York, v.46, n.1, p.60-72, July.

MAGNUSSON, B. (1971). Therapeutic pulpotomy in primary molars-clinical and histological follow-up. [S.1.:s.n.].

MAGNUSSON, B.O. (1980). Pulpotomy in primary molars: long-term clinical and histological evaluation. International Endodontic Journal, London, v.13, p.143-155.

MANN, S.; WEBB, J.; WILLIAMS, R.J.P. (Ed.). (1989). Biomineralization: chemical and biochemical perspectives. Weinheim: $\mathrm{VCH}$.

MARLIN, J.; SCHILDER, H. (1973). Physical properties of gutta percha whe subject to heat na vertical condensation. Oral Surgery, Tokyo, v.36, p.872, Dec.

MATSUMIYA, S. (1955). Atlas of oral pathology. Tokyo: Tokyo Dental College Press.

MAVROPOULOS, E. (1999). A hidroxiapatita como absorvedor de metais. 105p. Tese (Mestrado) - Fundação Oswaldo Cruz, Escola Nacional de Saúde Pública, Rio de Janeiro, 1999.

MELO, M.F.F. (1982). Análise dos principais cimentos utilizados para obturação de canais radiculares, com relação a sua composição e tempo de presa. Natal: Faculdade de Odontologia/UFRN. Monografia.

MENDONZA, M.M. et al. (1987). An ultrastructural investigation of the human apical pulp in irreversible pulpitis. II - vasculature and connective tissue. Journal of Endodontics, Chicago, v.13, n.7, p.318-327. 
MENEZES, R. et al. (2003). Microscopic analysis of the tissue response of dog's teeth after pulp capping with two types of mineral trioxide aggregate. Journal of Dental Research, Chicago.

MICHELICH, V.J.; SCHUSTER, G.S.; PASHLEY, D.H. (1980). Bacterial penetration of human dentin in vivo. Journal of Dental Research, Chicago, v.59, p.1398-1403.

MIGUEL, F.B. (2003). Avaliação morfológica do comportamento de matrizes tridimensionais de colágeno aniônico na regeneração óssea em rato. $125 \mathrm{p}$. Dissertação (Mestrado) - Faculdade de Odontologia, Universidade Federal da Bahia, Salvador, 2003.

MODAK, S.M. et al. (1987). A new method for the direct incorporation of antibiotic in prothestic vascular grafts. Surgery Gynecology and Obstetrics, Chicago, v.164, n.2, p.143-147, Feb.

MOONEY, D.J. et al. (1996). Stabilized polyglycolic acid fibre-based tubes for tissue engineering. Biomaterials, Guildford, v.17, n.2, p.115-124, Jan.

. (1997). Long-term engraftment of hepatoytes transplanted on biodegradable polymer sponges. Journal of Biomedical Materials Research, New York, v.37, n.3, p.413-420, Dec.

MONROE, et al. (1971). New calcium phosphate ceramic material for bone and tooth implants. Journal of Dental Research, Chicago, v.50, n.4, p.860-862, July.

MORSE, D.R. (1977). Immunologic aspects of pulpal-periapical diseases. Oral Surgery, Tokyo, v.43, n.3, p.436-450.

MORSE, D.R.; LARNIE, J.O.; YESILSOY, C. (1990). Apexification: review of the literature. Quintessence International, Carol Stream, v.21, n.1, p.589-598, July.

NAKASHIMA, M. (1994). Induction of dentin formation on canine amputated pulp by recombinant human bone morphogenetic proteins (BMP) -2 and -4 . Journal of Dental Research, Chicago, v.73, n.9, p.1515-1522, Sept.

NERY, E.B. et al. (1975). Bioceramic implants in surgically produced infrabony defects. Journal of Periodontology, Bermingham, v.46, n.6, p.328-339.

NEVES, J. B. (2001). Otimização da estética. Implantodontia Oral, v.3, p.35-55.

NIMNI, M.E. (Ed.). (1988). Collagen. Florida: CRC. v.1.

NYBORG, H.; TULLIN, B. (1965). Heling processes after vital extirpation. An experimental study of 17 teeth. Odontologisk Tidskrift, Stockholm, v.73, p.430-444.

OGUCHI, H. et al. (1995). Long term histological evaluation og hydroxyapatite ceramics in humans. Biomaterial, Guildford, v.16, n.1, p.33-38.

ORBAN, B.; BHASKAR, S.N. (1978). Histologia e embriologia oral de Orban. 8.ed. São Paulo: Artes Médicas. 
OSAKA, A. et al. (1991). Calcium apatite prepared from calcium hydroxide and orthophosphoric acid. Journal Materials Science, Norwell, v.2, n.1, p.51-55, Jan.

PADILHA, A.F. (1997). Materiais de engenharia: microestrutura e propriedade. São Paulo: HEMUS. p.16-21.

PARK, J. (Ed.) (1984). Biomaterials science and engineering, New York: Plenum Press. p.1-10.

PARREIRA, D.R. (2004). Matrizes tridimensionais de colágeno aniônico:elastina como suporte para reconstrução de tecidos moles: um estudo da integração matriz/tecido. 56p. Dissertação (Mestrado) - Programa Interunidades em bioengenharia EESC/FMRP/IQSC, Universidade de São Paulo, São Carlos, 2004.

PASHLEY, D.H. (1985). Dentin-predentin complex and its permeability: physiologic overview. Journal of Dental Research, Chicago, v.64, p.613-620, Special Issue.

. (1988). Consideration of dentine permeability in cytotoxicity testing. International Endodontic Journal, London, v.21, p.143-148.

(1992). Mechanistic análisis of fluid distribution across the pulpodentin complex. Journal of Endodontics, Chicago, v.18, n.2, p.72-75.

PÉCORA J.D. (1990). Estudo de permeabilidade dentinária do assoalho de câmara pulpar dos molares inferiores humanos, com raízes separadas. Tese (Doutorado) Faculdade de Odontologia de Ribeirão Preto, Universidade de São Paulo, Ribeirão Preto, 1990.

PÉCORA J.D. et al. (2002). Análise quantitativa da presença de mercúrio em cápsulas de amálgama utilizadas. Robrac, v.11, p.27-29.

PEREIRA, J.C. et al. (1980). Efect of calcium hydroxide powder or in paste form on pulp-capping procedures: histopatologic and radiographic analysis in dogs' pulp. Oral surgery, Tokyo, v.50, p.176.

PFAFF, Ph. Apud CASTAGNOLA, L. (1956). La conservation de la vitalidad de la pulpa. Buenos Aires: Mundi. p.16.

PICOSSE, M. (1980). Anatomia dentária. [S.1.:s.n.]. p.1-10.

PITT FORD, T.R. (1985). Tissue reactions to two root canal sealers containing formaldehyde. Oral Surgery, Tokyo, v.60,p.661-65.

PITT FORD, T.R. et al. (1995). Use of mineral trioxide aggregate for repair of furcal perforations, Oral Surgery, Oral Medicine, Oral Pathology, and Radiology and Endodontics, St.Louis, v.79.

(1996). Using mineral trioxide aggregate as a pulp-capping material. Journal of Amedican Dental Association, Chicago, v.127, p.1491-1496.

PRIVALOV, P.I.; TIKTOPULO, E.I. (1970). Thermal conformational transformation of tropocollagen. I. calorimetric study. Biopolymers,New York, v.9, p.127-139.

PROKOP, A. (1997). Bioartificial organs sciences medicine and technology. Annals New York Academy of Sciences, New York, v.83, p.249-398. 
QUEIROZ, A.C. et al.(1997). Avaliação da habilidade seladora de alguns materiais retroobturadores. In: JORNADA ACADÊMICA DE ARAÇATUBA Prof.José Olívio Victor, 17., 1997, Araçatuba. Resumos... Araçatuba: FOA. v.18.

RADIN, S. et al. (1997). Calcium phospate ceramic coatings carries of vancomycine. Biomaterials, Guildford, v.18, n.11, p.777-782, June.

RAFTER, M. et al. (2002). Evaluation of healing with use of an internal matrix to repair furcation perforations. International Endodontics Journal, London, v.35, n.9, p.775-83.

RAMACHANDRAN, G.N. (1967). Treatise on collagen. London: Academic Press. v.1, p.337-353.

RAPPAPORT, L.; ABRAMSON, I.I. (1958). Aplication of steroid hormones in pulpcapping and pulpotomy procedures. Oral Surgery, Oral Medicine and Oral Pathology, St.Louis, v.11, p.545-48.

RAY, H.; SELTZER, S. (1991). A new glass ionomer root canal sealer. Journal of Endodontics, Chicago, v.17, n.12, p.598-603.

REIKER, J. Et al. (1999). A cross-sectional study into the prevalence of root caries in periodontal maintenance patients. Journal of Clinical Periodontology, Copenhagem, v.26, n.1, p.26-32, Jan.

ROCHA, L.B.; GOISSIS, G.; ROSSI, M.A. (2002). Biocompatibility of anionic collagen matrix as scaffold for bone healing. Biomaterials, Guildeford, v.23, p.449456.

ROLLING, I.; THYLSTRUP, A. (1975). A 3-year clinical follow-up study of pulpotomized primary molars treated with the Formocresol technique. Scandinmavian Dental Journal, v.83, p.47-53.

ROSA, F.P. et al. (2003). Tissue response to polyanionic collagen: elastin matrices implanted in rat calvária. Biomaterials, Guildford, v.24, p.207-212.

ROVIRA, A. et al. (1993). Preliminary reporty on a new composite material made of calcium phosphate, elastin peptides and collagens. Journal of Materials Science, Norwell, v.4, p.372-380.

RUCH, J.V. (1985). Odontoblast differentiation and the formation of the odontoblastic layer. Journal of Dental Research, Chicago, v.64, p.489-498. Special Issue

RUTHERFORD, R.B. et al. (1993). Induction of reparative dentine formation in monkeys by recombinant human osteogenic protein-1. Archives of Oral Biology, New York, v.38, p.571-576.

(1994). The time course of the induction of reparative dentine formation in monkeys by recombinant human osteogenic protein-1. Archives of Oral Biology, New York, v.39, n.10, p.833-838.

RYAN, J.A.; ZHANG, P. (1996). Soil lead remediation: is. removal the only opton? [S.1.]: US EPA Risk Reduction Engineering Laboratory.

SAAD, A.Y.; EGYPT, C. (1988). Calcium hydroxide and apexogenesis. Oral Surgery, Tokyo, v.66, n.4, p.499-501. 
SANTOS, H.S.; BARBOSA, S.V. (1992). Avaliação radiográfica de 2002 tratamentos endodônticos. Odonto, São Bernardo do Campo, v.1, n.5, p.149-154.

SAQUY, P.C.; PÉCORA, J.D. (1997). Orientação profissional em odontologia. São Paulo: Santos.

SCHIERHOLZ, J.M.; RUMP, A.; PULVERER, G. (1997). New antinfectious biomaterials. Ciprofloxacin containing polyurethanes as potencial drug delivery systems to prevent foreign-body infections. Arzeinem-Forsch, v.47, p.70-704.

SCHINDLER, W.G.; SCHWARTZ, S.A. (1989). Apical closure in the presence of pulpal necrosis: report of two cases. Journal of Endodontics, Chicago, v.15, n.11, p.555-558.

SCHUMACHER, J.W.; RUTLEDGER, R.E. (1993). An alternative to apexification. Journal of Endodontics, Chicago, v.19, n.10, p.529-531.

SCHWARTZ, R.S. (1999). MTA: a new material for endodontics. Journal of the American Dental Association, Chicago, v.130, p.967-975.

SELTZER, S.; BENDER, I.B.; TURKENKOPF, S. (1963). Factors affecting successful repair after root canal therapy. Journal of the American Dental Association, Chicago,v.67, p.651-662.

SELTZER, S. et al. (1967). Endodontic failures - an analysis based on clinical, roentgenographic, and histologic findings. Oral Surgery, Tokyo, v.23, n.4, p.500-516.

(1972). A scanning EM exam of Ag cones removed from endo treated teeth. Oral Surgery, Tokyo, v.33, p.589, Apr.

(1975). A polpa dental. 2.ed. Rio de Janeiro: Labor do Brasil.

SERRE, C.M. et al. (1993). In vitro induction of a calcifying matriz by biomaterials constituted of collagen and or hydroxyapatite: an ultrastrutural comparison of three types of biomaterials. Biomaterials, Guildford, v.14, n.2, p.97-106.

SHOVELTON, D.S. et al. (1971). The efficacy of pulp capping materials: a comparative trial. British Dental Journal, London, v.130, p.385-391.

SICHER, H. (1962). Orbam's oral histology and embriology. $5^{\text {th }}$ ed. St.Louis: C.V. Mosby.

SILVA, C.O.; BARBOSA, S.V.; FURTADO, W.W. (1994). Estudo in vitro da estabilidade dimensional, radiopacidade e solubilidade de três cimentos endodônticos à base de hidróxido de cálcio (Apexit, Sealapex e Sealer 26). In: ENCONTRO DE PESQUISADORES, 2., 1994. Anais... [S.1.]: UFGO. p.141.

SILVER, F.; DOILLON, C. (1989). Biocompatibility, interations and implantable materials. New York: VCR. v.1. 
SILVESTER, M.F.: YANNAS, I.V.; FORBES, M.J. (1989). Collagen banded fibril struture and the collagen platelet reaction. Thrombosis Research, New York, v.55, p.135-148.

SINAI, I. et al. (1967). Biologic aspects of endodontics. II - periapical tissue reactions to pulp extirpations. Oral Surgery, Tokyo, v.23, p.664-671.

SINGH, M.P. et al. (1995). The effect of electrostatic charge interactions on release rates of gentamicin from collagen matrices. Pharmaceutical Research, Hingham, v.12, p.1205-1210

SIQUEIRA JR., J.F.; FRAGA, R.C.; GARCIA, P.F. (1995). Evaluation of sealing ability, $\mathrm{pH}$ and flow rate of three calcium hydroxide-based sealers. Endodontics and Dental Traumatology, Copenhagem, v.11, p.225-228.

SOUZA, V.; HOLLAND, R. (1974). Treatment of the inflamed dental pulp. Australian Dental Journal, Sydney, v.19, p.191-196.

SJÖGREN, U. et al. (1990). Factors affecting the long-term results of endodontic treatment. Journal of Endodontics, Chicago, v.16, n.10, p.498-504.

ŚLÓSARCZYK A.; PASZKIEWICZ, S.; PALUSZKIEWICZ, C. (2005). FTIR and XRD evaluation of carbonated hydroxyapatite powders synthesized by wet methods. Journal of Molecular Structure, Amsterdam, v.744-747, p.657-661.

SMITH, J.W. (1968). Molecular pattern in native collagen. Nature, London, v.219, n.5150, p.157-163.

SPANGBERG, L.S.W.; BARBOSA, S.V.; LAVIGNE, G.D. (1993). AH26 releases formaldehyde. Journal of Endodontics, Chicago, v.19, n.12, p.596-598.

STEFFEN, H.; SPLIETH, C.H.; BEHR, K. (1999). Comparison of measurements obtained with hand files or the Canal Leader attached to electronic apex locators: an in vitro study. International Endodontic Journal, London, v.32, n.2, p.103-107, Mar.

STEGEMANN, H.H. \& STALDER, K. (1967). Determination of hydroxyproline. Clinica Chimica Acta, Amsterdam, v.18, p.267.

STEVEN, L.; GOODMAN, P.A.S.; ALBRECHT, R.M. (1996). Three-dimensional extracellular matrix textured biomaterials. Biomaterials, Guildford, v.17, p.2087-2095.

TABATA, Y. (2000). The importance of drug delivery systems in tissue engineering. Pharmaceutical Science \& Technology Today, v.3, p.80-89.

TEN CATE, A.R. (1985). Odontoblasts. Journal of Dental Research, Chicago, v.64, p.549-551. Special Issuae.

TORABINEJAD, M.; CHIVIAN, N. (1999). Clinical applications of mineral trioxide aggregate. Journal of Endodontics, Chicago, v.25, n.3, p.197-205, mar.

TORABINEJAD, M. et al. (1995). Physical and chemical properties of a new root-end filling material. Journal of Endodontics, Chicago, v.21, n.7, p.349-353. 
. (1995a). Comparative investigation of marginal Adaptation of mineral trioxide aggregate and other commonly used root-end filling material effects of blood contamination. Journal of Endodontics, Chicago, v.21, n.6, p.295-299.

TORNECK, C.D. (1970). Biologic effects of endontic procedures on developing incisor teeth. I - effect of partial and total pulp removal. Oral Surgery, Tokyo, v.30, p.258-66.

TSAI, T.-P.; SU, H.-L.; TSENG, L.-H. (1993). Glutaraldehyde preparations and pulpotomy in primary molars. Oral Surgery, Tokyo, v.76, p.346-350.

TRONSTAD, L.; BARNETT, F.; FLAX, M. (1988). Solubility and biocompatibility of calcium hydroxide containing root canal sealers. Endodontics and Dental Traumatology, Copenhagem, v.4, p.152-159.

TZIAFAS,D.; SMITH, A.J.; LESOT H. (2000). Designing new treatment strategies in vital pulp therapy. Journal of Dentistry, Chengtu, v.28, p.77-92.

. (2002). The dentinogenic effect of mineral trioxide aggregate (MTA) in short term capping experiments. International Endodontics journal, London, v.35, n.3, p.245-254, Mar.

VALDRIGHI, L.; HIZATUGU, R. (1973). Considerações sobre a biologia da polpa dental de interesse à Endodontia. Assoc. Paul. Cirurg. Dentistas., v.27, n.7, p.424446.

VAN VLACK, L.H. (1973). Princípio da ciência dos materiais. São Paulo:Edgard Blucher.

VEIS, A. (1982). Collagen fibrillogenesis. Connective Tissue Research, Philadelphia, v.10, n.1, p.11-24.

VERTUCCI, F.J.; WILLIAMS, R.G. (1974). Furcation canals in the human mandibular first molar. Oral Surgery, Tokyo, v.38,p.308, Aug.

VIDEAU, J.J.; DUPUIS, V. (1991). Phosphastes and biomaterials. European Journal of Solid State and Inorganic Chemistry, Montrouge, v.28, n.1, p.303-343.

VIIDIK, A.; VUUST, J. (1980). Biology of collagen. London: Academic Press. v.1, p.313-324.

VOTORANTIN-VOTORANTIN CIMENTOS (2005). Disponível em: $<$ http:/www.votorantin.com.br $>$. Acesso em: 10 abr.

WATTS, A.; PATERSON, R.C. (1983). Bacterial contamination and the toxicity of materials to the exposed pulp. Oral Surgery, Tokyo, v.56, n.5, p.542-548.

WEBBER, R.T. (1984). Apexogenesis versus apexification. Dental Clinics of North America, Philadelphia, v.28, n.4, p.669-697.

WEIDMANN G.; LEWIS P.; REID N. (1994). Structural materials. Oxford: Butterworth-Heinemann. 
WEIGER, R. et al. (1995). Adhesion of glass ionomer cement to human radicular dentine. Endodontics and Dental Traumatology, Copenhagem, v.11, p.214-219..

WELDON J. K. et al. (2002). Sealing ability of mineral trioxide aggregate and SuperEBA when used as furcation repair materials: a longitudinal study. Journal of Endodontics, Chicago, p.467-470.

WENDLAND, W.W.M. (1986). Thermal Analysis. $3^{\text {th }}$ ed. New York: John wiley. p.1-86.

WILLIAM, D.F. (Ed.). (1987). Definitions in biomaterials. New York: Elsever.

WINDHOLZ, M. et al. (1994). Merck index. $10^{\text {th }}$ ed. New Jerssey: Merck.

WHITE, R.A.; SHORS, E.C. (1986). Biomaterial aspects Interpore-200® porous hydroxyapatite. Dental Clinics of North American, Philadelphia, v.30, p.49-67.

WUCHERPFENNING, A.L.; GREEN, D.B. (1999). Trioxide vs Portland cement: two biocompatible filling materials. Journal of Endodontics, Chicago, v.25, n.4, p.308 (abstract PR40), Apr.

ZANDER, H.A. (1939). Reaction of the pulp to calcium hydroxide. Journal of Dental Research, Chicago, v.18, n.4, p.373-379.

ZANINI C.Z.; OGA S. (1985). Farmacologia aplicada. 3.ed. São Paulo: Atheneu. , p.466-485

ZHU, Q. et al. (2000). Adhesión of human osteoblasts on root end filling materials. Journal of Endodontics, Chicago, v.26, n.7, p.404-406, July. 


\section{GLOSSÁRIO}

Acidez - Característica d substância que apresenta pH menor que 7, teor ácido, acidificante.

Alergia - Conjunto de fenômenos de caráter respiratório, nervoso e eruptivo causados por certos agentes físicos, químicos ou biológicos que promovem, no organismo, sensibilidade especial diante de nova ação de tais agentes, mesmo que em quantidades mínimas. Estado de hipersensibilidade adquirido por meio de exposição a alérgeno especifico. Tipo de reação antígeno-anticorpo caracterizada pr suscetibilidade exagerada a substância normalmente inócua em quantidade similar para a maioria dos membros da mesma espécie.

Assepsia - Anti-sepsia profilática. Conjunto de meios ou processos para afastar do organismo os agentes da infecção. Processo pelo qual se consegue afastar os germes patogênicos em determinado local ou objeto.

Antimicrobiano - Agente que previne infecções ou as combate, impedindo a proliferação de microrganismos matando-os.

Apecificação - Indução da complementação, ou do fechamento apical de dente com raiz incompleta formada e onde e onde a polpa se apresenta necrosada. Normalmente, o processo se faz às expensas de tecido duro tipo osteocementóide.

Apexogênese - Formação fisiológica da parte radicular de dente, que pode ser auxiliada por pulpotomia.

Ápice dental - Termo aplicado à extremidade da raiz.

Bacteremia - Presença de bactéria na corrente sangüínea, sem proliferação. Estado normalmente transitório.

Bifurcação - Área de dente birradiculado na qual as raízes começam a se dividir. Ato de bifurcar, separar em dois. polpa viva.

Biopulpectomia - Procedimento endodôntico que consiste na remoção da polpa.

Câmara pulpar - Parte interna do dente formada por dentina que circunda a

Canal - Cavidade estreita e mais ou menos alongada, tubular, destinada a dar passagem aos líquidos ou gases, ou ainda a alojar determinados órgãos. Chamado também de conduto, principalmente na literatura espanhola. No caso do dente, considera-se canal mais correto, pois este abriga a polpa dental, enquanto conduto é o que serve de passagem para líquidos, não abrigando nenhum órgão. O canal radicular, normalmente não serve para veiculação de fluidos ou gases.

Canal acessório - Ramo ou bifurcação do canal principal, normalmente localizado no terço apical de uma raiz, que comunica o canal principal com o periodonto.

Canal divergente - Termo usado para definir o canal de uma raiz parcialmente formada, no qual o diâmetro apical é maior que o cervical. Chamado de "blunderbuss", na literatura inglesa.

Canal lateral - Ramo ou bifurcação do canal principal, normalmente localizado no terço médio e cervical de uma raiz, que comunica o canal principal com o periodonto.

Canal radicular - Cavidade interna da raiz de um dente. Estende-se da junção cemento-esmalte até a junção cemento-dentina, no ápice radicular.

Capeamento pulpar - Procedimento no qual a polpa exposta ou quase exposta é coberta com curativo ou cimento que a protege de traumas adicionais, dando 
condições ao reparo. Denomina-se capeamento direto quando o curativo e colocado diretamente sobre a polpa exposta. Capeamento indireto, quando o medicamento é colocado sobre a parte mais delgada da dentina.

Cavidade pulpar - Espaço interno do dente, normalmente ocupado pela polpa. Também é chamada de câmara pulpar.

Dentina - Tecido mineralizado localizado na parte interna do dente, abaixo do esmalte ou do cemento, circundando a polpa coronária e radicular. Sua composição é aproximadamente $70 \%$ inorgânica, 20\% orgânica e 10\% água.

Dentina esclerótica ou transparente - Dentina na qual os túbulos dentinários são obliterados por sais de cálcio.

Dentina interglobular - Áreas pouco ou não mineralizadas da dentina, encontradas primariamente na coroa, perto da junção esmalte-dentina.

Dentina intertubular - Matriz de dentina calcificada, externa a dentina peritubular e que constitui o corpo dentinário.

Dentina peritubular - Estreita faixa de dentina ao redor do processo odontoblástico e que define o canalículo dentinário, sendo muito calcificada.

Dentina reparativa (irregular, secundária, irritacional, reacional, terciária ou osteodentina) - É a dentina produzida em resposta à irritação intensa, como cárie profunda, restaurações extensas, etc. Forma-se na área subjacente à zona de irritação que apresenta canalículos dentinários tortuosos, mineralização irregular e, eventualmente, inclusões celulares.

Dentina tubular - Dentina regular ou também pré-dentina que contém túbulos dentinários.

Descalcificação - Remoção de cálcio ou sais de cálcio do osso ou dos dentes.

Estandardização dos instrumentos - Classificação adotada na confecção dos instrumentos endodônticos. Segue as normas definidas pelo American National Standars institute (ANSI) ou a International Standars Oganization (I S O), normalmente apoiadas pela American Dental Association (ADA), nos Estados Unidos.

Esterilidade - Estado que denota ausência de qualquer forma de vida. Comumente se refere à ausência de microrganismos e esporos.

Esterilização - Método capaz de destruir qualquer forma de vida.

Esterilização em autoclave ou em calor úmido - Método seguro de esterilização que usa calor úmido sob pressão, dentro da câmara. O tempo e a temperatura, usualmente recomendados são 15 minutos a $121^{\circ} \mathrm{C}$ no mínimo.

Esterilização com calor seco ou estufa - Método de esterilização que usa o calor seco dentro de um tipo de estufa. O tempo é de 1 hora a $180^{\circ} \mathrm{C}$ ou a 2 horas a $160^{\circ} \mathrm{C}$.

Eugenol - Componente fenólico com propriedades anti-sépticas e anódinas, obtido da essência do cravo. Combina-se facilmente com o óxido de zinco, formando diversos cimentos de uso comum em odontologia. É às vezes, usado como medicamento intracanal.

Exposição pulpar - Abertura na camada dentinária que envolve a polpa. Pode ser por cárie ou acidentalmente feita pelo profissional ou, ainda, por traumatismo dental.

Fagocitose - Processo que consiste no englobamento, por fagócitos, de corpos estranhos, células mortas e microrganismos.

Fibroblastos - Representam a maioria das células existentes na polpa, sendo encontrada em toda estrutura. Produzem matriz gelatinóide, onde os demais elementos pulpares encontram-se imersos. Além da matriz, os fibroblastos formam também fibras elásticas e colágenas. 
Fibrose pulpar - Aumento em número e tamanho dos elementos fibrosos da polpa, com diminuição do número de células. Pode ser decorrente da idade ou de alterações degenerativas na polpa.

Forame - Abertura ou passagem através de tecido duro.

Formocresol - Mistura de 19\% de folmaldeído e 35\% de cresóis em meio que contém glicerina e água. É usado em pulpotomia de dentes decíduos, de acordo com técnica específica.

Hidróxido de cálcio $\left(\mathrm{CaOH}_{2}\right)$ - Pó branco, sem odor, solúvel em água. Não apresenta solubilidade apreciável em outros líquidos. Soluções aquosas ou não aquosas de hidróxido de cálcio têm sido usadas freqüentemente como protetores pulpares em capeamento, pulpotomia, apexogênese e apecificação.

Histiócitos - Representam os macrófagos teciduais responsáveis pela defesa tissular. Durante processos inflamatórios fagocitam células, bactérias e materiais estranhos.

Iatrogenia - Estado anormal, causado acidentalmente pelo profissional durante procedimento médico-odontológico incorreto.

Implante - Qualquer material inserido dentro dos tecidos.

Inflamação - Processo mórbido ou alteração anormal de tecidos ou órgãos causada por injuria ou destruição tecidual, produzindo sinais e sintomas locais: calor, rubor, dor e perda de função. Inflamação pode ou não resultar de infecções.

Linfocitos e plasmocitos - Células de defesa que podem ser vistas na camada subodontoblástica. Representam as células imunocompetentes.

Mastócitos - São células normalmente encontradas em polpas inflamadas, têm funções de defesa atuando na permeabilidade vascular pela ação dos grânulos com histamina, propiciando condições para a inflamação e posterior reparo.

Necrose - Morte de uma ou de um grupo de células.

Necrose pulpar - Morte da polpa dental.

Odontoblasto ou dentinoblasto - Célula do tecido conjuntivo, altamente diferenciada, formadora de dentina, encontrada na parte externa da polpa, em contato com a pré-dentina.

Osteodentina - Nome dado a um tipo de dentina reparador.

Polpa dental - Tecido conjuntivo ricamente vascularizado e inervado, que preenche o espaço interno da cavidade pulpar.

Ponte dentinária - Depósito de tecido duro sobre parte injuriada da polpa, promovendo o fechamento desta. Pode ser observada radiograficamente após pulpotomia.

Pulpotomia - Amputação cirúrgica da parte coronária de polpa vital, que visa preservar a vitalidade e função da porção radicular. Indicada em polpas vitais de dentes decíduos e em dentes com raízes parcialmente formadas. Pode ser também procedimento de urgência, antes do tratamento endodôntico.

Quelação - Implica na remoção de íons divalentes positivos, sendo, em Endodontia, normalmente, o cálcio. Os íons são removidos da estrutura dentária por agente químico, que se combina com estes íons, formando quelato de cálcio. Um agente bastante usado para tal fim é o EDTA. A quelação ajuda, às vezes, a alargar canais radiculares estreitos. dos raios $\mathrm{X}$.

Radiopacidade - densidade aumentada, que denota resistência a penetração

Teste pulpar - Procedimento diagnóstico para verificar a vitalidade ou anormalidade pulpar, por meio de testes elétricos ou pela aplicação de calor e fria. 